MARCOS DA FONSECA NOGUEIRA

\title{
O PRINCÍPIO DA MORALIDADE NA ADMINISTRAÇÃO TRIBUTÁRIA
}

\begin{abstract}
Dissertação de Mestrado apresentada à Faculdade de Direito da Universidade de São Paulo, como requisito parcial para a obtenção do título de Mestre em Direito Econômico e Financeiro, sob a orientação do Professor Doutor Gerd Willi Rothmann
\end{abstract}

Universidade de São Paulo

Faculdade de Direito

São Paulo

2010 
A Deus,

por tudo,

ontem, hoje e sempre. 
Agradecimentos:

Ao

Prof. Dr. Gerd Willi Rothmann, pelo apoio e orientações

dadas no decorrer deste trabalho.

Ao

Prof. Dr. Alcides Jorge Costa, pela amizade e incentivo neste início de carreira.

$\grave{A}$

Prof. Dra. Denise Poiani Delboni, pela ilustre presença neste importante momento de minha vida profissional. 


\section{RESUMO}

A construção de uma sociedade livre, justa e solidária, capaz de promover o bem comum, indistintamente, assim como a erradicação da pobreza e da marginalidade, além da redução da desigualdade social, são objetivos de nossa República, e com certeza, vontade de quase todos os brasileiros.

Isto significa que as ações do Estado têm que ser realizadas visando a concretização

de uma justiça social. É para isto que deve estar a serviço o Estado, e é para corroborar com o alcance desta finalidade, que contribuímos por meio dos tributos que pagamos.

O tributo advém de uma obrigatoriedade social, que ocasiona a saída do dinheiro da esfera particular e passa a integrar o que conhecemos por recurso público, o qual será administrado pelo Estado, através dos seus agentes estatais. Estes devem gerenciar e empenhar este recurso, única e exclusivamente para cumprir os fins sociais, para o que a honestidade e a probidade são exigências irrenunciáveis.

Para ofertar esta garantia é que se presta o princípio da moralidade, o qual está na centralidade de nosso trabalho. Na prática, devido a nossa tradição positivista e a nossa cultura patrimonialista, observamos a dificuldade em se lidar com a moralidade no interior do Direito e especialmente na administração do recurso fruto do esforço coletivo.

A consignação do princípio da moralidade em nossa Constituição, faz com que a sua observância seja obrigatória no manejo da coisa pública, sendo que a mínima suspeita sobre o seu desrespeito pode e deve ser judicialmente controlado. Para isto é imprescindível que se aprimore cada vez mais os mecanismos de controle.

A sociedade civil tem um papel fundamental neste exercício democrático, e para isto, formas dialógicas e interativas entre os cidadãos e o Estado têm que ser constantemente aperfeiçoadas, pois, se a imoralidade na administração tributária favorece somente alguns, a moralidade, por sua vez, vem atender aos interesses da maioria da população. 


\begin{abstract}
The construction of a free, fair and solidary society, capable of promoting the common good, indistinctly, such as the eradication of poverty and crime, as well as the decrease in social inequality, are the objectives of our Republic, and without a doubt, the will of nearly all Brazilians.
\end{abstract}

This means that the actions of the State must be executed, bearing in mind the effective implementation of a social justice. This is the role of the State, and it is in order to corroborate within the means of this end that we contribute as taxpayers.

Taxes derive from a social obligation in which money leaves the personal sphere and becomes part of what is known as a public resource, which will be administered by the State via its government agents. These agents must manage and make effective use of this public resource, solely and exclusively for the purpose of accomplishing social means, in order for honesty and integrity to be fundamental requirements.

This guarantee is ensured by the principal of morality, which is found at the core of our work. In practice, due to our positive law tradition and our patrimonial culture, we observe the difficulty in dealing with morality inside the Law and mainly in the administration of resources which are the product of public efforts.

The consignment of the principal of morality in our Constitution makes its observance mandatory in the dealings of public affairs, since a minimal suspicion about its nonobservance may and should be judicially controlled. In order to accomplish this, it is of utmost importance that the control mechanisms are improved continuously.

Civil society has a fundamental role in this democratic exercise and therefore, interactive and conversational forms among citizens and the State must be perfected constantly. For, if immorality in the tax administration favors only a few, morality, in its turn, serves the interests of the majority of the population. 


\section{SUMÁRIO}

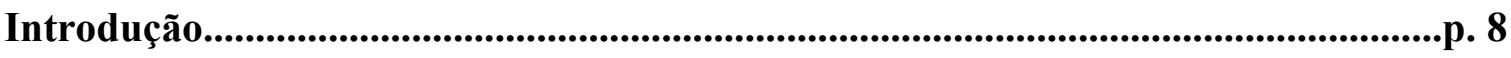

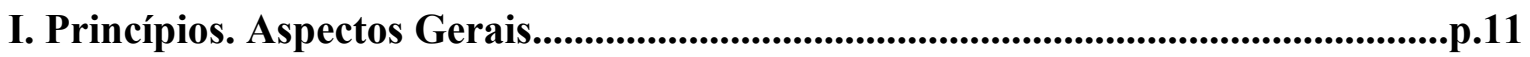

II. Recurso Público e sua Administração...............................................................................p. 14

III. Princípios Constitucionais Norteadores da Administração Tributária...............p.17

3.1 Princípio da Legalidade....................................................................................p. 17

3.2 Princípio da Impessoalidade.........................................................................................p. 21

3.3 Princípio da Publicidade.......................................................................................... 23

3.4 Princípio da Eficiência........................................................................................................p. 27

IV. A Moralidade como Princípio Norteador da Administração Pública.................p. 29

4.1 Antecedentes Históricos da Moralidade Administrativa....................................p. 29

4.2 A Evolução do Conceito e do Instituto no Brasil.......................................................p. 35

4.3 Análise da Moralidade na Constituição Federal.......................................................p. 43

4.4 Alcance e Conteúdo da Moralidade na Administração Tributária.....................p. 51

V. Princípios Vinculados à Moralidade Administrativa............................................p. 59

5.1 Princípio da Boa-fé.....................................................................................................................p. 60

5.2 Princípio da Vedação do Comportamento Contraditório.......................................p. 62

5.3 Princípio da Probidade Administrativa................................................................p. 65

5.4 Princípio da Proporcionalidade........................................................................p. 68 
5.5 Princípio da Razoabilidade.

..p. 71

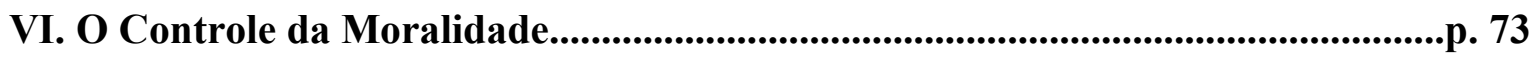

6.1 Mecanismos de Controle Interno e Externo................................................................p. 74

6.2 Tribunal de Contas........................................................................................p. 77

6.3 Controle Social..............................................................................................................p. 81

6.4 Controle Judicial...................................................................................................................p. 84

6.4.1 Ação Popular...............................................................................................................p. 84

6.4.2 Ação Civil Pública.........................................................................................p. 85

VII. A Responsabilidade do Estado pela Transgressão ao Princípio da Moralidade p. 87

7.1 Regime Jurídico Brasileiro...............................................................................p. 87

7.1.1 Causas Excludentes e Atenuantes de Responsabilidade................................p. 89

7.1.2 Reparação do Dano.....................................................................................................p. 90

7.2 Responsabilidade do Servidor Público......................................................................p. 91

92

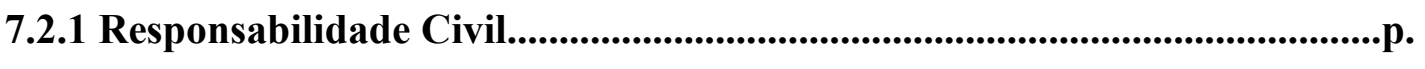

7.2.2 Responsabilidade Penal...........................................................................................p. 94

7.2.3 Responsabilidade Administrativa.............................................................. 95

7.2.4 Comunicabilidade de Instâncias.................................................................p. 96

VIII. Conclusões...............................................................................................................p. 99

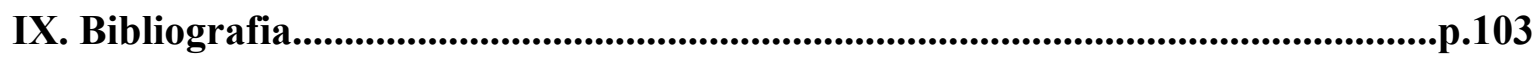




\section{INTRODUÇÃO}

O presente trabalho se propõe a analisar algo que pela primeira vez em nossa história foi inserido em uma Constituição: a moralidade administrativa.

Em tempos onde a falta de ética e a desonestidade generalizada imperam, entendemos ser essencial dar voz a um princípio que não foi alocado em nossa Carta Constitucional por um acaso, pelo contrário, nos parece que fincar a bandeira da moralidade na Administração Pública foi algo intencional e estrategicamente realizado por nosso legislador constituinte.

No ano de 1988, depois de ser travada uma árdua luta social, foi possível firmar, constitucionalmente no Brasil, um Estado Democrático de Direito. É cediço, no entanto, que a sua implementação não é instantânea, sendo a sua constitucionalização apenas o início de um longo processo, cuja viabilização principal dar-se-á por intermédio do Estado, nos três níveis da federação, o qual, utilizando-se dos frutos da arrecadação tributária, deverá conduzir suas ações no sentido de se alcançar os objetivos e metas previstos constitucionalmente, promovendo-se, então, social, cultural e economicamente a nação brasileira.

Neste cenário de transição da sociedade, o agente público torna-se um ser especial e essencialmente importante. Justamente por tal razão é que o desempenho das atividades dos agentes públicos tem que se dar da forma mais ética e harmônica possível, e para tal, houve a estipulação constitucional de alguns princípios básicos, dispostos no art. 37 da Constituição, que deverão ser as "guias mestras" de suas ações.

Por outro lado, esta realização social e democrática somente será alcançada, caso o recurso público seja adequadamente empenhado, para o que, dentre outras coisas, não podemos tolerar desvios, sendo que seu uso não deverá servir para fins outros que não os socialmente delineados, ou seja, o uso imoral da coisa pública tem que ser podado a cada 
dia do ambiente estatal. Eis a principal preocupação de nosso trabalho: a moralidade no trato com o orçamento e as finanças públicas.

Para o desenvolvimento de nossa inicial preocupação, começamos por um estudo da principiologia, diferençando princípios de regras no sentido de afirmar a superioridade principiológica sobre qualquer norma infra-constitucional.

Em seguida, faremos uma breve exposição acerca da origem e dos objetivos dos recursos públicos, afirmando que ele advém do esforço coletivo do povo e é para ele que deve necessariamente ser revertido, sendo certo que, qualquer desvio deste direcionamento social, apontará sérios indícios de imoralidade.

Para melhor entendimento dos princípios norteadores da atividade administrativa, faremos análise de cada um deles separadamente, mas, sempre buscando relacioná-los com o nosso foco principal, ou seja, a questão da moralidade no manejo dos recursos públicos.

Após tal exame, será destinado um capítulo especial para a moralidade, onde traremos uma retrospectiva histórica do desenvolvimento do conceito e do instituto da moralidade administrativa. Nos ateremos depois, a tratá-la em consonância com a nossa Constituição, verificando o reflexo deste princípio, na prática administrativa ao se gerenciar e empregar a receita pública.

Em seguida, discorreremos brevemente sobre outros princípios que, embora não estejam expressamente previstos no texto constitucional, são decorrentes de sua lógica sistemática, além de fundamentais ao entendimento global do que vem a ser a moralidade administrativa.

Uma vez examinados tais princípios, passaremos, então, ao conhecimento dos mecanismos de controle para se promover o controle da moralidade, partindo-se da perspectiva de que será mais benéfico socialmente prevenir o mau uso do dinheiro público do remediar a sua malversação, e neste sentido, um caminho que devemos constantemente visualizar é do fomento radical da transparência das contas e dos gastos públicos.

Esta democrática transparência quantitativa e qualitativa da elaboração e execução dos gastos públicos, deve ser permanentemente aprimorada, inclusive, para garantia do 
exercício da democracia, assim como estabelecido no parágrafo único, do artigo $1^{\circ}$, da Constituição Federal.

Por fim, consignamos que a imoralidade perpetrada por um agente, ao se desviar um recurso público de sua genuína finalidade, não pode ser visto como algo natural, pelo contrário, deve ser entendida como uma séria e deletéria disfunção social, que precisa ser urgentemente consertada, e, para tanto, iremos analisar as formas de se promover a responsabilização dos agentes, que na condição de representantes diretos ou indiretos do Estado, venham a transgredir o princípio ora estudado.

Sem a pretensão de esgotar a matéria, esperamos que esta dissertação possa contribuir para uma melhor compreensão da importância do princípio da moralidade, entendendo melhor o seu alcance social, visando o constante aprimoramento estatal, para dificultar cada vez mais o mau e vil uso do dinheiro que é de todos nós. 


\section{PRINCÍPIOS. ASPECTOS GERAIS}

De acordo com Miguel Reale, princípios são "verdades ou juízos fundamentais, que servem de alicerce ou de garantia de certeza a um conjunto de juízos, ordenados em um sistema de conceitos relativos a dada porção da realidade" .

Os princípios devem ser empregados quando não houver uma norma específica, nos casos de lacuna legislativa ou do costume ${ }^{2}$.

$\mathrm{Na}$ visão de Robert Alexy, princípios são "mandatos de otimização" e não se aplicam de forma disjuntiva, como as regras, exigindo ponderação caso colidam com uma situação concreta ${ }^{3}$.

Por isso o Direito não pode ser compreendido apenas como um conjunto de preceitos. Deve ser entendido também, pela reunião complexa de normas e princípios que se interagem, com observância, logicamente, ao sistema jurídico como um todo, e principalmente a hierarquia.

Ademais, os princípios representam, também, a função de interpretar o mundo jurídico como um todo, dando sentido e harmonia a ele. ${ }^{4}$

\footnotetext{
${ }^{1}$ Conceito antigo, porém atual. (REALE, Miguel. Filosofia do Direito. $1^{\mathrm{o}}$ vol., $5^{\mathrm{a}}$ ed. São Paulo: Saraiva, 1969, p. 54).

${ }^{2}$ Apesar de consultada a $3^{\text {a }}$ edição (2007) desta obra, utilizamos-nos da $1^{\text {a }}$ edição para chamar a atenção do leitor para o tema, que sempre foi objeto de discussões, inclusive na doutrina pátria, e no qual não iremos nos aprofundar (BANDEIRA DE MELLO, Oswaldo Aranha. Princípios Gerais de Direito Administrativo. $1^{\circ}$ vol., $1^{a}$ ed., Rio de Janeiro: Forense , 1969, p. 361).

${ }^{3}$ Os princípios não exigem tratamento rígido para aplicá-los (ALEXY, Robert. Derecho y razon práctica. México: Biblioteca de Ética, Filosofia del Derecho y Política, 1998, p. 9).

${ }^{4}$ Para o jurista Norberto Bobbio, além da função interpretativa, o princípio ainda possui outras três características): "Nello sguardo più ampio che abbiamo cercato di dare sin qui all’impiego general, si possono distinguere quattro funzioni: interpretativa; integrativa; direttiva e limitativa". (Principi generali di Diritto. Novissimo digesto italiano. Terza Edizione/Vnione Tipografico - Editrice. Torinese: 1957, p. 8956.).
} 
Assim, como as normas são analisadas segundo a pirâmide kelseniana, os princípios, também, o são. Existem princípios constitucionais, legais e infralegais.

Dentre eles, os princípios jurídico-constitucionais são os mais relevantes, uma vez que norteiam a atuação de todas as normas jurídicas, restringindo seus alcances e conteúdos 5 .

Os princípios arraigados na Constituição Federal não são mais vistos como princípios simplesmente científicos. Transformaram-se em direito positivo, com real eficácia normativa, possuindo, ainda, incidência obrigatória, seja na esfera constitucional ou infraconstitucional ${ }^{6}$.

Em tal cenário, os princípios devem ser empregados quando houver incerteza, mas, pelo fato dos valores da sociedade sofrerem alterações com o passar do tempo, suas aplicações podem restar prejudicadas. E mais, havendo previsão legal, os princípios não devem ser colocados em prática, sob pena de comprometer a unicidade do sistema jurídico.

Destacamos, ainda, que os princípios constitucionais são o ápice do sistema jurídico; são concretizados a partir das normas que os regulamentam, e, por sua vez são aplicados conforme cada ciência.

Como defende José Cretella Neto, “toda e qualquer ciência está alicerçada em princípios que são proposições básicas, fundamentais e típicas, as quais condicionam as estruturas e desenvolvimento subseqüente dessa ciência"7.

Em síntese, quer sob o aspecto constitucional, quer sob o da ciência do Direito, percebe-se que, se todo o poder emana do povo (artigo $1^{\circ}$, parágrafo único, da Constituição

\footnotetext{
${ }^{5}$ A Constituição é aqui entendida num sentido material, ou seja, significa a norma positiva ou as normas positivas pelas quais regula-se a produção das normas jurídicas gerais" (KELSEN, Hans. Teoria pura do direito. Tradução de João Baptista Machado. $5^{\mathrm{a}}$ ed. Coimbra: Armênico Amado, Editor, 1979, p. 309-10).

${ }^{6}$ Humberto Ávila classifica a eficácia dos princípios, precipuamente, como interna e externa. Enquanto a eficácia interna atua sobre as normas jurídicas, para compreensão de outras normas; a eficácia externa põe em ação as normas jurídicas, para interpretação dos fatos externos. Teoria dos Princípios da definição à aplicação dos princípios jurídicos. $6^{\mathrm{a}}$ ed. São Paulo: Malheiros, 2006, p. 97-112.

${ }^{7}$ CRETELLA NETO, José. Fundamentos Principiológicos do Processo Civil. Rio de Janeiro: Forense, 2002, p. 4 (itálico do original).
} 
Federal), e os princípios espelham sua vontade, não só as leis, mas também os princípios, refletem as escolhas da sociedade.

De outra parte, Jorge Miranda assevera que: “Os princípios não se colocam, pois, além ou acima do Direito (ou do próprio Direito positivo); também eles numa visão ampla, superadora de concepções positivistas, literalistas e absolutizantes das fontes legais, fazem parte do complexo ordenamental"».

Resta claro, portanto que a vontade do agente público não pode se sobrepor às necessidades e desejos dos cidadãos. Suas intenções não podem existir livremente dissociadas do bem comum.

Afinal, como bem observa Humberto Ávila: "Constituem, pois, violação ao princípio da moralidade a conduta adotada sem parâmetros objetivos e baseada na vontade individual do agente e o ato praticado sem a consideração da expectativa criada pela Administração" .

Como veremos adiante, pela análise dos princípios expostos a seguir, principalmente pelo princípio da moralidade, é justamente estas escolhas, intenções e vontades, que podem prejudicar o desenvolvimento de uma nação, ou, quem sabe, alterar e melhorar, sua realidade social.

\footnotetext{
${ }^{8}$ MIRANDA, Jorge. Manual de direito constitucional. $3^{\text {a }}$ ed. Coimbra: Coimbra Editora, 1996, t. II, p. 224-5.
}

${ }^{9}$ ÁVILA, Humberto, op. cit., p. 96. 


\section{RECURSO PÚBLICO E SUA ADMINISTRAÇÃO}

Inicialmente, diante da estreita relação entre administração do recurso público e a moralidade, traremos uma noção sobre o que é, como se forma e a que se destina o recurso público.

O recurso público forma-se a partir da contribuição obrigatória de todos os cidadãos-consumidores inseridos em dado Estado; esta contribuição recebe o nome de tributos e a sua obrigatoriedade é evidente uma vez que não se trata de um ato volitivo, ou seja, não há margem para o cidadão escolher se paga ou não determinado tributo.

Devemos lembrar que, em tudo que consumimos, está embutido o valor de um ou mais tributos. Um simples olhar para nosso cotidiano nos leva a perceber o quanto contribuímos para a formação do dinheiro público.

Para o pão e a manteiga dispostos pela manhã na mesa dos brasileiros já foram pagos os respectivos impostos. Para irmos até o nosso trabalho pegamos o ônibus, no qual também há imposto embutido; se formos de carro, já houve uma série de impostos e continuaremos todo o ano a pagar imposto sobre o automóvel, e toda vez em que abastecermos, sobre o combustível. Em casa, pagamos tributos sobre a energia elétrica utilizada, a água consumida, o gás que usamos no preparo dos alimentos, sobre cada ligação telefônica que realizamos, enfim, há incidência de tributos sobre todos os bens que adquirimos e sobre todos os serviços que utilizamos diariamente.

É de se lembrar que o brasileiro, em média, trabalha de janeiro a maio somente para pagar tributos. Isto significa que dos 365 dias do ano, 148 dias, em média, são de trabalhos dedicados a pagar impostos, taxas e contribuições. Queremos com isso afirmar que todos nós, ainda que inconscientemente, acabamos por contribuir com a formação do recurso público. E é justamente por ser este um recurso formado e constituído a partir da contribuição de todos os agentes inseridos em dada sociedade, que a sua reversão deve se 
dar inafastavelmente em prol do desenvolvimento e da melhoria de condições de vida desta mesma sociedade contribuinte.

Todo este recurso, como sabemos, é direcionado e arrecadado pelo Estado, mas a que serve? Como e com qual objetivo deve-se utilizar este recurso?

Neste trabalho temos a perspectiva de que o objetivo e o sentido do Estado têm que se desenvolver para atenderem os interesses públicos, legitimamente definidos, indicados ou delineados em nosso instrumento normativo maior, ou seja, a Constituição Federal. São as normas ali inseridas que indicam o caminho a ser perseguido pelo Estado e pela sociedade. É o corpo constitucional que traça os objetivos gerais buscados, os quais deverão tangenciar e nortear as decisões advindas do Estado.

Embora a observância global da Constituição seja necessária, faremos aqui um recorte em algumas normas que, a nosso ver, traçam os objetivos fundamentais do Estado nacional, estando dispostas nos artigos $1^{\circ}, 3^{\circ}, 4^{\circ}, 5^{\circ}, 170$ e 193.

A Constituição Federal, logo em seu Título I, estipula os Princípios Fundamentais da República Federativa do Brasil, dando o direcionamento político das ações do Estado Nacional, afirmando, a partir da redação do art. $3^{\circ}$, os seus objetivos fundamentais. Assim, o diretivo constitucional colocado às ações do Estado está no sentido de se construir uma sociedade livre, justa e solidária, de garantir o desenvolvimento nacional, além de dever concentrar esforços no intuito de erradicar a pobreza e a marginalização, reduzindo as desigualdades sociais e regionais, visando a promover o bem de todos, sem preconceitos de origem, raça, sexo, cor, idade e quaisquer formas de discriminação. Reside aí motivação fundante da criterização para utilização do recurso público. O direcionamento e o empenho do recurso público somente serão lícitos, portanto, se forem guiados e se estiverem em busca do cumprimento de tais objetivos.

Assim, a simples afirmação de que o montante da arrecadação tributária consiste em um recurso de caráter eminentemente público traz uma série de implicações no que diz respeito à forma e a como será aplicado e administrado este montante, seja por quem for. 
É neste sentido que se desenvolve a preocupação de nosso trabalho e é com este espírito que viemos aqui reafirmar a necessidade da probidade e da transparência no manuseio destes recursos, pois sem alguns cuidados mínimos essenciais, veremos os objetivos descritos no artigo $3^{\circ}$ da Constituição bem distantes de serem alcançados.

Compartilhando destas mesmas preocupações, o legislador constituinte traçou as diretrizes para a Organização do Estado no Título III da Constituição da República Federativa do Brasil, consagrando em seu Capítulo VII, as normas regentes básicas da Administração Pública, direta e indireta, de qualquer dos Poderes da União, dos Estados, do Distrito Federal e dos Municípios, trazendo explicitamente no caput do art. 37, cinco princípios que devem ser necessariamente obedecidos, os quais primordialmente visam a garantir, estruturar e consolidar o próprio Estado Democrático de Direito, o que, conseqüentemente, acaba por firmar a probidade e a transparência na gestão da coisa pública, e por possibilitar a responsabilização dos agentes públicos que se afastarem destas diretrizes obrigatórias e constitucionalmente estabelecidas.

Devemos destacar que o respeito principiológico trazido com a redação do art. 37 da CF deve ser observado por qualquer um dos Poderes, e em todos os entes da federação, não somente pela Administração Pública direta, mas também por aqueles que indiretamente perceberem e realizarem a administração de recurso público de qualquer natureza.

Assim, o art. 37 preceitua a obrigatoriedade da observância e respeito aos princípios da legalidade, impessoalidade, publicidade, eficiência e moralidade.

Nesta toada, são estes princípios também especialmente norteadores e somente com o seu respeito é que se estará garantindo a legitimidade na administração tributária. Relegálos é desvirtuar a gestão dos negócios públicos e olvidar o que há de mais elementar para a boa guarda e zelo dos interesses sociais. 


\section{PRINCÍPIOS CONSTITUCIONAIS NORTEADORES DA ADMINISTRAÇÃO TRIBUTÁRIA}

Passaremos, então, à compreensão de cada um desses princípios, sendo que trataremos o princípio da moralidade em tópico apartado a este, por merecer este princípio, no âmbito do presente trabalho, um destaque e tratamento especial.

Devemos destacar que o princípio da moralidade, especialmente quando observamos na prática a sua ofensa, embora façamos a defesa de sua autonomia, pode, em menor ou maior medida, vir relacionado com cada um desses princípios descritos no art. 37. Ainda assim, mesmo que sejam eles inconfundíveis entre si, poderá haver dúvida na sua aplicação. Por tal razão, entendemos por analisar o entendimento global dos princípios que norteiam as decisões e os atos administrativos e, por consequência, a administração dos recursos públicos.

\subsection{Princípio da Legalidade}

É o princípio da legalidade que traz o fundamento a toda e qualquer atividade administrativa da Administração Pública, sendo ele, neste sentido, o ponto de partida dos demais princípios, que irão, conseqüentemente, esclarecer e se guiarem pela legalidade posta.

Sabemos que a seara privada é determinada pela liberdade do ser humano, que pode fazer tudo aquilo que não contrarie a lei, assim, a legalidade é colocada como uma restrição à liberdade individual. Por outro lado, em relação à seara pública, a lei serve para dar a diretriz e a permissividade daquilo que se pode fazer. Neste sentido, o agente público deve sujeitar-se à legalidade, uma vez que é lícito fazer somente aquilo que está delineado nos regramentos e nos princípios legitimamente constituídos, inexistindo incidência de sua 
vontade meramente subjetiva, sendo-lhe vedado fazer aquilo que não estiver previamente normatizado.

Assim, o princípio da legalidade impõe à Administração Pública a necessidade de autorização legal justificante tanto das ações quanto das omissões dos agentes estatais. Trata-se este princípio de uma decorrência do estabelecimento do Estado nacional como um Estado Democrático de Direito, isto porque os atos da Administração Pública servem única e exclusivamente para realizarem diretamente e espelharem indiretamente a vontade de um povo, refletida a partir do que está democraticamente normatizado.

Ademais, devemos destacar que a normatização da atividade estatal não se exaure com a legalidade formal, já que esta deve ser combinada e subsidiada com a vedação de editar atos ou tomar medidas - ainda que legais - que contrariem as normas do ordenamento jurídico vigente, com destaque aquelas constitucionalmente previstas.

Por esta razão alguns doutrinadores defendem a inevitável substituição do princípio da legalidade pelo princípio da juridicidade, o qual englobaria tanto as regras legais quanto os princípios gerais. Certamente, neste sentido, a juridicidade traz melhor o que devem observar os agentes estatais, pois a totalidade das regras e princípios a nortear a atividade estatal de fato extravasa a estrita legalidade.

Aliás, a pertinência deste entendimento se conforma ao próprio significado de Estado de Direito, o qual tem a sua funcionabilidade adstrita a um dado modelo societário delineado no ordenamento jurídico vigente, sendo que as normas constitucionais oferecem as normas elementares deste modelo estatal, determinando a criação de suas instituições, estabelecendo as formas, as medidas e os procedimentos a terem validade dentro desta sistemática e deste Estado.

Assim, o agente público deve respeitar não somente a legalidade, mas, sobretudo, deve respeitar algo maior que ela: a juridicidade. Portanto, a preferência por este princípio se dá por razões evidentes, já que é ele um aglutinador de todos os princípios regentes da atividade estatal, trazendo a obrigatoriedade ao agente, de se orientar a partir não somente das regras, mas também, e principalmente, pelos princípios constitucionalmente prescritos. 
É certo que a lei, per si, não consegue prever toda e qualquer situação enfrentada pelo agente público no exercício de suas funções, o que faz com que exista, de fato, uma esfera dentro da qual há liberdade de ação. No entanto, esta liberdade não é irrestrita, devendo-se respeitar os critérios de conveniência e oportunidade; a esta esfera de liberdade denominamos discricionariedade administrativa.

No entanto, não há que se confundir a discricionariedade com a arbitrariedade. A discricionariedade dá permissão para se agir livremente, mas dentro dos limites da lei, observando e respeitando os princípios que regem a administração pública. A arbitrariedade, por sua vez, se faz presente quando são contrariados ou extrapolados os limites previstos pelo ordenamento jurídico vigente, determinado pelo princípio da juridicidade. De qualquer maneira, todos os atos praticados pelos agentes públicos devem ter uma razão de ser e de existir, o que pressupõe que devam ser publicamente motivados, aqui incluindo até mesmo os atos discricionários, que ficam, então, vinculados também à sua motivação.

Especialmente em relação à administração tributária, ou seja, à gestão dos recursos públicos, a juridicidade determina qual o direcionamento que se deverá dar à ação administrativa e quais os objetivos elementares que se pretende atingir com o empenho do recurso público - destacamos aqui novamente os objetivos fundamentais descritos no artigo $3^{\circ}$ da Constituição. A legalidade, por sua vez, é estabelecida com base no ordenamento jurídico e transparecida a partir das leis orçamentárias, as quais dão o exato direcionamento de como este recurso deverá ser empregado pelo administrador público.

Para isto estabeleceu-se a partir da Constituição de 1988 o ciclo orçamentário, o qual é formado a partir de três leis basilares e diretivas da ação estatal: o Plano Plurianual (PPA), a Lei de Diretrizes Orçamentárias (LDO) e a Lei Orçamentária Anual (LOA).

O PPA é construído periodicamente no primeiro ano do governo que assume a gestão pública. É esta lei que define as prioridades políticas para os próximos quatro anos; a LDO e a LOA são elaboradas anualmente, sendo que a primeira traça as diretrizes das Políticas a serem investidas, e a segunda define como será feito este investimento. Todas estão leis são constituídas em períodos contínuos e sucessivos, de forma a se complementarem, sendo que uma deve ser refletida na outra, ou seja, a base de todas é o 
PPA, a partir do qual se elabora a LDO e, com base nas duas anteriores, estabelece-se a LOA.

Estas leis orçamentárias têm iniciativa do Poder Executivo e são revisadas e aprovadas pelo Poder Legislativo, a partir do que se tornam o instrumento legítimo que embasa o empenho e a administração do recurso público. Devemos frisar que para a elaboração deste processo orçamentário deve-se respeitar e garantir a participação popular, pois se está se dando o direcionamento da aplicação do recurso público, ou seja, do total arrecadado a partir da contribuição de todos os cidadãos, não será legítimo, por não ser democrático, o processo que elaborar tais leis de uma forma fechada, distanciada dos maiores interessados: os cidadãos.

Assim, devem servir estas leis, amparadas e embasadas pelo ordenamento jurídico vigente, para emprestar grande parte da legalidade à administração tributária. Dizemos grande parte e não a totalidade, uma vez que estas leis são autorizativas de gastos e não necessariamente obrigatórias, visto que há margem para o contingenciamento dos recursos.

No entanto, é de fundamental importância frisar que por ser a ação dos agentes públicos direcionada inafastavelmente pelo princípio que ora estamos analisando, ou seja, pela legalidade, o desvirtuamento do recurso estabelecido nas leis orçamentárias somente será possível se for legitimamente justificado por uma necessidade legalmente prevista nestas e em outras normas, caso contrário o desvirtuamento do que está previsto na lei torna a ação ilegítima e o gasto manifestamente irregular.

Temos a suspeita tradição de realizar a alteração das leis orçamentárias por medida provisória (MP). Dizemos aqui suspeita, porque o seu uso desenfreado sugere uma ilegalidade, vez que esta medida foi prevista para ser utilizada em casos de relevância e urgência; claro que aqui não vamos decifrar estes conceitos, vamos somente nos ater à observação de que o seu uso deve se dar em último caso, demonstrado ser o seu uso imprescindível para atender urgentemente uma situação de considerável relevância.

Devemos lembrar que esta relevância não pode ser determinada pela vontade do agente público, mas está direcionada pela própria ordem constitucional. E por ser esta uma medida excepcional, não é lícito considerar tudo urgente e relevante, mas esta avaliação será feita com base na motivação dada para a edição de cada uma dessas MPs. 
Completamos a presente consideração afirmando que esta urgência e relevância deve estar refletida na vontade do povo, já que é esta a razão de ser, do poder representante.

Tanto que a MP, para ter força de lei, deverá ser submetida e aprovada pelo Congresso Nacional, dentro de um prazo de 45 dias, pois, do contrário, deve-se interromper todas as outras votações, até que a medida seja votada.

Apesar de o Congresso ter, no ano de 2001, aprovado alteração constitucional restringindo as áreas de abrangência das medidas provisórias e a dois, o número de vezes que pode ser reeditada, na prática ainda vemos este instrumento ser utilizado quantas vezes forem necessárias, sem a menor preocupação com a relevância ou urgência, comprometendo o seu uso.

Com o orçamento público, a situação não é diferente, pois as leis orçamentárias são devidamente aprovadas pelo Poder Legislativo, mas é comum vermos a alteração destas leis para retirar recurso de uma área e direcioná-lo para outra, sem que este ato seja feito tendo como base a urgência, a relevância e a preocupação de se respeitar a juridicidade, e, em especial, a legalidade trazida pelo PPA.

\subsection{Princípio da Impessoalidade}

O princípio da impessoalidade está intrinsecamente relacionado com o princípio da supremacia do interesse público, segundo o qual estes interesses não somente prevalecem sobre os interesses particulares, mas devem ser o guia motor da ação estatal, desde a elaboração legislativa até a prática efetiva de atos pela administração pública.

Melhor explicando, Odete Medauar leciona que o princípio da impessoalidade tem: "o intuito essencial de impedir que fatores pessoais, subjetivos, sejam os verdadeiros móveis e fins das atividades administrativas. Com o princípio da impessoalidade a Constituição visa obstacularizar atuações geradas por antipatias, simpatias, objetivos de vingança, represálias, nepotismo, favorecimentos diversos, muito comuns em licitações, concursos públicos, exercício do poder de polícia"10.

${ }^{10}$ MEDAUAR, Odete. Direito administrativo moderno. $11^{\mathrm{a}}$ ed. rev. e atual. São Paulo: Revista dos Tribunais, 2007, p. 124. 
É inconcebível a utilização dos "poderes” pelo titular do cargo ou função pública em beneficio próprio, pois assim estaria olvidando-se que a noção de serviço público é derivada diretamente do povo, estando qualquer agente lá somente para servir aos interesses primários do povo. Por tal razão jamais poderia confundir seus desejos e interesses particulares com a busca do interesse público. Diz-se usualmente que o administrador público não tem vontade, não é senhor de si, vez que ele deve desempenhar uma função a serviço da coletividade. Afinal de contas, não podemos perder de vista a determinação do parágrafo único do artigo $1^{\circ}$ da $\mathrm{CF}$, que traz de forma muito clara a questão da representatividade de qualquer poder, ou seja, diz que qualquer poder dentro deste país nasce do povo, e para atender aos seus interesses, é que se deve voltar.

Sabemos que, infelizmente, somos herdeiros de uma tradição bastante autoritária, o que faz com que alguns agentes simplesmente desconsiderem que devam agir direcionados pela superioridade do interesse público sobre os interesses individuais, ocasionando, muitas vezes, um exercício abusivo do poder que lhe foi concebido, causando transtornos, desmandos e corrupção. E foi justamente no sentido de alterar esta tradição que o legislador constituinte previu o presente princípio.

Considerando que o ato administrativo somente se realiza em prol do interesse público, podemos ir além e traduzir a própria representatividade dos atos praticados, que não são realizados em nome da pessoa que os praticou, mas em nome do ente estatal que a pessoa representa. Isto porque devemos considerar que o administrador é apenas um executor do ato, servindo de interlocutor a realizar a vontade estatal; ali naquele papel, a pessoa deixa de ser fulano ou sicrano, passando a ser o agente $\mathrm{X}$ ou $\mathrm{Y}$, que deverá atuar de acordo com as funções e atribuições juridicamente determinadas.

Neste sentido são os ensinamentos de José Afonso da Silva: “O princípio ou regra da impessoalidade da Administração Pública significa, em primeiro lugar, a neutralidade da atividade administrativa, que só se orienta no sentido da realização do interesse público. Significa também que os atos e provimentos administrativos são imputáveis não ao funcionário que os pratica, mas ao órgão ou entidade administrativa em nome do qual age o funcionário" ${ }^{21}$.

${ }^{21}$ SILVA, José Afonso da. Comentário contextual à Constituição. $3^{\text {a }}$ ed. São Paulo: Malheiros, 2007, p. 335336. 
Este princípio está, ainda, totalmente relacionado com o princípio anteriormente tratado, ou seja, da legalidade, uma vez que diz da direção e da finalidade de todo e qualquer ato administrativo, que deve ser guiado pelo seu fim juridicamente determinado, independentemente de expectativas e vontades subjetivas. Dentro de nosso Estado somente será válido o ato praticado para atingir os fins determinados pelo ordenamento jurídico, que também determina como deverá ser a sua forma de exteriorização dos atos, para serem considerados lícitos.

Uma forma de conexão deste princípio com o da moralidade, é notada a partir da reafirmação do direcionamento dos atos administrativos ao atendimento dos interesses da coletividade, que nos dizeres de Celso Antonio Bandeira de Mello assim sintetiza: "a Administração Pública está, por lei, adstrita ao cumprimento de certas finalidades, sendolhe obrigatório objetivá-las para colimar interesse de outrem: o da coletividade. É em nome do interesse público - o do corpo social - que tem de agir, fazendo-o na conformidade da 'intentio legis"'32.

Portanto, é justamente neste sentido que a Administração Tributária deve ser realizada, com vista a satisfazer os interesses coletivos a partir das diretrizes, objetivos, finalidades e formas desenhadas no ordenamento jurídico vigente.

\subsection{Princípio da Publicidade}

O princípio da publicidade vem respaldar a necessidade de transparência na Administração Pública. Desta forma, se as ações do Poder Público, como já dito, devem se pautar no escopo de satisfazer e atender aos interesses coletivos, a publicidade destes atos é um requisito fundamental para que o povo tenha o real e total conhecimento do que os administradores estão fazendo. Afinal de contas, e como já visto anteriormente, a teor do art. $1^{\circ}$, da CF, "todo o poder emana do povo, que o exerce por meio de representantes eleitos ou diretamente". Assim, para que a população, em seu conjunto, possa exercer este poder, a ela deve ser dado o integral conhecimento das ações estabelecidas e praticadas, tanto para poder avaliar as ações daqueles que as exercem em nome da coletividade, quanto para poder exercer de fato e qualificadamente este poder diretamente. Neste sentido

${ }^{12}$ BANDEIRA DE MELLO, Celso Antonio. Curso de Direito Administrativo. $14^{\mathrm{a}}$ ed., refundida, ampl. e atual. até a EC 35. São Paulo: Malheiros, 2002, p. 81. 
são os ensinamentos de Hely Lopes Meirelles ${ }^{13}$, que prossegue complementando e ampliando o entendimento do princípio da publicidade a todo e qualquer ato relacionado à Administração Pública, defendo a tese, da qual compartilhamos, de que a consagração da publicidade se dá para além da mera oficialidade divulgatória da ação.

Se os agentes públicos agirem sempre dentro dos padrões de conduta constitucional e legalmente - e moralmente - previstos, não há, realmente, nenhuma razão para que seus atos não sejam amplamente divulgados.

Aliás, devemos dizer que sempre quando se tratar de interesses e de patrimônios públicos não há razão para sigilo. Embora muitos agentes utilizem, de má-fé e em desacordo com a moralidade, esta argumentação para arbitrariamente escamotear dos cidadãos a realidade sobre a administração dos recursos públicos.

Devemos combater vigorosamente essa alegação de sigilo, principalmente, quando se tratar de interesses e de recursos públicos, pois, para se livrarem da obrigação de tornarem públicos seus atos e documentos relacionados, muitos argumentam, ardilosamente, com base no direito à intimidade e à privacidade, consagrados constitucionalmente. Isto ocorre comumente em relação ao sigilo bancário e fiscal, não somente dos agentes, mas também de alguns órgãos públicos, aos quais muitos agentes corruptos se agarram para tentar impedir que se esclareçam fatos ilícitos que têm envolvimento.

Vamos além, pois entendemos que, além de o princípio da publicidade atingir todo e qualquer ato realizado no âmbito do poder público, requer ainda mais em se tratando da publicidade na administração tributária.

Para melhor explicar tal afirmação, devemos recolocar que o recurso público, por ser formado a partir da contribuição, por diversas formas e meios, de todas as pessoas da sociedade, pressupõe que a sua administração e uso devam ocorrer a partir da mais legítima transparência, pois aquele que "paga a conta" requer que se preste contas minuciosas de sua aplicação.

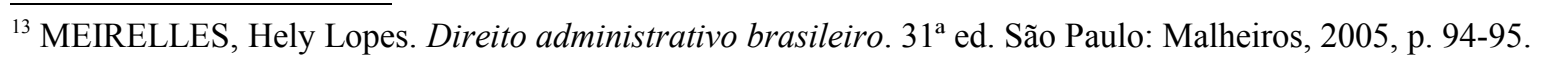


Trata-se da prestação de contas de uma outra obrigação constitucional, visando esta a dar transparência ao processo de execução orçamentária. Esta obrigatoriedade, estabelecida pelo artigo 165 , parágrafo $3^{\circ}$ da $\mathrm{CF}$, prevê a publicação de relatório resumido da execução orçamentária até 30 dias após o encerramento de cada bimestre. Ocorre que, em regra, esta prestação de contas é feita de forma altamente técnica, dentro dos padrões impostos pela contabilidade pública, não se tratando de um modelo compreensível para o cidadão comum.

Assim, defendemos que para atender ao presente princípio não basta trazer e dar publicidade de informações de forma genérica, devendo o administrador público - direto ou indireto - apresentar, especificamente, quando da prestação de contas financeiras, as informações detalhadas e especificadas da aplicação do recurso público, uma vez que, somente assim, estará se respeitando algo intrínseco à publicidade: a transparência. Isto porque defendemos a tese de que a publicação, quando da prestação de contas, de informações extremamente técnicas e genéricas não satisfazem a transparência na gestão do dinheiro público, vez que falta um elemento essencial à efetiva publicidade, ou seja, trazer sempre informações de forma clara e precisa para que todos aqueles do povo que, por ventura, queiram acessá-la, entendam a informação apresentada. Portanto, a mera publicização da informação respeita parcialmente o princípio da publicidade, que somente estará completo, com a democratização da forma e do conteúdo da informação publicada.

Devido à obrigatoriedade constitucional de prestar contas, isto é feito pelos órgãos administrativos e disponibilizado, até mesmo pela internet, a todos os cidadãos. Poderá até nos passar a impressão de ser o gasto público democraticamente controlado, mas basta um simples acesso para verificarmos que é feito de uma forma de difícil compreensão e altamente genérico, pois as rubricas são apresentadas ou por órgãos, ou por ação, por tipo de despesa ou até por favorecido, sendo relacionada sem maiores detalhes. Claro que o fato de todos podermos acessar as contas públicas, ainda que genericamente, já demonstra certo avanço social, pois assim podemos conhecer as prioridades governamentais, mas ainda encontra-se bem distante do ideal democrático, se considerarmos a distância de fato entre o Estado e a população.

Nesse diapasão, a transparência na Administração Pública está intimamente relacionada e somente é possível em governos com características democráticas, pois 
somente desta maneira viabiliza-se o controle da sociedade civil sobre o Estado, o que em certa medida visa a combater os desvios e abusos, contribuindo para o combate à corrupção - e, portanto, à imoralidade administrativa. Tanto que há aqueles que afirmam que é pelo grau de transparência de um Estado que se mede o seu grau de democratização. Esta transparência das ações governamentais é medida pelo grau de translucidez e de opacidade, pelo que poderemos observar, em maior ou menor medida, a realização da democracia.

Claro que este controle da sociedade civil somente é possível se o Estado criar condições que realmente aproximem o povo da Administração Pública, e não podemos ser ingênuos em acreditar que só ocorrerá com a abertura das contas públicas; acreditamos que é preciso algo mais, relacionado com o grau de consciência dos cidadãos quanto a seus direitos e com a capacidade de exercê-los devidamente.

Mas, em todo caso, está no acesso à informação uma precondição para a incorporação plena dos indivíduos e dos sujeitos coletivos ao processo decisório, contribuindo para que haja, organizada e qualificadamente, o monitoramento e a avaliação das ações governamentais.

Devemos, por fim lembrar que este princípio da publicidade está relacionado com a política de disseminação do acesso à informação sobre as ações governamentais como um todo, fazendo deste princípio algo que extrapole seus objetivos informativos, levando à promoção de um determinado governo, utilizando, para tal, estratégias de marketing, aviltando de todas as formas a ordem estabelecida, ferindo frontalmente todos os princípios do artigo 37 da Constituição.

O que se pretende com este princípio é possibilitar uma comunicação dialógica e interativa do Estado com a sociedade civil, justamente para romper esta concepção monológica da publicidade pois, quando o Estado oferece a informação, não está lidando com meros espectadores ouvintes, mas com cidadãos, sujeitos de direitos.

Inverter esta lógica é promover o desvio da finalidade do princípio, ora em comento, e tornar, assim, imoral o uso dos recursos públicos. 


\subsection{Princípio da Eficiência}

Trata-se do mais recente princípio, introduzido no art. 37 da CF, com o advento da Emenda Constitucional (EC) n. ${ }^{\circ}$ 19, de 4 de junho de 1998, consagrando a eficiência como princípio motivacional e norteador da atividade exercida pela Administração Pública, indicando que a atividade administrativa deve ser exercida com presteza, perfeição e rendimento funcional ${ }^{14}$.

Cabe ressaltar que a inclusão explícita deste princípio no rol do art. 37 vem no sentido de reforçar e consagrar as discussões que já eram feitas anteriormente, antes mesmo da $E C \mathrm{n}^{\mathrm{o}} 19$, pela doutrina e jurisprudência, reconhecendo a existência e a necessidade do respeito à eficiência quando atos praticados pelo ou em nome do Poder Público, entendendo-a como um implícito mandamento constitucional.

No sentido de relacionar a eficiência à economicidade, mesmo antes da EC n. ${ }^{\circ}$ 19, Márcia Filomena de Oliveira Mata, já afirmava que "o princípio da economicidade presente no art. 70 da $\mathrm{CF}$, em nosso entendimento reveste-se de conceito de eficiência caracterizado pela tentativa de com o mínimo de empregos de recursos e esforços, obter o máximo possível de resultados favoráveis" ${ }^{\prime 15}$.

É certo que o princípio da eficiência se impõe ao administrador. Entretanto, e como vimos, toda a sociedade é beneficiária desse mandamento, já que sem dúvidas, a efetiva arrecadação dos tributos de competência de um ente político e a sua correta aplicação é uma atitude que demonstra o emprego dos comandos determinados por essa principiologia.

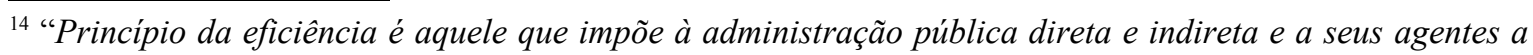
persecução do bem comum, por meio do exercício de suas competências de forma imparcial, neutra, transparente, participativa, eficaz, sem burocracia e sempre em busca da qualidade, primando pela adoção dos critérios legais e morais necessários para a melhor utilização possível dos recursos públicos, de maneira a se evitar desperdicios e garantir maior rentabilidade social." Cf. MORAES, Alexandre de. Direito constitucional administrativo. $3^{\mathrm{a}}$ ed. São Paulo: Atlas, 2006, p. 90.

${ }^{15}$ MATA, Márcia Filomena de Oliveira. Fiscalização da administração pública em face da economicidade. RT 710/233.
} 
Relacionando a inequívoca necessidade da boa administração com a eficiência da ação administrativa, Ricardo Lobo Torres observa que: "o aperfeiçoamento do controle é que pode derrotar a moral tributária cínica, que prega a sonegação e a desobediência civil a pretexto da ilegitimidade da despesa pública"16.

Deve-se enfatizar que não se pode tudo em busca da eficiência, pois é inaceitável que, embasado na busca pela eficiência na Administração, fira-se a legalidade. Assim, a Administração Pública deve atuar com eficiência, mas sempre dentro da legalidade - e, especialmente, da moralidade.

Assim, considerando que a eficiência tem uma umbilicada relação com a legalidade lato sensu, verificamos presente a ineficiência quando o agente ou o órgão público se afasta das atribuições que estão previstas no ordenamento jurídico. Ser eficiente é dever elementar da Administração Estatal, em seu mister de cumprir encargos, desempenhar funções, exercitar competências, fazer funcionar, enfim, um conjunto de deveres poderes que lhe comete a sociedade por meio da Constituição e das leis, em prol da satisfação das necessidades públicas ${ }^{17}$.

Especialmente em relação à Administração Tributária podemos empiricamente perceber que, em diversas ocasiões, situações e práticas administrativas, infeliz e nefastamente, este precioso princípio, que impõe uma administração eficiente dos recursos públicos, vem sendo largamente desrespeitado por diversos órgãos e agentes públicos, mas devemos lembrar que a partir deste desrespeito, por ferir um princípio constitucionalmente sacramentado, poderá, qualquer interessado, a partir dos meios cabíveis, acionar o Poder Judiciário para fazer valer e respeitar a eficiência quando do trato com a coisa pública.

\section{A MORALIDADE COMO PRINCÍPIO NORTEADOR DA ADMINISTRAÇÃO PÚBLICA}

\footnotetext{
${ }^{16} \mathrm{E}$ mais adiante o ilustre jurista complementa: "é pertinente invocar o princípio da eficiência no controle da capacidade dispenditiva do Estado, com vistas e aferir legitimidade da imposição tributária". (TORRES, Ricardo Lobo. Princípio da Eficiência em Matéria Tributária. Coordenador Ives Gandra da Silva Martins; conferencista inaugural José Carlos Moreira Alves. São Paulo: Editora Revista dos Tribunais, 2006, p. 77).

${ }^{17}$ PEREIRA JUNIOR., José Torres. Da reforma administrativa constitucional. Rio de Janeiro: Editora Renovar, 1999, p. 42.
} 
Inicialmente, preferimos apresentar cada um dos princípios norteadores da Administração Pública porque, como vimos, cada um se relaciona de alguma forma com a moralidade na administração tributária mas, por se tratar do princípio da moralidade administrativa o tema principal deste trabalho, preferimos apresentá-lo de forma separada dos demais. E, para ofertar maiores detalhes sobre este princípio, é que reservamos o presente capítulo.

\subsection{Antecedentes Históricos da Moralidade Administrativa}

O conceito de moralidade surgiu nos primórdios da humanidade. No decorrer do processo de formação social, muitas vezes é anterior ou se confunde com o próprio Direito.

Aristóteles refletia sobre a chamada excelência moral, considerando-a como expressão de virtude, devendo ser buscada nas ações humanas, por meio do discernimento. A partir de então, a reflexão sobre a moral ocupou um lugar de destaque nas obras dos filósofos mais importantes. Ficou assentada a relação entre a moral e a ação humana ${ }^{18}$.

O desenvolvimento do conceito de moralidade inicia-se com as relações estabelecidas no âmbito privado, dentro das quais se exigia um trato com bases éticas. Foi somente no século XX que a moralidade assumiu de fato posição relevante fora do campo do direito privado.

No entanto, não visualizamos historicamente que a constituição do Estado tenha se dado em paralelo com o respeito à moralidade na sua gestão e administração, visto que o seu nascedouro se deu ofertando poderes absolutos àquele que o administrava à época. Estes poderes absolutos permitiam ao monarca tudo que lhe conviesse, dentro de sua vontade subjetiva, o que abarcava certamente a interferência estatal em âmbito privado, fosse ou não direcionada por questões relacionadas e reconhecidas como morais.

A história e a evolução da humanidade condizem com as lutas sociais, e é também neste contexto de lutas, no período iluminista, travadas no sentido de colocar limites à

18 ARISTÓTELES. Ética a Nicômacos. Trad. de Mário da Gama Kuri. Brasília: Editora Universidade de Brasília, 1992. 
vontade do soberano, que se inicia a colocação de freios, com a elaboração de regras voltadas a controlar as ações dos agentes estatais, sendo que, a partir de então, o agente estatal passa a não mais poder tudo em nome do Estado. O controle passa a não mais ser estabelecido e voltado para controlar especialmente a ação privada e volta-se inversamente ao controle das ações do Estado contra a interferência arbitrária do Estado na vida dos cidadãos.

Para tal, fez-se necessário estabelecer a repartição dos poderes do Estado, visando ao controle recíproco entre cada um dos órgãos responsáveis pelas três funções especializadas do Poder Público.

Com esta reestruturação do modelo estatal, dá-se inicio a um processo, até os nossos dias em andamento, de repartição e democratização do poder ${ }^{19}$. Para isto passam a ser questionadas, e posteriormente positivadas, não somente o papel daqueles que se revestem do poder estatal, mas também as condutas e princípios que devem nortear as suas ações.

Devemos sempre ter em mente - e aqui neste trabalho faremos constantemente questão de enfatizar - que as funções e ações do Estado devem se fundar e se fundamentar nos interesses públicos. É pela perseguição deste postulado que se guia a evolução da sociedade - e a incessante luta dos movimentos sociais.

Neste contexto, a "grande arma" da modernidade utilizada para tentar refrear o arbítrio estatal é a lei. E foi a partir do aperfeiçoamento desta "arma" que vimos o "Estado Absoluto" evoluir e se transmudar para o "Estado de Direito". Isto fez com que a grande marca atualmente do Estado de Direito liberal se firmasse na vinculação dos atos da Administração Pública com o princípio da legalidade.

Assim, precisou-se instituir e estruturar uma forma de regular as ações dos agentes estatais, sendo que do ideal preconizado à época iluminista defendia-se que esta regulação deveria partir do povo, eis que surge a separação dos poderes e a especialização do Poder

\footnotetext{
${ }^{19}$ Afirmamos aqui que o processo de democratização do poder ainda é um processo em andamento porque defendemos a tese de que não basta a positivação de normas afirmando a democratização do poder para que ele se firme na sociedade, pois a Democracia é um conquista social que ainda precisa ser consolidada, especialmente no Brasil, e para o que muita luta e esforço social precisa ser empregado.
} 
Legislativo $^{20}$ na produção do direito, como forma de garantir o monopólio sobre a elaboração normativa à soberania popular, e fazer com que a vontade dos cidadãos prevalecesse sobre a vontade dos governantes.

Esta modificação do "governo do príncipe" para o "governo das leis", fundada na separação dos poderes, firmou-se de tal forma em nossa sociedade que hoje é ensinamento básico do Direito Administrativo o fato de a "Administração Pública somente poder a fazer algo desde que a lei assim o permitir". Assim, hoje a legalidade é princípio de orientação inafastável aos governantes.

Mas esta mesma referência histórica em relação à vinculação da atividade administrativa à legalidade, se por um lado apresenta um aspecto bastante positivo, no sentido de limitar as ações dos governantes, por outro lado foi responsável por desmembrar e separar como algo significativamente dissociável a política da moralidade, pelo que pagamos um preço alto até hoje e relação que tentamos com muito custo atualmente religar. A seguir passaremos a melhor explicar esta inicialmente estranha afirmação.

A consagração do princípio da legalidade, influenciada por um ambiente de afirmação e de estruturação da separação dos poderes do Estado, fez com que a doutrina enaltecesse e desenvolvesse a teoria da autonomia da política, e a autonomia da moral em relação ao direito, segundo o que a ética no exercício da administração pública não era tema afeito ao direito, a não ser que o poder legislativo excepcionalmente assim disciplinasse por meio de lei o agir administrativo. Isto significou a impossibilidade secular do controle da moralidade administrativa pelo Poder Judiciário.

Não podemos, ainda, nos olvidar de que o nascimento do Estado e a afirmação do ideário positivista vinham como relativa oposição à dominação de séculos exercida pelo poderio da Igreja Católica, portanto, a necessidade de se afirmar a separação entre Direito e Moral tinha um relativo fundamento no grande temor da interferência da moralidade cristã nos assuntos de Estado, que se pretendia se firmar como laico.

\footnotetext{
${ }^{20}$ Sua estruturação inicial se deu com base essencial na democracia representativa, ou seja, teorizava-se que o espaço deste Poder seria preenchido com representantes do "povo", os quais seriam os delegados legítimos a fazerem valer a vontade do "povo". Lembramos tratar-se aqui de um resgate teórico do surgimento da separação dos poderes, pois se verificarmos a partir da prática, temos ao longo da História, infelizmente, motivos de sobra para percebermos e questionarmos os reais interesses desses ditos "representantes do povo", e substancialmente os interesses que genuinamente perpassam esse Poder.
} 
Mas esta negação da moralidade - inicialmente aquela cristã -, na política, fez-se de forma tão radical que, a partir de um dado momento, passou-se a negar toda e qualquer forma de interferência da moral sobre o Estado, e com grande veemência passou-se a realizar - inicialmente de forma filosófica, e depois na prática - a separação entre a Moral e o Direito, o que acabou também por dissociar o exercício da política da moral e da ética, ditas comuns, já que aquele exercício tinha relação direta com o Direito, visto que emergia dele e por ele se direcionava.

É com o desenvolvimento da teoria kantiana, fazendo a defesa radical do positivismo jurídico, que a distinção e a autonomização entre o Direito e a Moral tornaramse filosófica e racionalmente defendidas. O professor Cláudio Ari Mello resume, com muita sabedoria, o pensamento de Immanuel Kant sobre a referida temática ${ }^{21}$ :

Seguindo a reflexão acerca da filosofia kantiana: "Para Kant, o direito se presta tão pouco quanto a moral a ser usado como ferramenta de uma idéia ou proposta eticamente superior. Não há fins que transcendessem a esfera jurídica, em relação aos quais o direito não passaria de meio e cujo alcance lhe daria sentido, legitimidade e consistência. Segundo Kant, não há valor acima do universo jurídico cujos préstimos possam enobrecer o direito" 42 .

Embora este teórico seja uma referência para muitos estudiosos, sendo, ainda neste século XXI, bastante estudado nos cursos de Direito, o questionamento à sua teoria com o passar do tempo passou a ser consequentemente feito - ainda que em quantidade muito menor do que é reproduzido como fonte. Aliás, passou-se a contestar o próprio positivismo jurídico, assim como a eficácia da legalidade no sentido de funcionar como base única ao controle judicial dos atos praticados pelos agentes públicos.

\footnotetext{
21 "Para Kant, a probidade jurídica é axiologicamente neutra, não havendo nenhum mérito no cumprimento dos deveres jurídicos. Os deveres de direito são sempre preferíveis às obrigações da virtude, porque os deveres jurídicos são exatos, e as obrigações morais são indeterminadas. Por isso Kant denominava os primeiros como deveres perfeitos, e os segundos como deveres imperfeitos. Para Kant não existe complementariedade entre direito e moral, o direito "não está a serviço da moralidade e tampouco se faz moralmente útil'”. (MELLO, Cláudio Ari. Fragmentos teóricos sobre a moralidade administrativa. In Revista de Direito Administrativo, n. ${ }^{\circ}$ 235, 2004, p. 102).

${ }^{42}$ Idem, ibidem, p. 103. Apud Immnuel Kant, A Metafísica dos Costumes. São Paulo: EDIPRO, 2003, p. 8588; v. José N. Heck. Direito subjetivo e dever jurídico interno em Kant. Porto Alegre: Veritas, vol. 48, n. ${ }^{\circ}$, $^{2}$ 2003, p.59-60.
} 
Paralelamente também foram feitos questionamentos sobre a necessidade de se agir eticamente no trato com a coisa pública, e em especial na administração dos recursos públicos, embora não tenhamos conhecimento de que o conceito da moral tenha se dado a partir desta esfera.

Sabemos que o conceito de moralidade é bastante antigo e que se desenvolveu consistentemente a partir da reflexão acerca das relações estabelecidas no âmbito privado, dentro das quais a ética há tempos é uma exigência social bastante evidente. A moralidade fora do campo do direito privado, por sua vez, é algo bastante recente, tornando-se relevante somente no século passado, o que ainda foi feito com bastante resistência, a exemplo do que ligeiramente expusemos em relação ao pensamento de Kant.

Foi especialmente no Direito Civil que pioneiramente se estabeleceram regras morais como norteadoras das relações, desfazendo-se com a onipotência do princípio da legalidade. Percebemos facilmente isto a partir da ideia de bons costumes. Se a realização de ideal de justiça é o objetivo do direito, começou-se a questionar o eventual empecilho advindo do engessamento normativo. A regra moral passou, assim, sorrateiramente a migrar para outros campos do Direito, atingindo, posteriormente, o Direito Público.

Mais especificamente, a moralidade administrativa nasce relacionada com a exigência, esperada do agente estatal, de que conduza a sua ação pautada exclusivamente por fins sociais, de caráter público, a partir do cumprimento e do respeito das regras estabelecidas pelo Direito posto. Nesse momento da história, o positivismo estava em auge no mundo jurídico, por isso a moralidade administrativa surgiu intrinsecamente relacionada com o direito positivo.

No âmbito judicial a moralidade administrativa foi primeiramente citada na França, consignada na jurisprudência do Conselho do Estado Francês, no início do século XX, quando se iniciaram as discussões acerca do desvio do poder ou da finalidade, momento em que se entendia a sua ocorrência a partir da prática administrativa, ainda que atuante no âmbito de sua competência, mas direcionada por fins ou por motivos diversos aos previstos em lei ou aqueles exigidos pelo interesse público. 
Assim, podemos afirmar que a moralidade administrativa nasceu associada com a ideia de desvio de poder do agente público, estando a imoralidade relacionada diretamente com a intenção deste agente em agir em desconformidade com as atribuições e competências devidamente estabelecidas para dado cargo, emprego ou função pública.

O conceito de moralidade administrativa fica mais bem delineado quando a aplicação da lei se revela moralmente questionável, o que foi expressamente referido, em 1914, por Maurice Hauriou, considerado um dos pioneiros a tratar da moralidade administrativa, referindo-se à moralidade no Direito Público como um princípio de observância inafastável à Administração Pública. Este renomado administrativista francês ressaltava, em seus julgados do Conselho de Estado Francês, que o conceito de moralidade administrativa compreendia o controle sobre os atos administrativos que vá mais longe do que a legalidade.

Todavia, foi na $11^{\mathrm{a}}$ edição de sua obra Précis de Droit Administratif et de Droit Public, que a temática foi melhor analisada, onde se lê: "Quanto à moralidade administrativa, sua existência provém de tudo que possuindo uma conduta pratica, forçosamente, a distinção do bem e do mal. Como a Administração tem uma conduta, ela pratica esta distinção ao mesmo tempo que aquela do justo e injusto, do lícito e do ilícito, do honorável e do desonerável, do conveniente e do inconveniente. A moralidade administrativa é frequetemente mais exigente que a legalidade. Veremos que a instituição do excesso de poder, graças à qual são anulados muitos atos da administração, é fundada tanto na noção de moralidade administrativa quanto na legalidade, de tal sorte que a Administração é ligada, em certa medida, pela moral jurídica, particularmente no que concerne ao desvio de poder"23 24 .

$\mathrm{Na}$ França, iniciado com Hauriou e seguido por outros, a moralidade administrativa se firmou e veio a ser conhecida como desvio de poder.

\footnotetext{
${ }^{23}$ HAURIOU, Maurice. Précis de Droit Administratif et de Droit Public. Onzième édition. Paris: Société Anonyme du Recueil Sirey, 1927, p. 25.

${ }^{24}$ No original: "Quant à la moralité administrative, son existence provient de ce que tout possédant une conduite pratique forcément la distinction du bien et du mal. Comme l'Administration a une conduite, elle pratique cette distinction en même temps que celle du just et de l'injuste, du licite et de l'illicite, de l'honorable et du déshonorant, du convenable et de l'inconvenant. La moralité administrative est souvent plus exigeante que la légalité. Nous verrons que l'institution de l'excés de pouvoir, grâce à laquelle sont annulés beaucoup d'actes de l'Administration, est fondée autant sur la notion de la moralité administrative que sur celle de la légalité, de telle sorte que l'Administration est liée dans une certaine mesure par la morale juridique, particulièrement en ce qui concerne le détournement de pouvoir".
} 
Desde então, até os nossos dias, o desenvolvimento acerca do que vem a ser conhecido como moralidade administrativa tem como base a teoria de Hauriou. Assim, temos um século de construção teórica sobre esta temática que se comunica e tangencia a produção feita no início do século passado por Maurice Hauriou, sendo certo de que muito pouco se conseguiu avançar, não sabemos dizer se pela excelência desta construção ou pela limitação das construções posteriores.

Ainda que seja esta a base das reflexões acerca da moralidade administrativa, uma coisa é certa: as possibilidades de seu enquadramento situacional são tão vastas quanto os significados que lhe foram ofertados. E é justamente esta imprecisão a responsável pela existência do temor histórico em se trazer a moralidade para o interior do Direito.

É fato que este temor afastou-a por muito tempo não somente das normas, mas também da prática administrativa, tanto que de todas as Constituições que de alguma forma nos influenciaram (Alemanha, Portugal, França, Espanha, Itália) nenhuma delas traz expressamente a palavra "moralidade administrativa", sendo somente em 1988 que uma Constituição trouxe o nome "moralidade administrativa" em seu bojo, sabidamente a da República Federativa do Brasil. Há também notícia de que a Constituição colombiana também faz referência à moralidade administrativa ${ }^{25}$.

\subsection{A Evolução do Conceito e do Instituto no Brasil}

No Brasil, apesar de a moralidade, enquanto princípio norteador de todas as ações praticadas por agentes que agem direta ou indiretamente em nome do Estado, ter sido consignada constitucionalmente em nosso ordenamento jurídico, somente em 1988, ela recebendo esta mesma ou outra denominação - já era, há muito, algo cobrado dos agentes públicos, inclusive judicialmente controlado e doutrinariamente tratado antes de 1988.

O Brasil, não muito diferentemente do que vemos pelo mundo, também tem em Maurice Hauriou as raízes do desenvolvimento teórico acerca da moralidade administrativa. Também se firmando no Brasil como diretamente relacionado com a teoria do desvio do poder ou da finalidade.

${ }^{25}$ GIACOMUZZI, José Guilherme. A moralidade administrativa - História de um conceito. In Revista de Direito Administrativo, n. ${ }^{\circ}$ 230, 2002, p. 291. 
O professor José Guilherme Giacomuzzi ${ }^{26}$ faz, com muita propriedade, uma consistente e dura crítica sobre o desenvolvimento teórico da moralidade administrativa no Brasil e da leitura feita nacionalmente acerca de Hauriou. Alerta-nos Giacomuzzi de que as ideias de Hauriou, assim como as de seus maiores discípulos Lacharrièrre e Henri Welter, no Brasil, foram desenvolvidas a partir de citação indireta, sendo que raríssimos juristas desenvolveram a teoria a partir da leitura direta da fonte francesa, o que, segundo ele, trouxe problemas de ordem teórica para a ideal compreensão acerca do tema.

Tais ideias chegaram, assim, a partir de um artigo intitulado "Moralidade Administrativa", escrito pelo advogado português Antônio José Brandão, originalmente publicado em 1947 no Boletim do Ministério da Justiça de Lisboa e reproduzido em 1951 no Brasil pela Revista de Direito Administrativo, volume 25. Foi por meio do renomado administrativista brasileiro, Hely Lopes Meirelles, que este artigo foi resgatado e recortado da Revista, e pelo qual determinado trecho ficou conhecido no Brasil. Foi assim que, já em 1964, Meirelles, na $1^{\mathrm{a}}$ edição de seu livro intitulado "Direito Administrativo Brasileiro" (p. 58-59), citava a moralidade administrativa. Reproduziu o seguinte trecho do artigo de Brandão:

"A moralidade administrativa, que nos propomos a estudar, não se confunde com a moralidade comum; ela é composta por regras de boa administração, ou seja: pelo conjunto de regras finais e disciplinares suscitadas, não só pela distinção entre o bem e o mal, mas também pela idéia geral de administração e pela idéia de função administrativa"27.

Assim, desenvolveu-se o conceito de moralidade administrativa no Brasil basicamente a partir do que está inserido neste pequeno trecho. Tanto que realmente é muito comum encontrarmos comentários sobre a moralidade administrativa, afirmando que esta não deve ser confundida com a moralidade comum, já que ela deve ser buscada no interior da administração; diz-se, ainda, que administrar com moralidade é sinônimo de bem administrar, cumprindo-se as atribuições juridicamente previstas para dada função no âmbito da Administração Pública. Assim, relacionou-se acertadamente a moralidade com a

\footnotetext{
${ }^{26}$ GIACOMUZZI, José Guilherme. A moralidade administrativa - História de um conceito. In Revista de Direito Administrativo, n. ${ }^{\circ} 230,2002$, p. 291 e seguintes.

${ }^{27}$ GIACOMUZZI, José Guilherme. A moralidade administrativa - História de um conceito. In Revista de Direito Administrativo, n. ${ }^{\circ}$ 230, 2002, p. 295. Apud Revista de Direito Administrativo $n .^{\circ}$ 25/459, Henri Welter, Le Contrôle Jurisdictionnel de la Moralité Administrative - Éstude de Doctrine et de Jurisprudence. Paris: Recueil Sirey, 1929, p. 77.
} 
ideia de se proceder com uma boa administração, e em respeito às funções administrativas descritas no ordenamento.

Embora aquele tenha sido o trecho recortado do referido artigo que nos foi apresentado, e a partir do qual se trabalhou o conceito no Brasil, o professor José Guilherme Giacomuzzi faz o resgate do texto original e traz a sua continuação, desconsiderada quando da sua citação, mas a qual diz ser elementar para o entendimento completo da moralidade administrativa. Portanto, o texto continua assim:

"De resto, o termo pouco importa, o todo é de se entender sobre os princípios"28.

Trazemos aqui esta observação, pois compartilhamos a crítica feita pelo sábio professor da nuclear importância deste trecho, ignorado pela doutrina brasileira, para o entendimento central do que vem a ser a moralidade administrativa.

Isto significa que o entendimento do que vem a ser a moralidade administrativa pressupõe um entendimento amplo sobre os princípios gerais que formam o nosso Estado Social e Democrático de Direito. O que há de principal é entender a nossa Constituição e, essencialmente, o "espírito de nossas regras constitucionais e infraconstitucionais". Somente a partir daí é que se poderá dizer o que é moral ou imoral nas intenções, motivações, meios, formas e ações dos agentes que cumprem função pública e manipulam e aplicam o nosso dinheiro.

Entendendo a globalidade da sistemática de nosso ordenamento jurídico é que poderemos avaliar se a gestão do recurso público está sendo moralmente realizada.

Aqui se pode verificar a dificuldade, e até a impossibilidade, de se esgotar o tema de nossa tese. Aliás, não é nossa intenção neste trabalho, o que pretendemos é basicamente promover uma reflexão sobre o elegido princípio e destacar a sua importância para o estabelecimento do Estado Social e Democrático de Direito em nosso país, arriscando uma intensionalidade voltada a contribuir na sua invocação prática para fortalecer a argumentação no exercício do controle social sobre as ações do Estado.

${ }^{28}$ Idem, Ibidem, p. 296. 
Isto porque agora, vista a moralidade sobre este parâmetro de respeito principiológico à nossa ordem, podemos dizer que nos causa um triste espanto apercebermos o seu desrespeito generalizado, pois não temos como considerar moralmente aceitáveis as prioridades políticas feitas ao longo de todos estes anos pelos diversos governos que sucederam a direção das esferas públicas neste país. Em uma simples análise sobre a forma como vem sendo gerenciado e empenhado o dinheiro do nosso povo, podemos inferir que está sendo administrado em desacordo total com a moral que socialmente esperamos.

Claro que há sérios problemas culturais que impedem a associação da política com a moral, cujas dificuldades em seu enfrentamento pressupõem ações por diversas frentes em conjunto, mas uma aqui queremos recortar, por atingir diretamente a nossa categoria: a tradição positivista do ensino do Direito no Brasil.

Por serem os juristas no Brasil formados e educados com bases nos paradigmas positivistas, o trato com a moralidade no Direito representa um terreno altamente nebuloso. Nós contamos com diversos doutrinadores intérpretes e raríssimos pensadores, poucos são aqueles que se arriscam a ultrapassar as demarcações positivistas, e por isto a colocação da moralidade no corpo de nossa Carta Magna pode ser considerada como um gigantesco desafio à nossa tradição jurídica.

Depois de mais de século afirmando a separação entre o Direito e a Moral, vem o nosso legislador constituinte consignar, no texto constitucional, o termo moralidade, obrigando-nos, ainda que inconscientemente, a desmistificar e desdizer tudo o que se afirmava com muita tranquilidade - e propriedade - até então. Pois é certo que a referida moralidade administrativa nos remete a uma zona que escapa do confortável campo da estrita legalidade e nos força a pisar neste terreno a fim de resgatar a moral, trazendo-a diretamente para o interior do Direito.

É inevitável chegar à argumentação sobre a presença ou ausência da moralidade sem analisar a amplitude não somente do ordenamento jurídico, mas também da ciência do Direito e de outras ciências sociais, como, por exemplo, a filosofia. Pois certamente não encontraremos uma norma que diz claramente, com os contornos e o enquadramento necessário à legalidade, que "praticar ou deixar de praticar um determinado ato é imoral", 
devemos fundamentar racionalmente a sua moralidade ou imoralidade. Eis ai um grande empecilho de nossa tradição à sua aplicação: a argumentação social racional.

O professor Cláudio Ari Mello diz sobre este estranhamento do Direito em se manusear internamente a moral que: "É absolutamente natural que inicialmente os intérpretes e aplicadores da Constituição tenham estabelecido uma relação de estranhamento com a idéia da moralidade administrativa. Positivar um princípio jurídico cuja operacionalidade dogmática remete o jurista para a esfera da moralidade é trazer de volta ao reino da pureza jurídica esse ser enjeitado e exilado que é a moral; é, também, reintroduzir nesse cenário asséptico a incerteza conceitual, a subjetividade hermenêutica, o emotivismo axiológico, é, enfim, renunciar em alguma medida aos paradigmas da certeza e da objetividade conquistados com a redução do direito à legalidade" ${ }^{29}$.

Há séculos, grandes filósofos disputam e se dedicam para trazer uma conceituação à moral, assim, nós, singelos juristas, não temos de fato formação suficiente para manipular este tema com desenvoltura.

Observamos na prática a grande relutância dos magistrados brasileiros em manusear, não somente conceitos não positivados, mas também de se embasar e dar efetividade aos princípios constitucionais. Na práxis judicial vemos com muita clareza o quanto as leis são preferíveis aos princípios. Desviando um pouco do foco administrativo e mirando para a prática do Judiciário na esfera criminal, isto salta aos olhos, pois de quase meio milhão de pessoas hoje privadas de sua liberdade neste país, quase a metade está presa provisoriamente (!). Não seria este um indício forte de desrespeito de um princípio elementar do Direito Penal Constitucional que determina a presunção de inocência a qualquer acusado?

Exemplificamos desta forma, com a finalidade de modelar a tendência judicial nacional de se sobreporem normas aos princípios, pois embora seja este um exemplo estranho ao Direito Administrativo, não podemos nos olvidar de que os operadores do Direito são formados - cada vez em maior número - a partir da mesma base positivista.

${ }^{29}$ MELLO, Cláudio Ari. Fragmentos teóricos sobre a moralidade administrativa. in Revista de Direito Administrativo, n. ${ }^{\circ}$ 235, 2004, p. 94. 
Por isso entendemos ser pertinente o argumento no sentido de evidenciar uma tendência brasileira legiscentrista.

Nesta tradição reside um grande empecilho de dar vida prática ao princípio da moralidade na política, especialmente no gerenciamento do recurso público.

Mas, percebemos - e isto não podemos deixar de dizer - que esta tradição vem se alterando, ainda que muito timidamente, e o grande salto positivo que queremos aqui destacar a vitaminar indiretamente esta evolução pôde ser verificada no último ano com a edição do Provimento n. ${ }^{\circ}$ 136/2.009 do Conselho Federal da Ordem dos advogados do

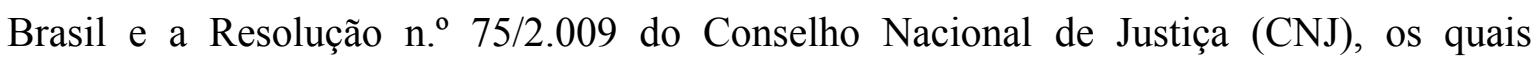
determinam que sejam exigidos em seus exames conhecimentos a respeito de matérias relacionadas essencialmente aos fundamentos do Direito, exigindo-se, para tanto, estudos nas áreas de Antropologia, Filosofia e Sociologia Geral e do Direito; Ética Geral e Jurídica; Economia, História do Direito, Psicologia Judiciária, Ciência Política e Direitos Humanos.

Desta feita, parece que nos encontramos em um importante momento de declínio da hegemonia positivista, estando evidente que os cursos de Direito terão que se adequar a esta nova realidade e oferecer uma visão holística a seus estudantes, fazendo com que cada vez mais compreendam e se pautem nos princípios. Este caminho que - esperamos - levará os cursos de Direito a se adequarem, acabará por emitir reflexos diretos na prática judicial, recheando a motivação das argumentações e decisões, influenciando positivamente para dar vida prática aos princípios jurídicos e para, um dia, aproximar de fato, a moral da política e, por consequência, da gestão de tudo o que é público.

Por nos encontrarmos no tópico relativo ao histórico da moralidade não podemos deixar de analisá-la a partir de sua introdução jurídica em nosso ordenamento, momento para o que nos dedicaremos a seguir.

No Brasil, a presença da moralidade administrativa em norma nacional foi uma realidade pela primeira vez em 11 de novembro de 1930, a partir da edição do Decreto n. ${ }^{\circ}$ 19.398, instituidor do Governo Provisório da República dos Estados Unidos do Brasil, o qual deu início ao período que conhecemos como a ditadura varguista. Aliás, algo que nos chamou bastante a atenção, pois a positivação primeira da moralidade administrativa no 
Brasil se deu em conjunto com a instituição de um governo altamente centralizador e autoritário $^{30}$.

Num primeiro olhar, parece-nos que realmente o subjetivismo intencional imperava no enquadramento do que era esta "moralidade administrativa". E, quando analisamos outros artigos deste mesmo decreto, esta intuição inicial se confirma ${ }^{31}$.

Fica claro, portanto, que este Governo Provisório tinha o poder soberano no interior da nação, neste cenário o que contravinha ou não à moralidade administrativa também ficava sob a análise subjetiva do Governo. Assim, certo era tudo aquilo que convinha politicamente àquele Governo.

Nesta toada, podemos afirmar que o surgimento da moralidade no Brasil ocorreu de uma forma absolutamente imoral.

Podemos concluir, então, que no Brasil a moralidade nasceu não para atender os interesses do povo, mas para atender os interesses políticos do governo à época e, fazendo uma ligação com a Administração Tributária, podemos dizer que este gerenciamento seguia pela mesma lógica de interesses. Embora hoje seja teoricamente inaceitável, na prática ainda encontramos perceptíveis resquícios, na Administração Pública, desta capciosa origem.

\footnotetext{
${ }^{30}$ Regia o art. $7^{\circ}$ do referido Decreto: "Continuam em inteiro vigor, na forma das leis aplicáveis, as obrigações e os direitos resultantes de contratas, de concessões ou outras outorgas, com a União, os Estados, os municípios, o Distrito Federal e o Território do Acre, salvo os que, submetidos a revisão, contravenham ao interesse público e a moralidade administrativa".

${ }^{31}$ Para que o leitor tenha a mesma percepção que a nossa, entendemos prudente reproduzir outros artigos do decreto que trazem a sua evidente intenção: "Art. $1^{\circ} \mathrm{O}$ Governo Provisório exercerá discricionariamente, em toda sua plenitude, as funções e atribuições, não só do Poder Executivo, como também do Poder Legislativo, até que, eleita a Assembléia Constituinte, estabeleça esta a reorganização constitucional do país;

Parágrafo único. Todas as nomeações e demissões de funcionários ou de quaisquer cargos públicos, quer sejam efetivos, interianos ou em comissão, competem exclusivamente ao Chefe do Governo Provisório.

Art. $2^{\circ}$ É confirmada, para todos os efeitos, a dissolução do Congresso Nacional, das atuais Assembléias Legislativas dos Estados (quaisquer que sejam as suas denominações), Câmaras ou assembléias municipais e quaisquer outros órgãos legislativos ou deliberativos, existentes nos Estados, nos municípios, no Distrito Federal ou Território do Acre, e dissolvidos os que ainda o não tenham sido de fato.

Art. $5^{\circ}$ Ficam suspensas as garantias constitucionais e excluída a apreciação judicial dos atos do atos do Governo Provisório ou dos interventores federais, praticados na conformidade da presente lei ou de suas modificações ulteriores".
} 
Embora possamos perceber esta nefasta origem nacional em relação à moralidade administrativa, um destaque positivo temos a obrigação de, aqui, fazer. Em 1965 houve finalmente uma acertabilidade legislativa indiscutível à garantia da moralidade na Administração Pública pois, ainda que isto tenha sido feito, não com o emprego desta nomenclatura, o seu conteúdo está devidamente consignado e normatizado na Lei de Ação Popular (LAP).

Portanto, nossa LAP, Lei de $n^{\circ} 4.717$, de 1965, traz em seu artigo $2^{\circ}$, parágrafo único, letra 'e', magistralmente uma conceituação sobre o desvio de finalidade, introduzindo em nosso ordenamento uma definição que apresenta a simplicidade e a pureza exigida dos textos legislativos e que acabou, segundo Giacomuzzi ${ }^{32}$, por eficientemente resumir uma produção secular do que se entendeu na França por desvio de poder. A LAP prescreve que: "o desvio de finalidade se verifica quando o agente pratica o ato visando a fim diverso daquele previsto, explícita ou implicitamente, na regra de competência”.

Assim ficou sintetizada a moralidade administrativa em nosso ordenamento no desvio de finalidade, verificado na prática do agente público que age de forma diversa daquela prevista na norma norteadora de sua competência. E foi assim que se seguiu o seu controle judicial a partir de então.

Em termos doutrinários, aponta-se o pioneirismo e a exatidão conceitual de Manoel de Oliveira Franco Sobrinho com a obra "O Controle da Moralidade Administrativa" 33 .

Embora a moralidade sempre tenha sido de certa forma uma exigência a acompanhar a ações estatais, é com a sua consagração explícita como princípio norteador da Administração Pública que se firma em nosso país uma moralidade constitucionalmente exigida no trato administrativo, e socialmente exigível por qualquer cidadão aos administradores públicos.

\subsection{Análise da Moralidade na Constituição Federal}

${ }^{32}$ GIACOMUZZI, José Guilherme. A moralidade administrativa - História de um conceito. In Revista de Direito Administrativo, n. ${ }^{\circ}$ 230, 2002, p. 296.

${ }^{33}$ FRANCO SOBRINHO, Manoel. O Controle da Moralidade Administrativa. São Paulo: Saraiva, 1974. 
Embora a construção jurisprudencial francesa tenha delineado os contornos do alcance da moralidade administrativa, seguida pela doutrina, tendo como paradigma até os nossos dias a obra de Hauriou, não há dúvidas de que sua expressa referência na Constituição da República de 1988 a consagra como princípio constitucional, criando um novo horizonte de possibilidades de concretização e efetivação, especialmente - devemos alertar a sociedade civil - na atividade tributária.

O princípio da moralidade, com o advento da atual Constituição Federal, foi alçado, pela vez primeira em nosso direito positivo, a princípio constitucional, nos termos do artigo 37, caput, o qual estabelece diretrizes à Administração Pública.

Também o artigo $5^{\circ}$, inciso LXXIII, da Constituição Federal, prevê a possibilidade de anulação de atos lesivos à moralidade administrativa, sendo legítimo para tal qualquer cidadão por intermédio de ação popular.

Segundo Luiz Vicente Cernicchiaro, "A "moralidade" administrativa, ao ser consagrada na Constituição da República, não obstante o nomen iuris, embora conservando as características próprias da Moral, foi "juridicizada". Como se repete, à semelhança de tudo o que Rei Midas tocasse, ouro se tornava, tudo que cai no Direito, jurídico se torna. A moralidade, assim, foi absorvida como princípio jurídico da Administração Pública" ${ }^{\$ 4}$.

A moralidade, então, passa a ser princípio informador de toda ação administrativa, sendo defeso ao administrador o agir dissociado dos conceitos comuns, ordinários, válidos atualmente e desde sempre, respeitadas as diferenças históricas, do que seja honesto, brioso, justo.

Devemos lembrar que não podemos entender a moralidade alheia aos demais princípios informadores da ação administrativa e, como já dissemos oportunamente, a legalidade é um princípio inafastável da Administração Pública, afirmar o oposto significaria desdizer tudo o que afirmamos anteriormente em tópico específico. Por tal

${ }^{34}$ CERNICCHIARO, Luiz Vicente. O Principio da Moralidade no Direito Tributário. Coordenador Ives Gandra da Silva Martins; conferencista inaugural José Carlos Moreira Alves. São Paulo: Editora Revista dos Tribunais, 1996, p. 39. 
razão devemos enfatizar que esta moralidade administrativa constitucionalmente determinada vem reforçar o nosso Estado Social e Democrático de Direito, significando, $a$ contrario sensu, tratar-se de um ato absolutamente imoral o agir administrativo em desacordo com o nosso ordenamento pátrio.

Não há de fato a necessidade de se buscar a moralidade administrativa fora do ordenamento jurídico, visto que à Administração Pública só e possível fazer o que a lei a autoriza. Assim, é dentro de uma análise sistêmica do ordenamento que se extrai a moralidade ou imoralidade da ação administrativa pois, do contrário, estaríamos dando brecha para subjetividades, visto que a moral comum não é de fato algo único ou até mesmo controlável.

Sobre o tema, é válida a lição de José Afonso da Silva de que: "a moralidade administrativa não é moralidade comum, mas moralidade jurídica. Essa consideração não significa necessariamente que o ato legal seja honesto. Significa que a moralidade administrativa consiste no conjunto de regras de conduta tiradas da disciplina interior da administração" ${ }^{\prime 35}$.

O não referir-se esta moralidade administrativa à moralidade comum significa que não deve ser influenciada por um moralismo publicamente despropositado e recheado de subjetivismo oriundo da paixão. É certo que, na maioria das vezes, no que diz respeito à administração da coisa pública, a dita moralidade comum, muitas vezes condiz com a intenção da moralidade administrativa, somente não prevalecendo em casos raros.

Mas, teoricamente, é importante frisar que não são equivalentes, pois esta moralidade comum levada às últimas consequências pode ser absolutamente injusta e desproporcional, e até mesmo irracional, dependendo do quanto ela é provocada ${ }^{36}$. E é no interior da administração que encontramos esta adequada medida moral e social.

Sintetizando as lições de Maurice Hauriou acerca da diferença entre a moralidade comum e a jurídico-administrativa, Hely Lopes Meirelles assim se manifesta: "Não se

\footnotetext{
${ }^{35}$ SILVA, José Afonso da. Curso de Direito Constitucional Positivo. $28^{\mathrm{a}}$ ed. São Paulo: Malheiros, 2006, p. 668.

${ }^{36}$ Há um fato bíblico de perfeito enquadramento que ilustra a possibilidade da injustiça coletiva, fomentada por uma moralidade comum, que foi quando, num momento de escolha dado ao povo palestino por Pilatos, livra-se o facínora Barrabás, entregando à tortura e ao extermínio Jesus Cristo em seu lugar.
} 
trata - diz Hauriou, o sistematizador de tal conceito - da moral comum, mas sim de uma moral jurídica, entendida como "o conjunto de regras de conduta tiradas da disciplina interior da Administração. O certo é que a moralidade do ato administrativo juntamente com a sua legalidade e finalidade, além de sua adequação aos demais princípios, constituem pressupostos de validade sem os quais toda atividade pública será ilegítima" ${ }^{\text {"37. }}$.

O acerto desta distinção se reforça no fato de nosso ordenamento jurídico formar suficientemente as ações que se esperam de dado agente na seara da Administração Pública, sendo, portanto, realmente desnecessário, embora não demasiado, buscar um conceito de moralidade administrativa fora do ordenamento vigente. Estamos certos de que o seu desvirtuamento, independentemente da motivação, já nos revela evidências de imoralidade; isto porque se espera do agente determinada ação, que será complementada com a ação do outro agente, e do outro e assim por diante, a fim de formar uma engrenagem que funcione como esperado pela sociedade.

A disfunção - ou o desvirtuamento - em uma dessas ações pode ser entendido, a nosso ver, como um nó na corrente estatal que desestabiliza as ações que lhe são consequentes, desestruturando um sistema juridicamente determinado e socialmente esperado. Por isto é, no mínimo, imoral desvirtuar-se do que se espera para aquela determinada função pública.

Também relacionando o princípio da moralidade com o comportamento esperado do agente que age em nome e em razão do poder estatal que lhe foi conferido por meio específico, nos ensina com grandiosa clareza Cármen Lúcia Antunes Rocha, a saber: "O acatamento do princípio da moralidade pública dá-se pela qualidade ética do comportamento virtuoso do agente que encarna, em determinada situação, o Estado Administrador, entendendo-se tal virtuosidade como a conduta conforme à natureza do cargo por ele desenvolvida, dos fins buscados e consentâneos com o Direito, e dos meios utilizados para o atingimento destes fins" ${ }^{\prime 38}$.

\footnotetext{
${ }^{37}$ MEIRELLES, Hely Lopes. Direito Administrativo Brasileiro. 33a ed. São Paulo: Malheiros, 2007, p. 89.

${ }^{38}$ ROCHA, Cármen Lúcia Antunes. Princípios constitucionais da administração pública. Belo Horizonte: Del Rey, 1994, p. 193.
} 
Podemos verificar, então, que as primeiras considerações de Hauriou acerca da moralidade administrativa, relacionando-a especialmente com o desvio de poder, ainda se mostram bastante atuais, apesar de sua construção datar de quase um século.

Apesar de que, devemos frisar, a legalidade por si só sabemos que é altamente insuficiente para prevenir o ato administrativa do agir imoral, pois pode - e não é incomum acontecer - que uma norma seja cumprida, mas a sua imoralidade está oculta na vontade subjetiva por qual está dirigida a ação, que é realizada no intuito manifesto de prejudicar alguém, ou como forma de auferir qualquer tipo de vantagem ao agente, ou a terceiro. Neste caso tem-se um comando formalmente legal, porém materialmente eivado do vício de imoralidade.

Assim, além de observar a legalidade que dá amparo de licitude ao ato, é preciso ater-se, principalmente, à finalidade para qual se destina a prática de determinado ato; é essencialmente daí que se extraem subsídios para avaliar a conformidade ou não com a moral. Portanto, há duas perguntas centrais a fazer: $o$ ato "x", que movimenta um recurso “y” está sendo praticado para atender qual finalidade? Para atingir a finalidade exposta, é proporcional e razoável o meio empregado?

Portanto, é crucial nos atentarmos à motivação dos atos administrativos, a partir da qual poderemos empiricamente avaliar se o seu meio e os recursos empregados são adequados para atingirem o fim a que teoricamente estão motivados. É por este caminho que chegaremos à avaliação da moral sobre o ato.

Como exemplo, podemos citar o Código de Ética Profissional do Servidor Público Civil do Poder Executivo Federal ${ }^{39}$.

Enfim, o princípio da moralidade requer que o agente administrativo pratique sim os atos de sua competência, mas não só; pretende que, além da observância dos preceitos legais, o interior de sua vontade esteja imbuído de um juízo de boa conduta. Em particular, o administrador público, no trato do erário, deve prezar por uma gestão fiscal responsável,

\footnotetext{
${ }^{39}$ Aprovado pelo Decreto n. ${ }^{0} 1.171$, de 22 de junho de 1994 - Anexo I, Capítulo I, Seção I, inciso III: “A moralidade da Administração Pública não se limita à distinção entre o bem e o mal, devendo ser acrescida da idéia de que o fim é sempre o bem comum. $O$ equilíbrio entre a legalidade e a finalidade, na conduta do servidor público, é que poderá consolidar a moralidade do ato administrativo".
} 
obedecendo, além dos preceitos legais, a um conjunto de ditames morais que imprimam a seu ato um caráter de honestidade e probidade.

Ressaltemos, ainda, que o princípio da moralidade está, de certa forma, relacionado não somente com o princípio da legalidade, mas com todos os demais princípios constantes do caput do art. 37 da Constituição Federal, pois sérios indícios de imoralidade são percebidos, ainda, quando o agente age por interesses alheios ao interesse público, desrespeitando a impessoalidade dos atos administrativos, ou quando os edita de forma sigilosa, afastando-se da transparência na sua realização; ou ainda quando eles são percebidos como ineficientes aos interesses da coletividade.

Portanto, podemos afirmar que há certa interpenetração dos referidos princípios constitucionais, não podendo, muitas vezes, fazer uma distinção clara de quando começa um e termina o outro, sendo que quase sempre a violação por um agente estatal a um dos princípios norteadores da Administração Pública ocorre simultaneamente à violação de outro ou de outros princípios.

Também relacionando o princípio da moralidade com os demais princípios constitucionais, não somente implícitos, mas também aqueles que estão implícitos no sistema constitucional, afirma Márcio Cammarosano: “A bem da verdade, a conjugação de princípios jurídicos como os da finalidade de interesse público, isonomia, motivação, razoabilidade, proporcionalidade, impessoalidade, publicidade, enfim, a conjugação de todos os princípios e subprincípios que Celso Antonio Bandeira de Mello aglutinou sob o título conteúdo do regime jurídico administrativo, somados aos princípios constitucionais da Administração Pública elencados no art. 37 da Lei Maior, já propiciaria controle dos mais amplos da Administração Pública, sem necessidade de invocação da moralidade"40.

Claro que o desrespeito especialmente a um dos princípios do art. 37, que não a moralidade, não significa uma automática violação a este princípio, pois a sua verificação requer um plus valorativo relacionado à intenção de dado agente e, somando, identifica-se a imoralidade administrativa.

40 CAMMAROSANO, Márcio. O princípio constitucional da moralidade e o exercício da função administrativa. Belo Horizonte: Editora Fórum, 2006, p. 73. 
Denominamos aqui um plus valorativo que se encontra normativamente amparado e reconhecido como a necessidade do agir administrativo embasado na lealdade, boa-fé, veracidade e honestidade. Neste sentido, Márcio Cammarosano resume o nosso entendimento ${ }^{41}$.

Assim, além de o agente público ter o dever de respeitar o nosso ordenamento, deverá fazê-lo com honestidade, boa-fé e probidade, pois somente está naquela função única e exclusivamente para a satisfação dos interesses coletivos e, ainda que trabalhar em prol do bem comum não tenha sido o incentivo inicial para a ocupação de um determinado cargo ou função pública, a sua permanência nele somente será legítima se for determinada e conduzida para o alcance dos interesses sociais. Admitir a sustentação de qualquer pessoa ou instituição, a ser paga com recurso público, para satisfazer mesquinhos interesses pessoais ou corporativos que sejam, utilizando-se do Estado para fazer jogos políticos, é algo indiscutivelmente imoral, motivo pelo qual devem ser estas práticas e estas pessoas lançadas para longe da máquina pública. Em resumo, entendemos ser isto que pretende com a arguição do princípio da moralidade administrativa, ou seja, almeja trazer a boa-fé e a honestidade para o interior do Estado, para que sejam os guias motores de suas ações, tornando simultâneas a política e a moral, para que se garanta, de fato e com qualidade, no interior desta nação, os diversos direitos sociais a todas as pessoas sem distinção.

É justamente por isto que, diferentemente do que entende Cammarosano sobre a desnecessidade da invocação da moralidade pela completude harmônica do sistema, já disposto a garanti-la, defendemos que precisamos usar e abusar desta terminologia, afirmando e denunciando genuinamente imorais as práticas administrativas tomadas em desvio do que determina o ordenamento jurídico pátrio.

\footnotetext{
41 "o princípio da moralidade administrativa não está referido direta e imediatamente à moral comum, individual ou social não institucionalizada, nem a este ou aquele ideal de justiça consubstanciado nas convicções pessoais de quem quer que seja, ou numa suposta justiça absoluta, universal. O princípio da moralidade está referido, isto sim, ao próprio Direito, remetendo-nos a valores que informam normas jurídicas. Estas, com seu 'inevitável conteúdo axiológico', seleciona valores que recolhe de outras normativas do comportamento humano, como a lealdade, boa-fé, veracidade, honestidade. Valores como esses, e porque juridicizados, devem ser prestigiados pelo Administrador Público. Este, ao interpretar as normas nas quais se refletem, visando sua aplicação, e ao avaliar situações de fato para detectar sua incidência, não pode ignorar o sentido que os conceitos que expressam valores têm sentido no seio da coletividade de que promanam, e em dado momento histórico, mas sempre atentos ao enfoque contextual do sistema normativo". (CAMMAROSANO, Márcio. O princípio constitucional da moralidade e o exercício da função administrativa. Belo Horizonte: Editora Fórum, 2006, p. 85).
} 
Ives Gandra da Silva Martins, ao enunciar os quatro princípios fundamentais da Administração, destaca a relevância e a especial importância da moralidade sobre os demais princípios, indo além do nosso entendimento ao dizer que o art. 37 da CF: "ofertou à moralidade relevo especial, visto que aquele governo que não for conformado pela moralidade, perde a autoridade para exigir dos administrados o cumprimento da lei”42.

Também entendendo pela supremacia da moralidade em relação aos demais princípios, Aristides Junqueira Alvarenga ressalta que: “dentre os princípios explicitados no art. 37, da CF, é inquestionável a supremacia do princípio da moralidade, que confere legitimidade à legalidade e impõe a observância da impessoalidade e da publicidade dos atos emanados da Administração Pública, como reflexos da moralidade"43.

Devemos destacar e adiantar a magnífica possibilidade trazida pelo art. $5^{\circ}$, LXXIII, da Constituição Federal, consistente na Ação Popular - que será analisada com maiores detalhes em tópico específico. Pela primeira vez na história deste país é garantido com todas as letras constitucionais a qualquer cidadão ser parte legítima a propor uma ação com vistas a anular um ato imoral praticado no interior da Administração Pública. Quem dos movimentos sociais e do povo tem a consciência sobre este enorme poder que lhe foi dado?

Assim, devemos prontamente deixar de criticar este princípio, por conta de sua imprecisão e generalidade, e começar a vivificá-lo e fazê-lo constantemente presente em nossas argumentações sempre que soubermos do desvio ou da má-administração de um recurso de caráter público. Talvez, um dia, possamos chegar ao fato de que o gerenciamento desonesto da máquina e do recurso estatal seja uma exceção.

Claro que não somos ingênuos a ponto de acharmos que somente com a arguição de um princípio constitucional o povo poderá se salvar da exploração histórica a que está exposto e do cultural uso do Estado para atender os interesses dos poucos detentores do poder. Diversos fatores devem ser gerenciados constante e simultaneamente para moralizar

\footnotetext{
${ }^{42}$ MARTINS, Ives Gandra. Estudos sobre o Imposto de Renda. São Paulo: Resenha Tributária, 1994, p. 1-3. ${ }^{43}$ ALVARENGA, Aristides Junqueira. O Princípio da Moralidade no Direito Tributário. Coordenador Ives Gandra da Silva Martins; conferencista inaugural José Carlos Moreira Alves. São Paulo: Editora Revista dos Tribunais, 1996, p. 46.
} 
o uso do dinheiro público, v. g., o aperfeiçoamento dos mecanismos de controle, o aumento da democratização do Estado, o que, por sua vez pressupõe uma educação voltada à constituição de cidadãos, conscientes e cientes da importância de seu papel no contexto político-social. Com estes exemplos, podemos ter uma noção clara sobre o quão difícil é este caminho que devemos trilhar. Mas acreditamos que a bandeira da moralidade fincada neste país poderá e deverá contribuir, conduzir e direcionar esta trilha social.

O princípio da moralidade administrativa, portanto, é princípio essencial. De extrema relevância, aquele que se destaca. Capaz de tornar a Administração confiável perante a sociedade, tornando o administrador público um ser diferenciado.

Em suma, o trato com a coisa pública, na visão daqueles que sempre prezaram os ideais de liberdade e democracia, deve exigir o máximo de responsabilidade e moralidade. O fato de manusear o produto do esforço coletivo, que é o dinheiro público, faz do administrador um sacerdote do poder popular, conferindo-lhe atribuições que, quando moralmente exercidas, alteram toda a história e programam um longo futuro.

\subsection{Alcance e Conteúdo da Moralidade na Administração Tributária}

O Estado deve sempre buscar o bem-estar da sociedade, impondo aos governantes e aos servidores públicos a obrigação de serem pessoas de categoria moral superior, que visem apenas a servir o povo e não o contrário.

O constituinte de 1988, ao eleger o princípio da moralidade como um dos mais relevantes princípios da Administração Pública, a ponto de dar a todo cidadão o direito ao remédio processual superior (a Ação Popular), e ao Ministério Público e organizações nãogovernamentais, instrumento de igual força para combater desvios a tal princípio (Ação Civil Pública), buscou o legislador conferir aos brasileiros o exercício do controle social sobre a ética dos detentores do poder.

Vale lembrar que não temos a pretensão de esgotar aqui o tema, mesmo porque, se a ideia central da moralidade, é de se entender sobre os princípios, podemos dizer que cada um originaria um trabalho à parte. A pretensão é disparar reflexões práticas sobre a 
importância da observância da moralidade quando da administração de um recurso de caráter público.

Este trabalho traz reflexões acerca de uma questão central para o desenvolvimento social: como vem sendo utilizado o dinheiro público? Ora, se vivemos em uma sociedade cujo modo de produção ocorre em bases capitalistas, não há como se desenvolver socialmente de outra forma, dentro deste sistema, que não seja com o emprego de capital em áreas centrais e estratégicas.

Pretende-se, aqui, fomentar a reflexão sobre o gerenciamento do dinheiro público. A sua aplicação vem sendo feita essencialmente para cumprir os Princípios Fundamentais da República Federativa do Brasil, conforme ordena o art. $3^{\circ}$, de nossa Carta Política? O recurso adquirido graças ao suor do povo brasileiro vem sendo aplicado nestas últimas duas décadas no sentido de garantir o desenvolvimento nacional? De construir uma sociedade livre, justa e solidária? De erradicar a pobreza e a marginalização? Vem sendo empregado para reduzir as desigualdades sociais e regionais? Está, de fato, promovendo o bem de todos, sem distinção e sem preconceitos de origem, raça, sexo, cor, idade e quaisquer formas de discriminação?

Se a resposta a estas perguntas for negativa e, infelizmente, sabemos que é, o que devemos fazer? Podemos agir ou simplesmente temos que aceitar esta má administração pública generalizada?

É neste sentido, e a partir do fomento destas reflexões, que pretendemos contribuir socialmente com este trabalho e é a partir deste momento que queremos analisar o alcance da moralidade.

Quem presta concurso, é eleito, exerce cargo de confiança ou exerce indiretamente a função pública, ou seja, todo aquele que recebe ou administra, de qualquer forma, recurso público, deve saber que o objetivo final de sua ação é servir ao povo, portanto, sua probidade deverá ser absoluta, pois seu exemplo é fundamental para que as instituições sejam estáveis e sirvam de fato para cumprir os objetivos que fundamentam a existência do cargo que ocupa. 
Por esta razão, houve por bem o constituinte tornar o princípio da moralidade o mais relevante do concerto daqueles que perfilam a Administração Pública, não havendo setor desta, direta ou indireta, que não deva ser por ele embasado.

Todavia, a prática imoral em relação à administração do recurso público é cotidianamente realizada. Dispensar sem razoabilidade ou ludibriar o processo licitatório; superfaturar obras públicas; repassar verbas sem criterização racional às Organizações Não-Governamentais; gastar excessivamente com viagens e estadias; financiar alimentação desnecessária e provida só a alguns agentes públicos unicamente por ocuparem cargo de posição politicamente "privilegiada"; utilizar a publicidade pública para realizar marketing político; sucatear generalizadamente as políticas sociais são exemplos da amplitude com que a imoralidade vem sendo habitualmente verificada na administração do recurso público, afrontando de forma certeira o mandamento constitucional.

O desvio da finalidade do recurso público é sem dúvidas um dos grandes desafios de nossa época, o qual precisa ser enfrentado sem tardar. Não há atalhos nem respostas simples e imediatas. Estamos conscientes de que a má administração e o desvirtuamento da coisa pública, em maior ou menor grau, representa uma ameaça constante para as instituições democráticas, para a proteção do meio ambiente, enfim, para a realização dos direitos humanos em sua globalidade, além do que não somente impede o desenvolvimento social, cultural e econômico das pessoas residentes neste país, mas é responsável pelo aumento da pobreza e do abismo da desigualdade social. Se a irracionalidade na governança não for obstada e continuar sendo determinada pela cobiça e por motivos individuais, em vez de pelas reais necessidades do povo, seremos obrigados a reconhecer a derrocada deste sistema e decretar a ilegitimidade de todas as ações estatais, por demasia e evidente incongruência com o que foi legitimamente consagrado pelo povo brasileiro, quando do acordo popular firmado em nossa Constituição Federal.

Portanto, quando se diz que o gasto público deve ser feito em respeito ao princípio da moralidade, quer dizer que as ações do Estado têm que se adequar a esta nova realidade constitucional e servir unicamente para satisfazer os seus mandamentos; se não estiver sendo feito assim, o seu uso está sendo imoral, podendo e devendo ser anulado. 
Não vamos aqui ser céticos e desconsiderar os avanços sociais, desconsiderando nossa própria história que traz marcas perfeitas de que estamos lidando com um problema antigo. Não temos como esquecer que o ouro e a riqueza expropriada do território e do povo brasileiro financiaram a Revolução na Inglaterra. A corrupção eleitoral é algo que nos acompanha desde a instituição da Primeira República. Já na década de 20 houve uma conhecida luta promovida pela Aliança Liberal em favor da moralidade administrativa, mas foi vencida pela Revolução na década de 30. Pelo preço da construção de Brasília pagamos o preço até hoje. Quem sabe para onde foi todo o tesouro recolhido, em 1964, pela campanha "Ouro para o bem do Brasil" promovida pelo governo federal, que comoveu milhares e milhares de pessoas a ponto de levá-las a doar desde suas alianças de matrimônio até vultosas quantias em dinheiro? Quem não conhece o lema que levou Jânio Quadros à presidência na década de 60, que fez da vassoura da moral o seu principal e maior símbolo?

Ao trazermos estes fatos, não pretendemos naturalizar este problema e afirmar que o "mau caratismo" é algo inerente à política brasileira, que os fatos sempre foram assim e precisaremos conviver eternamente com este problema. Sabemos da existência de uma corrente teórica que traz estas situações e este resgate histórico não com o propósito de fomentar a indignação e a revolta social, mas de promover o conformismo e a acomodação em relação a esta ultrajante situação. Nós não compactuamos deste propósito, muito pelo contrário, queremos justamente desmistificar esta naturalização da imoralidade política e reafirmar que podemos e devemos alterar o rumo da história, sob pena de levarmos a humanidade para o enorme buraco da destruição social. Mesmo porque este ceticismo pessimista levado às últimas consequências poderá nos trazer um imenso retrocesso social, pois sabemos que o cenário político perfeito para amoldar as ditaduras e a supressão dos direitos vem justamente do discurso da necessidade de trazer moralidade à política, ou não foi este o discurso forjado quando do golpe militar em 1964? Lembramos, assim, que recentemente este extremismo discursivo pela necessidade da promoção da moralidade política foi responsável por um retrocesso brusco em nosso processo evolutivo, criando uma mancha de 20 anos de desserviço do Estado brasileiro à sua população, equívoco pelo qual estamos até hoje pagando o preço. Esta lembrança é fundamentalmente importante para não reproduzirmos o mesmo erro social. 
Assim, não queremos e não podemos desconsiderar os avanços sociais, e atualmente temos uma série de exemplos para afirmar que temos consideráveis e visíveis ganhos sociais com o sistema democrático que pretendemos sedimentar e consagrar.

Um forte e evidente exemplo refere-se ao amplo conhecimento e maior publicidade que deveria haver sobre as ações do governo, pois, ainda que permeada por um excessivo tecnicismo e por uma generalidade da qual contundentemente discordamos, é fato que as contas públicas e os gastos governamentais estão alocados no sistema web, disponível pela internet e acessível a qualquer cidadão, em qualquer parte do mundo. Embora extremamente técnico e genérico, podemos dali extrair as prioridades políticas feitas pelo governo e saber no que está sendo empregado e para o que está sendo utilizado o nosso dinheiro. Eis um considerável avanço no que diz respeito à possibilidade do exercício do controle social sobre os gastos públicos.

Reforçando este exemplo de ganhos conseguidos graças à estruturação do processo democrático, citamos o "Portal da Transparência", disponível no endereço www.portaltransparencia.gov.br, o qual, por iniciativa da Controladoria-Geral da União (CGU), foi criado com o objetivo de aumentar a transparência da gestão pública e de contribuir no combate à corrupção no Brasil. Foi lançado, no final de 2004, para ser um canal e possibilitar a qualquer cidadão o acompanhamento da execução financeira dos programas de governo, em âmbito federal. Lá estão disponíveis informações sobre os recursos públicos federais transferidos pelo Governo Federal a estados, municípios e Distrito Federal - para a realização descentralizada das ações do governo - e diretamente ao cidadão, bem como dados sobre os gastos realizados pelo próprio Governo Federal em compras ou contratação de obras e serviços, por exemplo. A gestão das Páginas de Transparência Pública é regulamentada pelo Decreto n. ${ }^{\circ}$ 5.482, de 30 de junho de 2005 e pela Portaria Interministerial n. ${ }^{\circ}$ 140, de 16 de março de 2006, que determinam a divulgação de dados e informações pelos órgãos e entidades da Administração Pública Federal na internet.

Embora tenhamos sérias críticas em relação à forma com que as informações estão dispostas, pelo seu ainda alto grau de tecnicismo e de generalidade das rubricas apresentadas, fato é que isto era algo absolutamente impensável de acontecer antes de 2004. Devemos frisar, também, que a possibilidade de promover o acompanhamento da 
execução orçamentária também foi se alastrando aos demais entes federativos, e hoje podem ser acompanhadas pela internet, em maior ou menor grau, as contas de praticamente todos estados e municípios brasileiros.

Faremos aqui um destaque em nossa crítica apresentada, por entender que esta se relaciona diretamente com o princípio da moralidade. Se verificarmos estas prestações de contas governamentais, veremos que sua forma não vem sendo moralmente realizada, pois a fundo não sabemos quanto foi e para o que foi usado cada real.

Para nos aproximarmos da inadequação deste formato pegamos um exemplo prático de nossa casa. Vamos supor que em dia de feira seja disponibilizada e entregue à funcionária a quantia de cinquenta reais para ela comprar o que está faltando em casa, e ela, com uma lista de itens na mão, vai à feira. Pois bem, após feitas as compras, vamos querer saber se os itens da lista foram comprados, se não foram, o porquê, e se outros foram comprados a mais, vamos querer saber o motivo, e ela terá que explicar se aquele item era realmente necessário. Este é o formato que entendemos adequado de elaborar e executar o orçamento público, um formato que certamente contribuirá para prevenir o desvio de verbas públicas e gastos desnecessários. É claro que há um longo caminho até este formato ideal, mas é por ele que devemos nos guiar.

A prestação de contas deve ser feita de modo que qualquer cidadão entenda o que está ali disposto, item por item, facilitando o exercício do controle dos gastos públicos pela população. Não é adequado que se precise contratar um técnico para decifrar os códigos orçamentários e, enquanto ainda não alcançarmos esse modelo ideal, a forma continuará sendo democraticamente falha.

Também entendemos não ser adequado que esta prestação de contas seja feita com base em dados unicamente quantitativos, pois dizer que se investiu " $X$ " milhões na educação é o mesmo que nada dizer. Portanto, é necessário expressar o gasto público em termos qualitativos, eis o grande desafio para o próximo período.

Portanto, além da obrigação de informar o quanto foi gasto, deve-se justificar a qualidade deste gasto, o que se fez, e para que se fez, além da necessidade de apresentar a efetividade da ação realizada. Aliás, a avaliação dos resultados alcançados é essencial para 
analisar a coerência do gasto público, para saber se foi proporcional, razoável e eficiente o seu emprego e, ainda, se for aplicado de forma falha ou desconecta com o nosso ordenamento e desatrelada à real necessidade do povo, o responsável deve justificar o porquê do desvio. É isto que devemos buscar alcançar, pois quanto mais conectado o gasto com a sua realidade e efetividade, mais se estará contribuindo para o estabelecimento de um Estado justo, racional e moral.

Esta radicalização democrática sobre as contas públicas visa, acima de tudo, a romper com a prática patrimonialista e privatista dos ciclos de geração, preservação e transmissão da informação no intra e inter Estado. Por isto mesmo não pode ser realizada de forma a prestar contas do Estado para si mesmo. A política deve ter como premissa e sustentação o reconhecimento do direito e o acesso à informação governamental e à consolidação do Estado de Direito, baseando-se na concepção de cidadania ativa. Afinal de contas, a função pública está a serviço do público. E quanto maiores os instrumentos criados para possibilitar a incorporação da sociedade civil nos processos de formulação, implementação, monitoramento e avaliação de políticas, maiores as chances de realizarmos o bem comum.

Frisamos que a moralidade do gasto público não está somente na prestação de contas pelo governo, pois assim parece que de um lado está o Estado trabalhando, recolhendo e gastando o recurso público, e de outro lado está a sociedade civil, pronta para receber a informação de como o dinheiro foi gasto. Um Estado verdadeiramente Democrático não fomenta seres apáticos, meros receptores, mas contribui para a formação de agentes capazes de exercerem ativamente a sua cidadania.

Assim, a participação da sociedade civil deve ocorrer desde a elaboração das leis orçamentárias, consensuando e determinando as prioridades governamentais. Para isto pressupõe-se o fomento da descentralização governamental, pois quanto mais próxima a população estiver desta possibilidade de participar da construção das diretrizes, objetivos e metas da administração pública, mais se estará adequando o Estado ao cumprimento de seus objetivos, isto porque determina o $\S 1^{\circ}$, do artigo 165 , da Constituição, que estas prioridades devem ser estabelecidas de forma regionalizada. Realmente esta é uma forma acertada para buscar, ou seja, promover a consulta popular em todas as localidades, das mais centrais às mais periféricas, pois não há melhores conhecedores da realidade local que os próprios moradores, são eles os melhores e mais experts "técnicos sociais" a dizer o que 
precisa ser melhorado e o que está faltando em seu bairro. Eis um outro ideal a que devemos democraticamente nos adequar, pois é inconcebível que os gastos públicos sejam feitos de forma vertical de cima para baixo; uma democracia pede a horizontalidade das decisões, o que inclui o estabelecimento das prioridades orçamentárias.

Aos técnicos governistas cabe o apoio e o amparo técnico no planejamento para satisfazer a vontade popular. Para tanto deve-se viabilizar o diagnóstico da situação que se pretende atacar, com o diagnóstico realiza-se a análise do quadro de problemas a serem enfrentados, definem-se focos de atuação, objetivos, metas, resultados e impactos esperados e, por fim, desenham-se as formas de monitoramento. É esta a forma correta de funcionamento de um Estado Democrático, pois o gasto desarrazoado e despropositado ou, ainda que tenha um propósito não firmado de forma clara, certamente não contribuirá para verdadeiramente enfrentar os problemas sociais, e continuaremos a combater somente as consequências e não as causas das quais decorrem os problemas.

Em relação à democratização da informação conforme frisamos, ainda bem, não foi feita apenas pela internet, pois sabemos e temos consciência de que a inclusão digital no Brasil ainda é algo que não atinge todas as pessoas. Parte das informações sobre as ações da administração pública chegam diariamente até o interior de nossos lares também pelo sistema televisivo de comunicação, este sim já absolutamente democratizado e acessível por todos.

No entanto, esta ampliação do conhecimento e o alastramento da publicidade sobre as ações praticadas no interior do Estado e da Administração Pública pode, por vezes, ser mal interpretada e promover a desconfortável sensação de que "nunca houve tanta corrupção", como comumente ouvimos dizer. Devemos constantemente desmistificar este tipo de fala e reconhecer que se, hoje, muitas ações imorais em relação à administração de nosso dinheiro sejam amplamente conhecidas e divulgadas, isto também é fruto de uma luta social de anos que contribuiu na promoção da abertura das ações governamentais, o que também consideramos um ganho merecedor de destaque.

Por outro lado, também vemos muitos atores da classe política se aproveitarem da situação e utilizarem o discurso da moralidade e da inaceitabilidade da corrupção, mas apenas enquanto ardilosa retórica para acusarem pessoalmente seu adversário político 
partidário e para terem visibilidade, não apresentando propostas concretas para promoverem o real enfrentamento do problema.

Vemos cotidianamente - e em ano eleitoral observamos com maior intensidade - as acusações pessoais e partidárias, como se o desvio da finalidade da coisa pública fosse um problema individual, o que desvia o foco de que grande parte do problema é ocasionado por sérias falhas estruturais do sistema. Não podemos nos permitir entrar neste jogo pequeno de interesses e reproduzir este teatro politiqueiro.

Devemos realmente enfrentar este histórico problema do desvio do dinheiro e da finalidade de tudo o que é público, mas de forma racional, séria e realista, levados por interesses, mas suprapartidários e de propósitos coletivos, pois se a desmoralização na política é favorável a somente alguns "privilegiados", certamente a sua moralização beneficiará todo o povo brasileiro. Neste sentido a moralidade nos foi dada como um grande trunfo a ser juridicamente usada para contribuir com o redirecionamento dos rumos de nossa história que não pode mais esperar.

\section{PRINCÍPIOS VINCULADOS À MORALIDADE ADMINISTRATIVA}

Por diversas vezes já dissemos que não há como analisar a moralidade administrativa de forma estanque e isolada, sendo que a relação existente entre os princípios é algo indissociável, por isto preferimos tratar de cada um dos princípios dispostos no art. 37, da CF, relacionando-os diretamente com a moralidade. No entanto, para entender a moralidade administrativa, é preciso compreender os princípios determinados por nosso ordenamento jurídico de uma forma ampla, e há outros também bastante importantes à compreensão da moralidade que não estão explicitados no art. 37, e é para o entendimento destes que reservamos o presente capítulo.

No entanto, é importante frisar que não nos propomos a conceituar cada um dos princípios, mesmo porque para cada um deles é compatível uma tese em especial; o que pretendemos é trazer uma ligeira concepção, relacionando-a com a moralidade na 
administração do recurso público, de forma a contribuir para com o entendimento da importância destes princípios e como são aliados estratégicos para exercício do controle social.

A existência de um Estado Democrático de Direito se fundamenta no cumprimento da vontade de um determinado povo, esboçada por meio de seu ordenamento jurídico em vigor. Este Estado tem que se direcionar por um único caminho: o dos objetivos fundamentais delineados constitucionalmente (artigos $1^{\circ}, 3^{\circ}, 4^{\circ}, 5^{\circ}, 170$ e 193 da Constituição). Assim, é para alcançar estes objetivos que se destina a aplicação do dinheiro público, qualquer outro direcionamento é ilegítimo. É certo que para tanto não há um caminho único, podendo haver diversas formas de se chegar lá, um mais longo, outro mais curto, uma encruzilhada, um labirinto, ou até uma trilha fora do mapa social, e justamente para direcionar o melhor caminho para alcançar tais objetivos é que se direcionam os princípios constitucionais. Seriam os princípios, as diretrizes para a diminuição da desigualdade social e melhoria da qualidade de vida de todos, indistintamente, enfim, para a construção de uma sociedade dignamente mais justa.

O Direito não pode mais continuar sendo um instrumento de conservação do status $q u o$, espera-se em nossa época que seja um importante instrumento a promover a transformação social, e os princípios, neste cenário, são genuínas máquinas fomentadoras da realização correta deste arcabouço normativo.

Mas, para tanto, precisamos desmistificar urgentemente a parte doutrinária e jurisprudencial que nega vivificar os princípios constitucionais, fundamentada em sua suposta subjetividade. Queremos firmar com este trabalho que há total concretude em cada um dos princípios que estrategicamente trazemos, e que devemos a eles dar vida prática e aplicabilidade em casos reais e concretos sempre que se tratar da administração e do gerenciamento de todo e qualquer recurso com caráter público.

É para rechear e contribuir com o controle social no manejo da receita tributária, que nos direcionamos, afirmando que a imoralidade na administração da coisa pública é algo inaceitável e que devemos torná-la intolerável. Para tanto, temos uma série de subsídios, de ordem constitucional, para na prática refrear o abuso e fazer prevalecer o que entendemos por moral. 
A partir da juridicização da moralidade, o seu controle pode ser judicialmente realizado, e são os princípios constitucionais que aqui trazemos, que vão direcionar e enriquecer a argumentação jurídica quando de sua arguição. Eis o sentido de trazer os princípios a seguir que, em certa medida, relacionam-se diretamente com a moralidade administrativa.

\subsection{Princípio da Boa-fé}

Trata-se a boa-fé de um dos institutos mais antigos, sendo legítima herdeira do Direito Romano, no qual condizia com expectativas de condutas objetivas, previsíveis e adequadas socialmente àquela época. Em Roma a boa-fé não correspondia a algo adormecido, pois era absolutamente presente e operante nas relações cotidianas entre os cidadãos e entre os Estados. Naqueles tempos a palavra dada era lei, não porque as normas assim o diziam, mas porque correspondiam à veracidade e à honestidade dos valores éticos e morais da época. A dinâmica romana pautava-se no respeito dos vínculos e promessas; a honestidade e a retidão moral, segundo os padrões de comportamento esperado do homem médio romano, prevaleciam sobre a conveniência. Boa-fé, portanto, significava a expectativa de comportamento conforme a norma, fosse ela ética, moral ou jurídica.

Por esta breve exposição sobre a origem deste instituto podemos perceber o quanto sofreu alterações no decorrer da História. Se em Roma a boa-fé era a base e a regra das relações sociais, transmudamo-nos hoje para um tempo em que este modelo de interação social, infelizmente, está rareando. Não porque nos tornamos socialmente desonestos e não confiáveis, mas porque a dinâmica social de nossa época nos impôs um formato de dinâmica pautado no sucesso individual a todo custo. Eis o cerne de nossos problemas para lidar naturalmente com o instituto da boa-fé.

Vivemos em tempos em que pensar no coletivo, o que equivale a respeitar os outros, não somente nós mesmos, está cada vez mais se esvaindo das relações, cada vez mais pautadas em querer obter privilégios, seja na escola, no trabalho, no trânsito, em "furar fila", em não devolver o troco dado incorretamente, na minha rua, na busca por um emprego, no gerenciamento dos negócios privados e, também, públicos. A nossa cultura 
social do "deu, levou" e do "defender somente os meus" acabou por dar uma outra conotação à boa-fé.

Portanto, não devemos esperar que a boa-fé sobrevenha naturalmente do indivíduo em particular, que nasça da palavra como ocorria em Roma, a não ser que sejamos tão ingênuos a ponto de considerar que todas as pessoas são boas, pensam de forma coletiva, não querem ser beneficiadas às custas do outro ou dos outros, e o que leva intimamente uma pessoa a se tornar um funcionário público não é nem de longe o salário e as "vantagens", mas sim o poder e querer fazer o bem para todas as pessoas.

Difícil hoje concebermos tamanha ingenuidade e, neste contexto, a boa-fé não é mais algo passivo que devemos esperar dos cidadãos, especialmente daqueles que estão no gerenciamento dos negócios estatais; hoje, a boa-fé passou a ser aquela normatizada juridicamente, trata-se de algo imperativo, ordenada e exigível, que deve ser constantemente cobrada dos agentes públicos.

Ter boa-fé na Administração Pública e no gerenciamento dos recursos públicos equivale a agir em consonância com o que determina o ordenamento jurídico. A honestidade e a retidão não serão averiguadas "na cabeça" do indivíduo, mas na sua ação conforme o que determinam as normas sociais juridicizadas.

O princípio da boa-fé apresenta uma profunda vinculação com fatores éticos e morais, traduzindo dados da realidade fática das relações humanas valoradas pelo Direito.

Isto porque entendemos ser este ordenamento o reflexo da "consciência da sociedade", e ali está firmado o desejo da coletividade em relação os agentes públicos, diretos ou indiretos, é o ordenamento jurídico que traz os imperativos éticos que sacramentam o que é socialmente esperado da utilização, com boa-fé, do dinheiro público.

É neste sentido, de preservação dos interesses da coletividade, que se insere, dentre outras tantas normas jurídicas, o princípio da boa-fé, o qual ocupa papel de notória relevância na sistemática de controle das ações administrativas. 
Assim, traz a boa-fé não somente um aspecto diretivo e imperativo da ação estatal, mas também um aspecto que delimita e refreia o arbítrio funcional dos agentes públicos, pois atropela-se a boa-fé e configura-se evidente má-fé o dispêndio do dinheiro público e o agir administrativo desprendido tanto dos fins quanto dos meios legitimamente prescritos pelo ordenamento.

Por tais razões é que traz este instituto uma relação extremamente íntima com a moralidade administrativa a ponto de se confundir com ela ao exigir que a administração pública atue com veracidade, honestidade e lealdade. Assim, embora a Constituição não preveja expressamente a boa-fé, ela é exigível objetivamente como decorrência do princípio da moralidade previsto no art. $37^{44}$.

\subsection{Princípio da Vedação do Comportamento Contraditório}

Em nosso ordenamento jurídico, a proibição ao comportamento contraditório tem por finalidade a manutenção da coerência em todas as relações jurídicas.

Para uma parte da doutrina, a vedação ao comportamento contraditório nada mais é que um desdobramento do princípio da boa-fé, que funciona em colaboração para o controle do exercício do direito.

Para que se configure o comportamento contraditório, é necessário que o ato não seja originalmente vinculante e sobre sua possibilidade de contradição o legislador não tenha expressamente se manifestado. Pois, se assim o for, não haverá a necessidade de arguição específica do presente princípio, bastando alegar a ilegalidade do ato para que a sua anulação seja considerada. Este princípio reforça, portanto, o reconhecimento de que a estrita legalidade não é suficiente para solucionar todos os conflitos e atender a todas as necessidades sociais.

Realmente, como veremos, de fato o princípio da vedação do comportamento contraditório possui uma relação direta com a boa-fé objetiva, sendo também, por vezes,

\footnotetext{
${ }^{44}$ RUBINSTEIN, Flávio. Boa-fé objetiva no Direito Financeiro e Tributário. Série Doutrina Tributária, vol. III. São Paulo: Quartier Latin, 2010, p. 79.
} 
tratado pela doutrina como o princípio da tutela da confiança legítima ou, ainda, como nemo potest venire contra factum proprium.

Este instituto tem o objetivo de tutelar a coerência dos atos praticados no interior da Administração Pública, uma vez que, após praticado um determinado ato por um agente, desde que este gere expectativas concretas aos cidadãos, todos os demais atos que sobrevierem a este primeiro têm que ser realizados no sentido de respeitar e atender estas expectativas geradas; atraiçoá-las evidencia uma má-fé, inadmissível por este princípio e, por tal razão, passível de anulação. Neste sentido, este princípio determinaria a vinculabilidade de certos comportamentos, ainda que estes não estejam legalmente previstos.

A proibição do comportamento contraditório visa, portanto, a estabelecer e a manter a coerência das ações realizadas, ao mesmo tempo em que funciona como um instituto protetor da confiança despertada na contraparte - quando se tratar de um contrato - ou em terceiros - em se tratando de ato genérico. Assim, vem para advogar em prol da coerência, da confiança depositada e das expectativas geradas.

Este princípio assume o papel de instituto controlador dos comportamentos dos indivíduos no interior da máquina estatal, sendo, por conseguinte, instrumento de realização da confiança e da boa-fé.

Em breves linhas trata-se da proibição de o agente praticar uma conduta ou um ato contrário a um primeiro ato já praticado, desde que aquele viole as expectativas legítimas despertadas nos cidadãos, podendo este ato, inclusive, causar-lhe prejuízo de ordem material ou moral. Portanto, trata-se da proibição de uma conduta que, embora inicial e aparentemente lícita, torna-se abusiva por conta das circunstâncias concretas e dos atos anteriormente praticados.

Neste sentido, o colendo Superior Tribunal de Justiça, admitindo princípio em voga em nosso ordenamento e aplicando-o a um caso concreto, já decidira que em: "havendo real contradição entre dois comportamentos, significando o segundo quebra injustificada da confiança gerada pela prática do primeiro, em prejuízo da contraparte, não é admissível dar eficácia à conduta anterior". (Resp n. ${ }^{\circ}$ 9.553-9 - SP - Min. Ruy Rosado de Aguiar). 
Em considerando que as pessoas, quando no desempenho de sua função no interior da administração pública, vestem-se da institucionalidade estatal, não estando, portanto, ali enquanto pessoas, mas enquanto agentes que desempenham um determinado papel e representam um determinado órgão estatal, podemos afirmar que a vedação do comportamento contraditório estaria relacionada não somente com a fidelidade de um ato praticado, mas também com a fidelidade da palavra dada por um dado agente público.

O vincular uma pessoa, neste caso, às suas atitudes faz, a nosso ver, justo sentido, uma vez que reforça a teoria do cumprimento de papéis, dos agentes públicos, algo fundamental para a concretização das expectativas sociais trazidas e depositadas em nossa Constituição.

Percebemos, assim, a importância em vedar a ocorrência de comportamentos contraditórios, especialmente para contribuir e proteger a confiança, a legítima expectativa, a lealdade, a probidade, a lisura e a honestidade nas relações entre o Estado e a sociedade civil.

\subsection{Princípio da Probidade Administrativa}

Corolário do princípio da moralidade administrativa, a probidade administrativa restou consignada em nível constitucional no $\S 4^{\circ}$, do artigo 37, da $\mathrm{CF}^{45}$.

A doutrina assegura a correlação entre o princípio constitucional da moralidade e o dever de probidade do agir administrativo. Vejamos as razões de Fábio Medina Osório: “a improbidade decorre da quara do dever de probidade administrativa, que descende, diretamente, do princípio da moralidade administrativa, traduzindo dois deveres fundamentais aos agentes públicos: honestidade e eficiência funcional mínima"46.

\footnotetext{
45 “Art. 37, § 4 , da CF: Os atos de improbidade administrativa importarão a suspensão dos direitos políticos, a perda da função pública, a indisponibilidade dos bens e o ressarcimento ao erário, na forma e gradação previstas em lei, sem prejuízo da ação penal cabível".

${ }^{46}$ OSÓRIO, Fabio Medina. Improbidade administrativa. Observações sobre a Lei 8.429/92. $2^{\text {a }}$ ed. Porto Alegre: Editora Síntese, 1998, p. 61-62 (itálico original).
} 
Cabe lembrar, com efeito, que respeitado setor doutrinário sustenta que a probidade administrativa estaria necessariamente ligada à ideia de moralidade administrativa, o que torna necessário o exame mais detido do dever de probidade constitucionalmente imposto aos agentes públicos.

A improbidade administrativa tem profunda conexão com o princípio da moralidade administrativa, sendo que tal premissa não pode ser objeto de dúvidas fundamentadas.

Sobre o assunto, Wallace Paiva Martins Júnior também assevera: “O princípio da moralidade administrativa impele o agente público a atuar de forma mais completa do que simplesmente agir conforme a lei, na medida em que insere na gestão da coisa pública uma exigência de habilitação moral, e sua desobediência conduz à nulidade do ato" ${ }^{\text {" }}$.

Trata-se, enfim, da probidade administrativa, sem dúvida, de um desdobramento direto da moralidade, mas se destacando especialmente por estar relacionada a situações em que esta imoralidade é qualificada pela vitimização do Estado.

É certo que para uma imoralidade com qualificação tão prejudicial socialmente não poderia deixar de serem firmadas sanções legais quando de sua incidência. E assim o foi, sendo que a seguir traremos brevemente as sanções civis e político-administrativas, dispostas em Lei especial e, em outro capítulo comentaremos as sanções penais.

Em decorrência do mandamento constitucional inscrito no $\S 4^{\circ}$, do artigo 37, CF, houve a elaboração e edição da Lei n. ${ }^{\circ}$ 8.429/92, comumente conhecida como a Lei da Improbidade Administrativa.

Com efeito, trata-se de norma dirigida à punição de condutas incompatíveis com a probidade e a moralidade administrativas, atuando por meio de sanções de natureza civil e político-administrativa aplicadas em processo judicial, é dizer, reprimem-se ilícitos político-administrativos sob a imposição de sanções extrapenais.

${ }^{47}$ MARTINS JUNIOR, Wallace Paiva. Probidade Administrativa. $4^{\mathrm{a}}$ ed. São Paulo: Editora Saraiva, 2009, p. 45. 
Por ato de improbidade administrativa pode-se compreender todo aquele que, praticado por agente público, configure violação às normas da moral e à lei, caracterizando-se pela falta de honestidade e de retidão de conduta em face da Administração Pública, seja direta ou indireta, e demais entidades a que a lei visa a proteger. Como se pode concluir, é bastante ampla a gama de condutas capazes de ferir a probidade administrativa, de sorte a fazer pertinente a lição da Professora Maria Sylvia Zanella Di Pietro: “a legalidade estrita não se confunde com a moralidade e a honestidade, porque diz respeito ao cumprimento da lei; a legalidade em sentido amplo (o Direito) abrange a moralidade, a probidade e todos os demais princípios e valores consagrados pelo ordenamento jurídico; como princípios, os da moralidade e probidade se confundem; como infração, a improbidade é mais ampla do que a imoralidade, porque a lesão ao princípio da moralidade constitui uma das hipóteses de atos de improbidade definidas em lei”48.

A lei em comento, ao regulamentar o referido dispositivo constitucional, classificou os sujeitos ativos e passivos, as sanções cabíveis, o procedimento administrativo e judicial para a apuração das infrações disciplinadas e, é claro, os atos de improbidade. É claro que não vamos nos ater à caracterização de cada um desses itens, vamos somente destacar alguns tópicos que consideramos importantes, já deixando recomendado que, para maior aprofundamento se dirijam olhares à própria lei. Cumpre salientar que três são as modalidades de atos de improbidade administrativa prevista na Lei n. ${ }^{o}$ 8.429/92. São elas: atos que importam enriquecimento ilícito (art. $9^{\circ}$ ); atos que importam dano ao Erário (art. $10^{\circ}$ ); atos que atentam contra os princípios da Administração Pública (art. 11). De fato, cada uma dessas previsões tem a si ligada uma série exemplificativa de condutas pelas quais as referidas violações podem se manifestar, compondo, destarte, um rol bastante heterogêneo e não taxativo.

Para Maria Sylvia, "o mesmo ato pode enquadrar-se em uma, duas ou nas três hipóteses de improbidade previstas na lei. Por exemplo, a omissão ou retardamento na prática de ato que deveria ser praticado de ofício, prevista no inciso II, do artigo 11, pode causar prejuízo para o erário, incidindo no artigo 10, e o enriquecimento ilícito no exercício do cargo, incidindo também na regra do artigo $9^{\circ}{ }^{\circ 9}$.

\footnotetext{
${ }^{48}$ DI PIETRO, Maria Sylvia. Direito Administrativo. $20^{\text {a }}$ ed. São Paulo: Atlas, 2007, p. 745-746.

${ }^{49}$ Idem, ibidem, p. 761.
} 
Sujeito ativo da improbidade é o agente público e/ou particular beneficiado pelo ato de improbidade administrativa. Na esteira do que previsto no artigo $1^{\mathrm{o}}$, da lei em comento, a tutela se constrói em favor das pessoas jurídicas de direito público - União, Estados, Distrito Federal, Municípios e Autarquias; das fundações públicas; das empresas públicas, sociedades de economia mista, empresas incorporadas ao patrimônio público ou entidades para cuja criação ou custeio o erário haja concorrido ou concorra com mais de $50 \%$ (cinquenta por cento) do patrimônio ou da receita anual; das entidades que recebem subvenção, benefícios ou incentivo, físcal ou creditício, de órgão ou empresa pública.

Como já registrado, a prática de atos de improbidade sujeita o agente à imposição de sanções civis ou político-administrativas. Estas, conforme a dicção do artigo 12, da lei em destaque, são as seguintes: ressarcimento do dano; perda da função pública; suspensão dos direitos políticos, por tempo que varia conforme a modalidade da violação perpetrada; multa civil, cujo valor segue, outrossim, o tipo de ato de improbidade; proibição de contratar com o Poder Público ou receber benefícios ou incentivos fiscais ou creditícios, direta ou indiretamente, ainda que por intermédio de pessoa jurídica da qual seja sócio majoritário, por prazo definido de acordo com o ato praticado; além da perda dos bens ou valores acrescidos ilicitamente ao patrimônio, quando tal ocorrer.

Vale acrescentar que há divergência doutrinária quanto à aplicação das sanções previstas na Lei de Improbidade em face da qualidade dos agentes políticos, pois que alguns deles, como o Presidente da República, os Senadores e os Deputados Federais e Estaduais, defende-se não estarem sujeitos a algumas das sanções ali dispostas, como, por exemplo, à pena de perda da função pública. $\mathrm{O}$ entendimento majoritário preconiza a aplicação da lei também em relação a esses agentes, atendendo-se, entretanto, às peculiaridades do cargo na definição das sanções a serem aplicadas ${ }^{50}$.

Enfim, pela legislação podemos ver que a improbidade é interminantemente repudiada pelo nosso ordenamento, prevendo sanções que a nosso ver condizem com a seriedade do tema, pois é certo que uma sanção de cunho unicamente penal não satisfará as necessidades sociais. Assim, acertou nosso legislador na elaboração e edição da norma em testilha, pois não queremos somente ver a prisão dos infratores, mas queremos principal e essencialmente que a situação de violência contra o Estado, o que inclui toda sociedade,

\footnotetext{
${ }^{50}$ Nesse sentido, ver M. S. Z. Di Pietro. Direito Administrativo. $20^{\text {a }}$ ed. São Paulo: Atlas, 2007, p. 755-758.
} 
seja restaurada e que os bens e valores desonestamente surrupiados sejam-nos devolvidos com juros e correção monetária.

\subsection{Princípio da Proporcionalidade}

Este princípio não está expresso na Constituição, mas a exigência de sua orientação se observa a partir da interpretação sistemática do Direito. Por isto mesmo, o seu entendimento e análise também são indissociáveis à interpretação do Direito.

O princípio da proporcionalidade é corolário de uma ordem jurídica na qual a Constituição Federal assume o ápice do sistema normativo. Essa supremacia constitucional é o ponto de partida para a compreensão do princípio da proporcionalidade.

Fazer justiça nada mais é que fazer escolhas, o que na prática nem sempre é simples, e a missão deste princípio é, justamente, contribuir para a realização deste sopesamento.

Sem dúvida este princípio serve para obstar o abuso estatal e proteger os interesses

e os direitos sociais. É no estabelecimento de freios e na indicação dos fins das ações estatais que a proporcionalidade presta os seus maiores contributos.

O princípio da proporcionalidade surge como princípio regulador e harmonizador dos conflitos, na aplicação e na proteção dos direitos do homem e da dignidade humana, funciona como controle dos atos estatais, com a inclusão e manutenção desses atos dentro do limite da lei e adequado a seus fins.

Sabemos que a Constituição Federal indica os direitos e garantias fundamentais que devem ser garantidos a todos os cidadãos, no entanto, não prescreve a forma, não diz o meio de realizá-los, mas é claro que não pode ser feito ao belprazer do Estado, o qual encontrará limites e estará necessariamente vinculado à proporcionalidade.

A proporcionalidade vem para garantir, quando da administração do recurso público, que a sua administração seja pautada por um sério juízo de adequação, necessidade e conformidade, a fim de que sua aplicação vise sempre a cumprir os objetivos fundamentais constitucionalmente determinados. 
Assim, o princípio não é em nada algo teórico e acadêmico, trata-se de algo com reflexos exclusivamente práticos, pois é na prática e diante do caso concreto que ele vai agir direcionando e avaliando as ponderações feitas, esboçadas nas motivações reais apresentadas para justificar o gasto público, estas sempre analisadas em paralelo com a finalidade que se diz querer atingir.

Pois bem, a proporcionalidade a ser avaliada sobre o gasto público pressupõe a presença simultânea de três aspectos: adequação, necessidade e proporcionalidade em sentido estrito.

A adequação determina que se faça uma verificação com vistas à finalidade justificante do gasto, a partir do que se fará uma apreciação racional e real sobre a aptidão dos meios utilizados para tal. Ou seja, para atingir o objetivo que se pretende, utiliza-se um meio racional e realmente adequado? Com a execução de tais meios se alcançará necessariamente o fim objetivado? Se a reposta for sim haverá adequação, caso contrário, poder-se-á pleitear a anulação dos atos inadequadamente realizados.

A necessidade, por sua vez, pede que seja realizado o gasto com o menor custo possível, ou seja, gastar-se-á somente o necessário para se atingir o fim pretendido. É neste aspecto da proporcionalidade que reside a impropriedade do dispêndio do dinheiro público, do gasto excessivo, o que inclui também o superfaturamento de que tanto ouvimos falar.

A proporcionalidade em sentido estrito traz consigo uma ideia de conformidade, e pressupõe um juízo de valor direcionado a avaliação dos meios existentes e possíveis à realização do que concretamente se pretende em determinado caso. Além do que se volta também a avaliar a própria finalidade do gasto, se está em conformidade com os objetivos efetivamente positivados pelo ordenamento jurídico. Sabemos que dentre os direitos e garantias há aqueles que são fundamentais à dignidade humana e aqueles que vêm estabelecidos de forma secundária, e este aspecto da proporcionalidade também se direciona pela ponderação analítica desta hierarquia garantista.

Esta análise pode parecer difícil, mas a prática, com base em determinado caso concreto, acaba por facilitar a avaliação, ofertando-nos subsídios de sobra para inferir 
sobre a proporcionalidade do gasto, e a partir de então identificar a sua moralidade ou imoralidade.

Seu verdadeiro sentido é que a proporcionalidade deverá pautar a intensidade dos atos praticados, levando-se em conta, a finalidade que se propõe alcançar. Não visa ao emprego apenas da letra da lei, mas de sua proporção aos casos concretos, devendo o aplicador da norma utilizá-la com sensatez, de acordo com cada situação.

Basta sempre avaliar se o emprego de recurso público para a situação " $X$ " em concreto foi feito de forma adequada, necessária e proporcionalmente racional e razoável a cumprir a ordem jurídica.

Pelo exposto, estamos de acordo com Paulo Bonavides ao defender a necessidade do alastramento da utilização do presente princípio, nos seguintes termos: "Em nosso ordenamento constitucional não deve a proporcionalidade permanecer encoberta. Em se tratando de princípio vivo, elástico, prestante, protege ele o cidadão contra os excessos do Estado e serve de escudo à defesa dos direitos e liberdades constitucionais. De tal sorte que urge, quanto antes, extraí-lo da doutrina, da reflexão, dos próprios fundamentos da Constituição, em ordem a introduzi-lo, com todo o vigor no uso jurisprudencial"s1.

\subsection{Princípio da Razoabilidade}

A confusão feita entre o princípio da razoabilidade e da proporcionalidade é algo bastante comum, mesmo porque na prática é realmente uma tarefa bastante difícil distingui-los, sendo, justamente por esta simbiose, que a doutrina, muitas vezes, prefere tratá-los não em tópico apartado, mas de forma conjunta.

Esta confusão, aliás, não é à toa, pois trata realmente de institutos cujo grau de interpenetração é imenso.

Como temos afirmado desde o início deste trabalho, os princípios constitucionais não devem ser vistos como algo matemático e de forma isolada, como se cada um correspondesse a um número diferente. A razão dos princípios de Direito e do próprio

${ }^{51}$ BONAVIDES, Paulo. Curso de Direito Constitucional. 22a ed. São Paulo: Malheiros Editores, 2008, p. 434. 
Direito somente ocorre a partir do entendimento global desta principiologia constitucional, sendo entendida articuladamente, e sendo vistos os princípios, simultaneamente, como legítimos integrantes de uma mesma engrenagem constitucional.

E com o princípio da razoabilidade algo diferente não ocorre. Servindo também para direcionar a prática administrativa, mas especialmente para impor uma obrigatoriedade racional-sistêmica ao agir.

É importante afirmar que mesmos aqueles atos considerados pela doutrina como discricionários, não possui uma liberdade de forma abrangente em sua realização, pois estão sempre adstritos à legalidade e à constitucionalidade, encontrando genuínos limites e devendo ser praticados de acordo com a racionalidade sistêmica imposta pelo ordenamento jurídico.

Assim, o princípio da razoabilidade vem justamente para impor racionalidade, moderação, sensatez, regularidade, enfim, adequada harmonia na externalização de todos os atos administrativos, a se guiar pela sistemática social constitucionalmente ordenada. Pressupõe uma congruência da motivação e dos critérios utilizados pelo agente público no desempenho da função Administrativa.

Neste sentido, poderemos afirmar que o princípio da proporcionalidade acaba sendo uma decorrência do princípio da razoabilidade, vez que não podemos concebê-lo dissociado da razão e da racionalidade essencial a sua concretização. O princípio da razoabilidade traz a necessidade de haver uma real congruência lógica entre a motivação de agir e a atuação concreta da administração. Destacamos a peculiar importância do princípio em comento, já que entendemos ser o seu sentido nuclear, ao final, dar vida ao que conhecemos por justiça.

Mas, é ainda imprescindível dizer que o agir com razoabilidade não tem o mesmo significado que "a única forma de agir". Realmente, para as muitas das questões colocadas no interior da Administração Pública não há como defender que somente há uma forma de fazer as coisas. O que o referido princípio impõe é que os atos escolhidos dentro da zona da discricionariedade existente, a partir do rol de opções cabíveis para determinado caso, 
devem ser realizados com base em uma escolha política de como agir e esta escolha tem que ser racional, aceitável, razoável.

Alguns doutrinadores defendem a subjetividade deste princípio, culpam a falta de objetividade a dificultar sua aplicação. Mas como o nosso sentido aqui é de contribuir para a reflexão sobre a vida prática destes princípios, vamos simplesmente observar que se em alguns - e raros - casos há uma dificuldade de visualizar com clareza a linha limítrofe entre o razoável e o irrazoável, na prática cotidiana o irrazoável salta aos olhos no que diz respeito à administração e ao emprego do recurso público, sendo assim, por que não começarmos a pleitear a anulação dos diversos atos praticados que são visivelmente irracionais, irregulares, irrazoáveis, inaceitáveis aos olhos constituintes e injustos e imorais, conforme preceitua o ordenamento pátrio?

\section{O CONTROLE DA MORALIDADE}

O nosso olhar neste trabalho está no sentido de trazer a preocupação da imoral malversação do dinheiro público, aproveitando para alertar sobre os perigos da retórica moralista, que diz pretender acabar com o mal da "corrupção" (em seu sentido mais amplo possível conhecido socialmente) punindo "exemplarmente" indivíduos. A prática imoral no interior do Estado certamente não cessará com a prisão de uma ou outra pessoa aqui e ali, a exemplo do recente caso da prisão do governador do Distrito Federal, José Roberto Arruda, pois o que se televisiona e aparece neste sentido é só a ponta do iceberg, e certamente há um longo e histórico rastro que este episódio televisivo não mostrará. E será que com esta prisão o DF está de uma vez por todas livre da corrupção? Estamos certos de que não. Sabemos que a imoralidade administrativa não é algo ligado a pessoas individualmente, havendo todo um esquema destrutivamente imoral que permeia, com maior ou menor intensidade, a máquina do Estado e circunda o dinheiro público.

Muitas vezes ligam-se os holofotes diretamente para os grandes nomes da política, para os chefes do Executivo e parlamentares, de uma forma geral, mas temos possibilidades muito maiores de encontrarmos corriqueiramente o mal e desonesto uso do recurso público, se visualizarmos a rotina de ilustres nacionalmente desconhecidos nos 
Gabinetes parlamentares, nas Secretarias, nos Ministérios, nos Conselhos setoriais, daqueles que firmam contrato ou conveniam com o Poder Público.

Enfim, por todos os locais onde há vultosa e permanente lida com o dinheiro público, há um conjunto de infinitas possibilidades de utilizá-lo para promover um mesquinho jogo de poder em detrimento da sociedade. Portanto, é no aperfeiçoamento constante do aparelho estatal em paralelo com investimento numa maior interação da sociedade civil com o Estado que se poderá proteger definitiva e responsavelmente a coisa pública das más intenções das pessoas.

O nosso enfoque se resume ao lema de que a prevenção nos é socialmente mais benéfica e eficaz que simplesmente a repressão, ou como diria o velho ditado popular: "é melhor prevenir que remediar". Portanto, defendemos que haja uma maior preocupação política e social com as causas estruturais e institucionais relacionadas ao mau uso do dinheiro público, e neste sentido os casos individuais, se quisermos mesmo extirpar este mal, são bastante importantes e exemplares, mas para aproveitarmos os reajustes verificados no caso concreto e readequarmos constantemente o que possibilita a disfunção estatal.

A radicalização na transparência das ações estatais também é um grande aliado nesta batalha, pois o sigilo e a desinformação do que está e do como está se fazendo é um verdadeiro inimigo social e um majestoso convite à má e desonesta administração do nosso dinheiro.

Devemos centrar sérios e eficazes esforços para tentar diminuir a distância existente entre o Brasil legal e o Brasil real, para o que precisamos primeiramente desmistificar que a despreocupação social e o "querer se dar bem" não é algo inerente da classe política, de que não está enraizada em todos os governos e em todos os lugares, para consequentemente fomentarmos a indignação social com tais práticas no interior do Estado. Não é uma tarefa fácil, reconhecemos, pois pressupõe sérias preocupações e esforços educacionais, culturais e, sobretudo, políticos.

Certamente que a preocupação em zelar pelo bem público e cumprir as expectativas sociais não é algo novo, tanto que historicamente há esforços, inventando e aprimorando 
mecanismos aptos para controlar o abuso e o desvio da finalidade no interior da administração. Aliás, podemos perceber que tanto a criação quanto o aperfeiçoamento e a interação dos institutos de controle estão diretamente relacionados com o desenvolvimento do sistema democrático, pois quanto maior um, maior e melhor se faz o outro. Assim, podemos ver hoje em funcionamento uma série de mecanismos de controle do arbítrio e da má-fé no interior do Estado, inimaginável há pouco tempo. E para conhecermos alguns elementos políticos que têm o escopo de garantir a integridade estatal é que reservamos o presente capítulo.

\subsection{Mecanismos de Controle Interno e Externo}

Controlar não é sinônimo de exterminar, são maneiras de manter o equilíbrio da relação estado- sociedade. E os mecanismos de controle existem para garantir o equilíbrio interno na Administração Pública, refreando os desajustes, contribuindo, enfim, para que o Estado cumpra adequadamente suas finalidades em cada um dos três Poderes estabelecidos.

O legislador constituinte, como não podia deixar de ser, também se preocupou com a promoção do controle dos gastos públicos, e para tanto destinou um tópico específico destinado a regulamentar os parâmetros para a fiscalização contábil, financeira e orçamentária da Administração Pública.

Assim, foram criados dois tipos de mecanismos a partir da Constituição de 1988: o Controle Interno, realizado internamente por cada um dos Poderes, e o Controle Externo, realizado pelo Poder Legislativo, auxiliado pelo Tribunal de Contas.

Primeiramente é importante frisar que o parágrafo único, do art. 70, da $\mathrm{CF}$, determina a obrigatoriedade de qualquer pessoa física ou jurídica, pública ou privada, que se utilize ou que arrecade, guarde, gerencie ou administre dinheiros, bens e valores públicos, em prestar contas de seus atos.

Em relação ao controle interno, devemos dizer que se trata daquele exercido internamente pelos Poderes Executivo, Legislativo e Judiciário, exigindo-se o art. 74, da 
$\mathrm{CF}$, que a manutenção destes controles seja feita de forma integrada e determinando que tenham como finalidade:

a) avaliar o cumprimento das metas previstas no PPA, assim como a execução dos programas de governo e dos orçamentos da União;

b) comprovar a legalidade e avaliar os resultados, quanto à eficácia e eficiência, da gestão orçamentária, financeira e patrimonial realizada pelos órgãos e entidades da administração, bem como da aplicação de recursos públicos por entidades de direito privado;

c) exercer o controle das operações de crédito, avais e garantias, bem como dos direitos e haveres;

d) apoiar o controle externo no exercício de sua missão institucional.

Deste mandamento constitucional podemos perceber e frisar a amplitude fiscalizatória dos mecanismos de controle existentes internamente em cada Poder. Pois, não basta averiguar em que e para que se gastou dinheiro público, isto deve ser feito para cumprir, primeiramente, um planejamento governamental estipulado pelo plano plurianual, portanto podemos perceber que gastos feitos de forma desatrelada a este planejamento já apontam fortes indícios de irregularidade. Aliás, o quantum foi gasto deve ser controlado e avaliado pelos resultados esperados e alcançados, sempre atrelados à análise da eficiência e da eficácia quando do uso de recurso público por quem quer que seja.

Podemos dizer que o mandamento constitucional orienta acertadamente a constituição e a atribuição dos mecanismos de controle interno para garantir a moralidade no gerenciamento do recurso público. No entanto, sabemos que em muitos aspectos há certo distanciamento quanto à norma e à prática administrativa, e neste aspecto especialmente está estabelecido um ideal social a ser buscado, mas ainda bem distante dos controles internos instituídos no Brasil, principalmente dos atrelados aos Poderes Executivos, especialmente os de âmbito municipal. Isto porque é vigente em grande parte dos municípios uma indevida regulamentação de tais mecanismos de controle, cuja falha ocasiona uma séria desestabilização das administrações municipais, muitas vezes conduzidas sem diretrizes, metas e objetivos claros e precisos, o que provoca sérias e perigosas brechas ao mau uso do recurso público. 
Todavia, em caso de conhecimento de qualquer tipo de irregularidade, no que se inclui por certo a imoralidade administrativa, os responsáveis pelo controle interno deverão acionar o Tribunal de Contas, dando ciência da situação, sob pena de responsabilidade solidária em caso de omissão ${ }^{52}$.

É importante ressaltar que nos casos em que há a verificação de irregularidade, não é de competência exclusiva dos controles internos promover o acionamento do Tribunal de Contas, podendo também fazê-lo a sociedade civil organizada, por intermédio de partido político, associação ou sindicato, ou qualquer cidadão que perceba ou tome ciência da patifaria administrativa.

Quanto ao controle externo, este será realizado pelo Poder Legislativo em conjunto com o Tribunal de Contas, destinando-se basicamente a averiguar a probidade dos atos da administração, a regularidade dos gastos públicos e do emprego de bens, valores e dinheiros públicos, e a fiel execução do orçamento. Em relação ao controle externo, a Constituição trata-o mais detalhadamente em seu art. 71.

Como observa Antonio Roque Citadini: "Em algumas nações aparecendo como órgão colegiado (Tribunal de Contas), em outras de forma unipessoal (Controladorias), os órgãos de controle das contas públicas têm nos dias atuais a importante e indispensável tarefa de fiscalizar as receitas e despesas dos Estados. Os Tribunais ou Controladorias são hoje presenças relevantes nos Estados modernos, sendo tanto maior seu destaque quanto maior for o avanço de suas instituições democráticas" ${ }^{53} 54$.

Assim, podemos perceber a criteriosidade e a importância das atribuições constitucionalmente previstas para o Tribunal de Contas, por tal razão o trataremos melhor a seguir.

\footnotetext{
52 "Em grande número de países os órgãos de controle interno funcionam como instrumento de apoio para o controle externo, devendo denunciar ao Tribunal ou Controladoria qualquer irregularidade ou ilegalidade detectada. Parte do controle interno - especialmente nas empresas privadas de auditoria contratadas pelo Estado, sendo, em alguns países, executada diretamente por órgão da área de finanças. Nos dias atuais ocorre - cada vez em maior número de países - uma interação entre os fiscalizadores externos e os internos, tanto na aplicação de normas e técnicas de auditorias comuns, como no apoio dado aos Tribunais e Controladorias". (CITADINI, Roque Antonio. O controle externo da Administração Pública. São Paulo: Editora Max Limonad, 1995, p. 94).

${ }_{53}^{53}$ Idem, Ibidem, p. 13.

${ }^{54} \mathrm{O}$ Sistema de Tribunais de Contas é predominante na Europa Continental, nos países de influência francesa e portuguesa. O Sistema de Controladoria predomina nos países de tradição inglesa.
} 


\subsection{Tribunal de Contas}

As primeiras formas de controle dos atos financeiros da Administração Pública, surgiram ainda na fase embrionária da organização do Estado, nas antigas Roma e Grécia.

No ano de 1714, e com o escopo de evitar o descontrole no gasto do dinheiro do Rei Frederico Guilherme I, da Prússia, o Tribunal de Contas apareceu no cenário mundial $l^{55}$.

No Brasil colonial, as Juntas das Fazendas das Capitanias e a Junta da Fazenda do Rio de Janeiro, submetidas a Portugal, iniciaram a história do Tribunal de Contas. Em 1890, Rui Barbosa, à época Ministro da Fazenda, redigiu o Decreto n..$^{\circ}$ 966-A, que instituiu o Tribunal de Contas da União, com a competência para examinar, revisar e julgar todas as operações relacionadas com as finanças públicas.

A partir de então, significativos avanços ocorreram, mas com a Constituição de 1937, o Tribunal de Contas caiu no esquecimento, ressurgindo no cenário nacional, somente com a Constituição de 1946.

O golpe militar e a Constituição de 1967, ocasionou a perda de suas competências, com a supressão de suas atribuições. A partir da promulgação da atual Constituição, o Tribunal de Contas teve sua jurisdição e competências ampliadas, recebendo poderes para fiscalização contábil, orçamentária e patrimonial.

No Brasil, dada a grande uniformidade, os Tribunais de Contas dos Estados e dos Municípios seguem o modelo federal.

Nos dizeres de Aliomar Baleeiro: "O Tribunal de Contas, no Brasil, é o órgão que se manifesta, não só no interesse da moralidade administrativa, mas também no da preservação dos objetivos pretendidos pelo Congresso quando autorizou despesas e receitas" $"$.

\footnotetext{
${ }^{55}$ Recebeu inicialmente a nomenclatura de Controladoria Geral de Contas.

${ }^{56}$ BALEEIRO, Aliomar. Uma Introdução à Ciência das Finanças. 14 ${ }^{\mathrm{a}}$ ed. rev. e atual por Flavio Bauer Novelli. Rio de Janeiro: Forense, 1995, p. 419.
} 
Os Tribunais de Contas auxiliam o Poder Legislativo no controle sobre os atos não só do Executivo, mas também do Judiciário sempre no que se referir à administração de recurso público, desempenhando, destarte, controle externo. Auxiliam o Legislativo, igualmente, no controle sobre sua própria administração no tocante à gestão dos recursos públicos, no que se tem controle interno.

Cabe destacar, entretanto, que os referidos tribunais não integram a estrutura organizacional do Legislativo, pois que, ainda que funcionem como órgãos auxiliares de tal poder, possuem autonomia constitucionalmente fixada ${ }^{57}$.

A função desempenhada pelos Tribunais de Contas não é jurisdicional, mas sim técnico-administrativa. Com efeito, todas as suas decisões podem ser revistas pelo Poder Judiciário, ex vi do artigo $5^{\circ}, \mathrm{XXXV}, \mathrm{CF} / 88$.

O controle externo que cumpre ao Congresso Nacional levar a efeito com auxílio do Tribunal de Contas da União engloba a fiscalização contábil, financeira, orçamentária, operacional e patrimonial da União e das entidades da administração direta e indireta, no que tange não só à legalidade, mas também no que se refere à legitimidade, economicidade, aplicação das subvenções e renúncia de receitas. Como se nota do artigo 70, parágrafo único, da Constituição Federal, o controle em tela abrange, além dos Poderes da República, qualquer pessoa física ou jurídica, pública ou privada, que utilize, arrecade, guarde, gerencie ou administre dinheiro, bens e valores públicos ou pelos quais a União responda, ou que, em nome desta, assuma obrigações de natureza pecuniária.

Conforme vimos no artigo 71, variadas são as tarefas desempenhadas pelos Tribunais de Contas, as quais são classificadas por Maria Sylvia Zanella Di Pietro como funções de fiscalização financeira; de consulta; de informação; de julgamento; sancionatórias; corretivas; de ouvidor ${ }^{58}$.

Dentre tais atribuições se destacam: o oferecimento de parecer prévio sobre as contas prestadas pelo chefe do Executivo; o julgamento das contas dos agentes públicos e administradores de dinheiros, bens e valores públicos; a aplicação das sanções previstas em

57 “O Tribunal não é preposto do Legislativo. A função que exerce, recebe-a diretamente da Constituição, que lhe define as atribuições” (STF - Pleno - j. 29.6.84, in RDA 158/196).

${ }^{58}$ Idem, ibidem, p. 687-688. 
lei aos responsáveis, em caso de ilegalidade de despesa ou irregularidade de contas; a fiscalização de repasses de recursos efetuados entre as entidades públicas (União, Estados, Distrito Federal e Municípios); a realização de inspeções e auditorias de natureza contábil, financeira, orçamentária, operacional e patrimonial, nas unidades administrativas dos três Poderes, nas administrações direta e indireta.

De regra a atuação dos Tribunais de Contas se desempenha a posteriori, não encontrando guarida constitucional qualquer controle prévio sobre os atos ou contratos da Administração direta ou indireta, nem sobre a conduta de particulares que tenham a seu cargo a gestão de dinheiros, bens ou valores públicos. No entanto, uma clara exceção a tal regra é merecedora de destaque e diz respeito às inspeções ou auditorias in loco, que podem ser realizadas a qualquer tempo. De fato, outras pequenas exceções podem ser encontradas na Lei de Licitação (exame prévio dos editais) e na Lei Complementar n. ${ }^{\circ}$ 101/2.000.

Vale salientar que as normas sobre fiscalização contábil, financeira e orçamentária previstas para o TCU aplicam-se aos órgãos correspondentes nas esferas estadual e municipal, valendo, destarte, o princípio da simetria constitucional. Entretanto, algumas particularidades são encontradas no âmbito municipal.

No tocante aos Municípios, Maria Sylvia Zanella Di Pietro, destaca que: “o artigo 31 da Constituição prevê o controle externo da Câmara Municipal, com auxílio dos Tribunais de Contas dos Estados ou do Município ou dos Conselhos ou Tribunais de Contas, onde houver. Pelo $\S 2^{\circ}$, o parecer prévio emitido pelo órgão competente sobre as contas anuais do Prefeito só deixará de prevalecer por decisão de $2 / 3$ dos membros da Câmara Municipal. E o $\S 3^{\circ}$ contém uma inovação, ao determinar que as contas dos Municípios ficarão durante 60 dias, anualmente, à disposição de qualquer contribuinte, para exame e apreciação, o qual poderá questionar-lhe a legitimidade, nos termos da lei. É mais uma hipótese de participação popular no controle da Administração"59.

Devemos destacar que, no controle externo, o Tribunal de Contas ${ }^{60}$ possui poderes especiais para impor correções à Administração, bem como para intervir em licitações, podendo, ainda, aplicar sanções, como multas ou, dependendo da gravidade, até decretar a

${ }^{59}$ Idem, ibidem, p. 689.

${ }^{60} \mathrm{O}$ poder de responsabilização é de extremamente relevante. Os Tribunais de Contas, se comparado aos outros países, têm poderes enormes para responsabilizar administradores. 
penhora de bens e a inelegibilidade do responsável. Eis uma considerável distinção deste controle, que somente é possível por ser autônomo e independente da Administração, o que o difere essencialmente do controle interno, por ser parte integrante da Administração, e por isto encontra-se subordinado a ela, contendo um caráter somente consultivo e opinativo, e significa o mesmo que dizer não determinante.

Esta diferenciação não denota, no entanto, a depreciação deste ou daquele mecanismo, apenas significando que incidem de forma diferente. Tanto os mecanismos de controle interno, quanto os de controle externo são essencialmente importantes socialmente, mas acreditamos que somente a articulação dentre todos eles é que de fato possibilitará um efetivo controle da corrupção na esfera pública brasileira.

Neste diapasão, Ricardo Lobo Torres assevera: “o Tribunal de Contas está essencialmente ligado aos direitos fundamentais, aparece na Constituição Federal de 1988 como uma das garantias institucionais da liberdade, a que o cidadão tem acesso através das garantias processuais" e depois conclui: "espera-se que os Tribunais de Contas assumam o controle da economicidade e da legitimidade da execução orçamentária e que os contribuintes, no exercício da cidadania, deflagrem os mecanismos de fiscalização popular previstos na CF $88^{, 6162}$.

\subsection{Controle Social}

O controle externo não é feito somente pelos Tribunais de Contas e pelo Poder Legislativo, pois ele também pode e deve ser exercido pela própria sociedade civil, no exercício do chamado "controle social", com plena legitimidade, embora não necessariamente institucionalizado e formalizado.

O grau deste controle, como já foi dito, está relacionado ao grau de adequação democrática do Estado e, para refletir acerca do nível desta graduação, é que dedicaremos este tópico.

\footnotetext{
${ }^{61}$ TORRES, Ricardo Lobo. O Orçamento na Constituição. Rio de Janeiro: Renovar, 1995, p. 279-295.

${ }^{62}$ Esta esperança só ocorrerá quando todos os Tribunais de Contas do Brasil, sem exceção, produzirem decisões a respeito das prestações de contas, em um curto prazo, pois do contrário restará inviabilizada a responsabilização dos agentes públicos, que muitas vezes falecem antes das decisões ou os recursos desviados não são mais encontrados.
} 
Ainda que não seja necessária a institucionalização deste controle, é crucial para sedimentar o processo democrático no território nacional que os entes federativos (União, Estados e Municípios), neste estágio civilizatório, tragam a regulamentação formal, garantindo o seu mais amplo exercício.

Ademais, não podemos desatrelar as reais possibilidades do controle social com a qualidade da transparência das informações estatais ofertadas, pois quanto mais bem informada é a sociedade, melhor será exercido o controle sobre os atos administrativos.

Embora já tenhamos tratado desta questão em tópico específico, quando da análise do princípio da publicidade, vale a pena relembrar que a transparência das informações extrapola a mera publicidade, pois para esta basta que esteja alocada em local público, enquanto o cumprimento daquela se satisfaz com a real democratização das informações disponibilizadas, o que requer uma descodificação da tecnicidade que permeia as informações a respeito da execução orçamentária, além de viabilizar o fácil acesso a todos os cidadãos, respeitadas as diferenças culturais e sociais. Assim, a transparência das ações estatais está muito mais ligada à qualidade das informações disponibilizadas do que com o seu mero acesso.

Logo, deve haver o comprometimento incondicional do Estado em manter sempre aberto a toda sociedade civil o acesso aos seus bancos de dados e às informações gerenciais, de qualquer um de seus órgãos.

Neste sentido, a prestação de contas pelo Poder Público é de suma importância para abastecer o controle social de informações necessárias ao seu exercício.

Com a edição da Lei de Responsabilidade Fiscal, no ano de 2000, a prestação de contas sobre todas as formas de gestão da coisa pública passou a ser obrigatória.

Para tanto, foram instituídos novos mecanismos e instrumentos de controle social sobre as ações do Estado, ou as realizadas em nome dele. Um importante fruto deste reordenamento institucional foram as controladorias, que estão a funcionar de modo a contribuir com o aprimoramento democrático da Administração Pública em todo o país. Um bom exemplo disto diz respeito à ação da Controladoria Geral da União (CGU) que, a 
partir de 2003 passou a submeter as administrações públicas municipais a uma rigorosa fiscalização de seus processos de orçamentos e de gestão, por meio da realização de sorteios semanais.

Consideramos esta ação bastante acertada se comparada à ação dos Tribunais de Contas, que em sua prática cotidiana exercem ações essencialmente ex-post, vez que analisam as contas públicas apenas e somente após encerrado o ano de sua execução. Assim, merece destacar o acerto da ação narrada da CGU por privilegiar uma ação preventiva, a qual é socialmente preferível, exercida ao controlar a gestão ainda em andamento contra o desperdício estatal e o inadequado uso do dinheiro público.

Há, ainda, outro importante instrumento de controle social sobre os desajustes do emprego do recurso público, preceituado no parágrafo $3^{\circ}$, do artigo 165 , da Constituição Federal: os Relatórios Resumidos da Execução Orçamentária, que devem ser publicados com o prazo de até 30 (trinta) dias após o encerramento de cada bimestre.

Embora entendamos que no caso de dispêndio de dinheiro público é melhor prevenir que remediar, observa-se que no Brasil os mecanismos de controle social são feitos muito mais posteriormente que preventivamente, e assim também o são, em regra, as prestações de contas, ou seja, resumem-se em instrumentos retrospectivos das ações estatais, ao invés de serem realizadas de forma a permitir o controle social durante todo o processo de gestão pública. Eis mais uma prova de um sério enodoamento burocrático que requer aprimoramento.

A burocracia estatal é sem dúvidas uma das grandes inimigas da radicalização do processo democrático por um lado e, por outro, demonstra ser uma das grandes amigas da imoralidade administrativa. Portanto, vale substancialmente voltarmos os olhos à estrutura político-institucional do Estado para promover o seu constante aprimoramento democrático.

Pela primeira vez na história de nosso país uma Constituição prevê o exercício direto do poder do Estado pelo povo (art. $1^{\circ}$, parágrafo único), pois todas as outras previam-no apenas indiretamente, por intermédio de representantes. Esta possibilidade constitucional, no entanto, ainda é significantemente desconhecida e limitada - para não 
dizer inexistente ${ }^{63}$ - em relação ao poder de dizer como deverá ser aplicado o produto fruto da arrecadação tributária. Isto reflete uma significante perda social, pois as prioridades estatais em discordância com prioridades e reais necessidades do povo significam, ao final, um descumprimento da finalidade estatal consistente no atendimento aos interesses verdadeiramente sociais - e não governamentais.

$\mathrm{Na}$ prática os processos orçamentários são realizados ano a ano na base das disputas e dos acordos políticos, dos quais infelizmente os legítimos interessados têm ficado historicamente distantes. Claro que muito mudou, mas ainda há o que mudar no sentido de promover a readequação democrática do Estado, especialmente voltada a viabilizar ao máximo o exercício da democracia direta ou participativa. Pois, afinal, quanto mais democrático é o Estado, mais acertadas tendem a ser suas decisões de forma a realmente combaterem os problemas, refletir e proverem as verdadeiras necessidades sociais.

Este caminho não é fácil nem curto, mas os grandes problemas que precisam ser seriamente enfrentados gradualmente são, ao nosso ver, basicamente dois: educacional e vontade política.

\subsection{Controle Judicial}

Dentre as formas de controle exercidas no plano jurisdicional sobre a atividade administrativa do Estado, podemos destacar dois importantes instrumentos sociais: a Ação Popular e a Ação Civil Pública.

\subsubsection{Ação Popular}

Por meio da Ação Popular é possível pleitear a anulação ou a declaração de nulidade de atos lesivos ao patrimônio público ou de entidade da qual o Estado participe, à

${ }^{63}$ Afirmamos a inexistência da participação popular na elaboração orçamentária, pois embora haja, por obrigatoriedade legal, audiências públicas no momento desta construção, estas vêm sendo realizadas na prática apenas e exclusivamente para cumprir um requisito formalmente necessário para legitimar o processo. Isto porque, além do esvaziamento da população interessada nestas audiências, muitas vezes ocupadas apenas pelos assessores técnicos e políticos do Executivo e do Legislativo, há uma generalizada desconsideração da real vontade do povo quando do estabelecimento das prioridades e das metas governamentais espelhadas no orçamento. 
moralidade administrativa, ao meio ambiente e ao patrimônio histórico e cultural, conforme se extrai do artigo $5^{\circ}$, LXXIII, CF/88. A ação em destaque se encontra regulada pela Lei n. ${ }^{\circ} 4.717 / 65$.

A legitimidade ativa para a propositura da ação popular foi conferida a qualquer cidadão no gozo de seus direitos políticos, pelo que se tem por excluídos os estrangeiros, as pessoas jurídicas, o Ministério Público, assim como os brasileiros que tiverem suspensos ou perdidos seus direitos políticos.

Além da qualidade de eleitor exigida do postulante, Hely Lopes Meirelles elenca como requisitos para o ajuizamento da Ação Popular a ilegalidade ou ilegitimidade do ato impugnado e a lesividade do ato ao patrimônio público ${ }^{64}$. Acrescentando, ainda, que "embora os casos mais freqüentes de lesão se refiram ao dano pecuniário, a lesividade a que alude o texto constitucional, tanto abrange o patrimônio material, quanto o moral, o estético, o espiritual, o histórico." ${ }^{65}$.

A ação em debate, tanto pode ser ajuizada com finalidade preventiva ou repressiva, isto é, tanto antes da produção dos efeitos lesivos, como depois de tais já consumados.

Conforme a lição de da professora Di Pietro, dupla é a natureza da Ação Popular. Possui natureza constitutiva por se pleitear do órgão jurisdicional a anulação do ato lesivo. Por outro lado, apresenta, outrossim, natureza condenatória, pois que se objetiva a condenação dos responsáveis ao pagamento de perdas e danos ou à restituição de bens e valores, ex vi do artigo $14, \S 4^{\circ}$, da Lei n. ${ }^{\circ} 4.717 / 65^{66}$.

Destacamos a Ação Popular como um importante instrumento social para garantir e restabelecer a moralidade na Administração Pública, podendo perceber a sua preciosidade diante da norma constitucional e da lei que a trata especialmente. Embora apontemos aqui este instrumento de forma breve, deixamos o indicativo de sua significância social e fazemos um apelo à sociedade civil para que usufrua melhor deste poder constitucionalmente assegurado e destinado a fortalecer o seu controle social, utilizando de

\footnotetext{
${ }^{64}$ MEIRELLES. Mandado de Segurança., Ação Popular e Ação Civil Pública. $11^{\mathrm{a}}$ ed. São Paulo: Editora Revista dos Tribunais, 1987, p. 85.

${ }^{65}$ Idem, Ibidem, p. 85-86.

${ }^{66}$ Idem, Ibidem, p. 734.
} 
forma abrangente e constante este instrumento de forma a contribuir com o restabelecimento da moralidade administrativa no trato da coisa pública.

\subsubsection{Ação Civil Pública}

Constitui meio processual dirigido à tutela do meio ambiente, do consumidor, dos bens e direitos de valor artístico, estético, histórico, turístico e paisagístico, de quaisquer outros interesses difusos e coletivos, da ordem econômica e da economia popular, além da ordem urbanística. Com efeito, este estudo se restringirá ao exame dos aspectos desse instituto, que se encontra disciplinado pela Lei n. ${ }^{o} 7.347 / 85$, no que concernente ao controle da Administração Pública.

No artigo $5^{\circ}$ desta norma, encontra-se o rol de legitimados para a proposição de Ação Civil Pública, e respectiva cautelar, destacando-se o papel do Ministério Público e, especialmente, de associações da sociedade civil instituídas há mais de um ano, como legitimados ativo na proteção do patrimônio público e social, que, de fato, representa uma das mais importantes dimensões do controle jurisdicional da atividade administrativa, mormente no que se refere aos atos de improbidade administrativa, dentre os quais se situam as condutas que menoscabam o princípio da moralidade. Aos membros do parquet é ainda atribuída, com exclusividade, a presidência do inquérito civil, o qual consubstancia procedimento administrativo, de natureza investigatória e inquisitiva, apto a fornecer elementos necessários para a proposição de eventual ação civil pública, bem como para a viabilização de recomendações para o Poder Público.

O Ministério Público está também investido da competência para tomar o compromisso de ajustamento de conduta nas hipóteses cabíveis, de sorte a se configurar um instrumento com eficácia de título executivo que confere àquele que o formalizou, em se processando o descumprimento da obrigação assumida pela pessoa responsável pelo dano ou ameaça a interesse difuso ou geral, a possibilidade de ajuizar ação de execução. 


\section{A RESPONSABILIDADE DO ESTADO PELA TRANSGRESSÃO AO PRINCÍPIO DA MORALIDADE}

\subsection{Regime Jurídico Brasileiro}

O ordenamento jurídico brasileiro abraçou a tese da responsabilidade civil do Estado na Constituição Federal, artigo 37, § 60: "o Estado responderá pelos danos que seus agentes, nesta qualidade, causarem a terceiros", independentemente de dolo ou culpa, uma vez que esta só terá importância para estabelecer o direito de regresso do Estado contra o seu agente.

A consagração da responsabilidade civil do Estado constitui-se em imprescindível mecanismo de defesa do indivíduo face ao Poder Público.

Mediante a possibilidade de responsabilização, o cidadão tem assegurada a certeza de que todo dano a direito seu ocasionado pela ação de qualquer funcionário público no desempenho de suas atividades será prontamente ressarcido pelo Estado.

Entretanto, é importante destacar que um longo período de amadurecimento teórico foi necessário para que o atual quadro se pudesse consolidar. Abaixo, serão rapidamente pontuadas as principais teorias adotadas ao longo da evolução do tratamento conferido à responsabilidade civil do Estado. 
A Teoria da Irresponsabilidade prevaleceu durante os governos absolutos, tendo como principal fundamento a ideia de Soberania. Não se considerava concebível que o rei, representante do Estado e titular de poderes incontrastáveis, pudesse lesar os seus súditos. Responsabilizar o Estado por danos seria o mesmo que nivelá-lo aos súditos, tendo em menoscabo a sua soberania.

Com a superação da teoria da irresponsabilidade, passou-se a adotar os princípios do direito civil, apoiados no conceito de culpa, para responsabilizar o Estado. Conforme a Teoria da Responsabilidade com Culpa, impunha-se a responsabilidade pelos atos de gestão levados a efeito pelo Estado, pois que nesses Estados os particulares funcionariam em regime de igualdade. Por outro lado, não caberia a responsabilização pelos atos império, é dizer, pelos atos em que o Estado desempenhasse prerrogativa associada à manutenção da ordem e do bem comum. No entanto, de grande dificuldade prática se mostrava a tarefa de distinguir as duas situações apontadas, o que provocou o desenvolvimento das chamadas teorias publicistas, as quais preconizam a responsabilidade civil do Estado independentemente de culpa deste ou de seus prepostos.

De acordo com a Teoria da Culpa Administrativa responde o Estado pelos danos impostos a terceiros sempre que houver culpa no serviço, seja pela sua inexistência (não prestação do serviço), seja pela sua prestação deficiente.

Pela Teoria do Risco Administrativo se sustenta a responsabilidade estatal, a despeito de dolo ou culpa do agente, desde que comprovado o nexo de causalidade entre a ação ou omissão do Estado e o dano experimentado pela vítima, admitindo-se, entretanto, excludentes e atenuantes de responsabilidade (v.g., culpa da vítima).

Já a Teoria do Risco Integral impõe ao Estado, independentemente de dolo ou culpa, a obrigação de indenizar os danos sofridos por terceiros, não cabendo a oposição de qualquer excludente ou atenuante de responsabilidade.

Como já salientado, dispôs a Constituição, em seu art. 37, § $6^{\circ}$ que: “As pessoas jurídicas de direito público e as de direito privado prestadoras de serviços públicos 
responderão pelos danos que seus agentes, nessa qualidade, causarem a terceiros, assegurado o direito de regresso contra o responsável nos casos de dolo ou culpa".

Esse comando representa a fixação no direito pátrio, da responsabilidade extracontratual do Estado na modalidade risco administrativo. Com efeito, está fixada a responsabilidade objetiva do Estado pelos danos que seus agentes causarem a terceiros, prescindindo-se de dolo ou culpa, sendo para tanto suficiente a demonstração do nexo de causalidade entre a ação ou omissão estatal e o dano havido pela vítima. Em favor do Estado se afigura a ação regressiva contra o agente, desde que comprovado que este tenha agido com dolo ou culpa, já que sua responsabilidade é subjetiva.

Sintetiza o eminente Professor Edmir Netto de Araújo que: "o problema da responsabilidade do Estado por atos ou omissões prejudiciais de seus agentes, ou por fatos e coisas à sua guarda, é equacionado em termos eminentemente objetivos, sendo o administrado dispensado do ônus probante quanto à culpabilidade direta ou indireta da Administração"67.

Assim, relacionando o tema à responsabilidade civil do Estado, podemos afirmar que se a imoralidade administrativa verificada quando da administração do recurso público ocasionar dano, material ou moral, aos cidadãos, poder-se-á responsabilizar civilmente o Estado, tendo este o legítimo direito ao regresso, vez que atos desonestos, improbos e imorais não são praticados descolados do dolo ou da culpa.

\subsubsection{Causas Excludentes e Atenuantes de Responsabilidade}

Ao examinar o tema, Maria Sylvia Zanella Di Pietro destaca que: "sendo a existência do nexo de causalidade o fundamento da responsabilidade civil do Estado, esta deixará de existir ou incidirá de forma atenuada quando o serviço público não for a causa do dano ou quando estiver aliado a outras circunstâncias, ou seja, quando não for a causa única"68. Nesse diapasão se apresentam as causas excludentes e atenuantes da responsabilidade extracontratual do Estado, a qual iremos trazer neste trabalho somente a

${ }^{67}$ ARAÚJO, Edmir Netto de. Curso de Direito Administrativo. $3^{\text {a }}$ ed. São Paulo: Editora Revista, 2007, p. 748.

${ }^{68}$ Idem, Ibidem, p. 602. 
título de curiosidade, vez que não é aplicável em caso de desrespeito à moralidade administrativa, como veremos.

São causas excludentes da responsabilidade, a força maior e a culpa exclusiva da vítima.

Por força maior pode-se entender os fatos imprevisíveis e inevitáveis, que fogem ao controle do Estado e das pessoas, em face do qual não há que se falar em responsabilidade estatal. Como exemplos podem ser apontados os terremotos, as inundações, etc. Nesses casos inexiste nexo de causalidade entre a atuação da Administração e os possíveis danos havidos por terceiros.

Para determinar os efeitos da culpa da vítima é necessário examinar se o caso é de culpa exclusiva da vítima ou de culpa concorrente. Com efeito, na primeira hipótese tem-se por inexistente o nexo causal entre a atuação do Estado e o dano suportado pela vítima, com a consequente exclusão da responsabilidade estatal. Porém se o Estado e o lesado concorreram para a produção do resultado danoso, vislumbra-se a atenuação da responsabilidade que tocaria ao Poder Público, arcando a vítima com parte dos prejuízos havidos. Acrescente-se que também exclui a responsabilidade do Estado a demonstração de que o dano adveio de ato de terceiro, por conta do não comparecimento no necessário nexo causal entre a efetivação do dano e a conduta da Administração.

Claro que em caso de comprovada imoralidade administrativa, por tudo o que expusemos em nosso trabalho, não há como arguir excludentes ou atenuantes de responsabilidade, pois a imoralidade administrativa está relacionada a um ato praticado voluntária e conscientemente no intuito de desviar a coisa pública de sua genuína finalidade. Portanto, afasta-se de pronto a culpa exclusiva do outro que não a do agente público, o caso fortuito ou a força maior.

\subsubsection{Reparação do Dano}

A reparação do dano causado pela Administração a terceiros pode se processar por via administrativa ou por via judicial. 
$\mathrm{Na}$ forma administrativa, cumpre ao lesado formular reclamação administrativa, com pedido de indenização em face do órgão competente da pessoa jurídica responsável. Destarte, estará instaurado o correspondente processo administrativo, com ampla defesa e contraditório assegurados às partes.

Não se realizando a reparação dos danos no âmbito administrativo, poderá o prejudicado propor ação de indenização contra a pessoa jurídica que deu causa ao dano.

Conforme leciona Edmir Netto de Araújo, "a existência de dano indenizável, quantificado e detalhado em sua expressão econômica, é requisito indispensável para a reparação do prejuízo decorrente da lesão que empenha a responsabilidade civil do Estado, pois consistindo tal reparação em obrigação de indenizar, é obvio que esta não pode se efetivar quando não há o que reparar"69.

No mesmo sentido, José Cretella Júnior, pondera: "Demonstrada a ocorrência de qualquer causa excludente de responsabilidade, fica isento o Estado e indenizar. Interferindo culpa integral da vítima, o Estado é irresponsável; havendo culpa parcial, repartem-se os prejuízos proporcionais" ${ }^{\text {,70. }}$.

Com efeito, o dano indenizável deve ser consequência de ação ou omissão, coisas ou fatos atribuíveis ao Estado por nexo de causalidade, lícitos ou ilícitos, sem que compareçam causas excludentes de responsabilidade. Vale dizer que a indenização deve ser plena, abrangendo o dano emergente, o lucro cessante, os honorários advocatícios, a correção monetária e os juros de mora, se for o caso, além de demais despesas.

\subsection{Responsabilidade do Servidor Público}

Todo agente público, do Presidente da República ao mais humilde servidor, tem o dever jurídico e moral de fidelidade à instituição a que serve, ao seu país, ao Direito que consubstancia a organização da sociedade política, definindo os meios e os fins de interesse público a realizar.

\footnotetext{
${ }^{69}$ Idem, Ibidem, p. 755.

${ }^{70}$ CRETELLA JÚNIOR, José. O Estado e a obrigação de indenizar. São Paulo: Saraiva, 1980, p. 309. (itálicos do original).
} 
Como temos afirmado desde o início em nosso trabalho, o agente público, em seu cotidiano, deve se guiar pelo princípio da superioridade dos interesses públicos, não estando ele, ali, naquele papel para servir-se mas para servir toda a coletividade e, sobretudo, viabilizar os objetivos sociais constitucionalmente descritos.

Há claras descrições sobre o seu papel e a sua atribuição, além do que seus atos devem cumprir vivas diretrizes para alcançar as finalidades anteriormente delineadas e motivadas. Aliás, os meios que utiliza para tanto também devem guardar coerência e ter ressonância efetiva no que se busca. Durante todo o tempo em que se reveste da roupagem estatal, deve inarradável respeito aos princípios diretores de sua ação institucional.

Por tal razão, o servidor público, no exercício de suas funções se sujeita à responsabilidade civil, penal e administrativa.

\subsubsection{Responsabilidade Civil}

A responsabilidade civil é, via de regra, de ordem pecuniária, baseada no princípio geral de que aquele que causa dano a outrem é obrigado a repará- $1 \mathrm{o}^{71}$. Os requisitos para que se configure são os da responsabilidade civil em geral, quais sejam: ação ou omissão antijurídica, culpa ou dolo (e os casos em que a lei prevê responsabilidade objetiva ou presume a culpa), nexo de causalidade e, por fim, a ocorrência de um dano material ou moral.

Nas palavras de Odete Medauar, "o dano pode originar-se de conduta ou omissão que lese diretamente o patrimônio público ou redundem em prejuízos a terceiros, pago pelos cofres públicos"72.

Distinguem-se duas hipóteses para a responsabilidade civil do funcionário público: quando o dano é causado a terceiros e quando é causado ao Estado.

Na hipótese de ser causado a terceiros, incide o artigo 37, $\S 6^{\circ}$, da CF com todas as peculiaridades analisadas acerca da responsabilidade do Estado perante terceiros. Nesses

\footnotetext{
${ }^{71}$ Positivado no art. 186 do CC.

${ }^{72}$ Idem, Ibidem, p. 300.
} 
casos, o terceiro ingressa com ação contra o Estado que, por sua vez, tem direito de regresso contra o servidor, caso este tenha agido com dolo ou culpa, o que é evidente em caso de desrespeito ao princípio da moralidade.

Se o dano é causado ao Estado, sua responsabilidade é apurada pela própria Administração por meio de sindicância ou processo administrativo, o que não impede que interessados se socorram do Poder Judiciário.

A decisão administrativa é autoexecutória, como se depreende das normas estatutárias, vale dizer, a Administração desconta uma parcela dos vencimentos do funcionário estatutário mensalmente até que o dano seja reparado. Se o servidor for empregado público, o regime celetista só permitirá o desconto ${ }^{73}$ com a concordância do empregado, a não ser que se trate de dolo, como sabemos que o é quando presente e comprovada a desonestidade, a improbidade, a imoralidade da conduta.

Como referido, sempre que se discorre sobre responsabilidade civil, como regra geral, cogita-se de responsabilidade de ordem pecuniária. No entanto, é preciso salientar que também se desenrola perante a vara cível a ação de improbidade administrativa, a qual apresenta consequências mais gravosas do que a mera condenação a ressarcir os cofres públicos, como já visto no tópico referente à probidade administrativa.

Sucintamente retomando, os tipos de penalidades previstas na esfera cível, além da condenação pecuniária, podem ser extraídos do $\S 4^{\circ}$, do art. 37, da CF, a saber: “Os atos de improbidade administrativa importarão a suspensão dos direitos políticos, a perda da função pública, a indisponibilidade dos bens e o ressarcimento ao erário, na forma e gradação previstas em lei, sem prejuízo da ação penal cabível”.

Em virtude da extensão das punições aplicáveis, há quem defenda que a responsabilidade do servidor por atos de improbidade extrapola a simples responsabilidade civil, sendo, destarte, ao mesmo tempo, política (suspensão dos direitos políticos), administrativa (perda de função pública) e civil (indisponibilidade de bens).

\footnotetext{
${ }_{73}$ Deve-se atentar para o fato de os estatutos dos servidores não permitirem o desconto integral, a deixar o servidor sem nenhum vencimento. O estatuto estabelece limites, até que o servidor repare todo o prejuízo.
} 
Considerando a necessidade do agir moralmente consoante ao ordenamento jurídico vigente, para cumprir os fins sociais previstos, defendemos ser este tipo de responsabilidade a mais adequada no caso do mal e, de forma imoral, o uso do dinheiro público.

Assim, além de trazer a imposição de devolução do que nos foi desonestamente surrupiado, dissipado, desviado ou malversado, traz como sanção a possibilidade do infrator indispor dos seus bens, de ter os seus direitos políticos suspensos, ou de até mesmo ser extirpado para longe do Estado, perdendo definitivamente a função e os benefícios de que tirava proveito o mal agente público.

\subsubsection{Responsabilidade Penal}

A responsabilidade penal decorre da prática de crime ou contravenção penal relacionados ao exercício do cargo, função ou emprego público, configurando-se os chamados crimes funcionais. Sua apuração é de competência exclusiva do juízo penal, no âmbito do Poder Judiciário e com todas as peculiaridades deste ramo do direito, v.g., a verificação da tipicidade da conduta cumulada com a antijuridicidade, a impossibilidade de responsabilidade objetiva e o dano ou risco de dano ao bem jurídico tutelado.

Medauar acrescenta que "os agentes políticos podem incidir em crimes de responsabilidade, objeto de legislação específica: Lei n. ${ }^{\circ}$ 1.079/50 (impeachment) - Chefes do Executivo federal e estadual, Ministros de Estado, Ministros do STF, Procurador-Geral

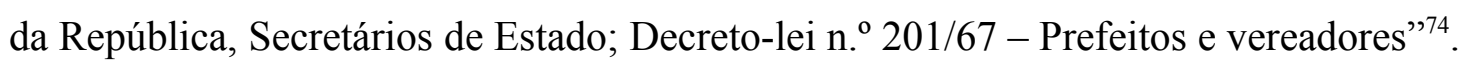

É importante destacar que o conceito de funcionário público utilizado no Código Penal é mais amplo, podendo ser equiparado ao de agente público ${ }^{75}$ :

\footnotetext{
${ }^{74}$ Idem, Ibidem, p. 299.

75 “Art. 327 - Considera-se funcionário público, para os efeitos penais, quem, embora transitoriamente ou sem remuneração, exerce cargo, emprego ou função pública.

$\S 1^{\circ}$ - Equipara-se a funcionário público quem exerce cargo, emprego ou função em entidade paraestatal, e quem trabalha para empresa prestadora de serviço contratada ou conveniada para a execução de atividade típica da Administração Pública.

$\S 2^{\circ}$ - A pena será aumentada da terça parte quando os autores dos crimes previstos neste Capítulo forem ocupantes de cargos em comissão ou de função de direção ou assessoramento de órgão da administração direta, sociedade de economia mista, empresa pública ou fundação instituída pelo poder público."
} 
Um destaque sobre a equiparação traduzida pelo $\S 1^{\circ}$ é crucial, principalmente em um momento em que a terceirização do serviço público é uma realidade cada vez mais presente, e que cresce vertiginosamente a cada dia. Assim, equipara-se a funcionário público, a título de possibilitar a responsabilização penal, todos aqueles que trabalham "para empresa prestadora de serviço contratada ou conveniada para a execução de atividade típica da Administração Pública”.

O nosso Código Penal trata, com muito rigor, a imoralidade administrativa que ocasione, de alguma forma, prejuízo ao Estado e, por sua vez, ao erário. O legislador penal se preocupou em resguardar o Estado da imoralidade intencional das pessoas, sejam ou não agentes públicos.

Devemos lembrar que o Código Penal data de 1940, e embora nem todos os tipos que visam a tutelar a Administração Pública sejam desta época, a sua grande maioria o é, e nem por isso podemos - infelizmente - afirmar que a prática imoral no interior da Administração Pública tenha sido solucionada e combatida por esta criminalização. Por tais razões é que defendemos a maior eficácia social do tipo de responsabilidade estudada no tópico anterior.

Não queremos com isto defender a descriminalização de tais atos ilegais, imorais e altamente deletérios ao Estado e à sociedade brasileira, o que estamos aqui a fazer é refletir sobre a trazida da saída penal como solução única para um problema tão complexo que é a imoralidade, de uma forma geral, no trato com o dinheiro público. Deve-se aqui afirmar, novamente, que não entendemos se tratar do desvio da finalidade do recurso público, como um problema pessoal deste ou daquele que em dado momento tem o poder de administrar esta verba, mas de um problema social e estrutural, cuja solução está não só na aplicação de sanção para uma determinada pessoa, mas principalmente, que esta deixe de ser uma prática comum nas esferas governamentais.

\subsubsection{Responsabilidade Administrativa}

A responsabilidade administrativa é decorrência do cometimento de ilícito administrativo definido em norma estatutária, o qual apresenta como componentes a ação ou omissão contrária à lei, nexo de causalidade, culpa ou dolo e a existência de dano. 
José Cretella Júnior, em sua obra "Tratado de Direito Administrativo", classificava a responsabilidade administrativa, como sendo responsabilidade civil do Estado por ato do funcionário, advertindo já naquela época que: “O problema da responsabilidade do Estado por ato de seu preposto, neste caso, a pessoa física do agente público, é assunto de grande importância no âmbito do direito público, embora de solução bastante complexa"76.

Para que fique configurada a responsabilidade administrativa, é necessária a instauração de procedimento pela própria Administração, onde são assegurados o contraditório e a ampla defesa ${ }^{77}$.

É certo que os ilícitos administrativos não têm o mesmo rigor descritivo que os ilícitos penais, em regra, são tipos abertos que permitem ampla interpretação. Disto decorre que "a Administração dispõe de certa margem de apreciação no enquadramento da falta dentre os ilícitos previstos na lei, o que não significa possibilidade de decisão arbitrária, já que são previstos critérios a serem observados obrigatoriamente"78, como a natureza e gravidade da infração e os danos causados.

\subsubsection{Comunicabilidade de Instâncias}

Em regra, as responsabilidades são independentes (incomunicabilidade de instância), até pelo princípio da separação de poderes, mas, ocorre que, em determinados casos, o julgado em uma esfera influi decisivamente em outra por força de disposições legais, quais sejam: art. 935, do Código Civil, arts. 65 e 66, do Código de Processo Penal, além de dispositivos nas leis estatutárias dos servidores públicos.

Existem algumas infrações disciplinares dispostas em estatuto que são, ao mesmo tempo, infrações penais, seja porque a infração disciplinar é a prática de crime, seja porque

\footnotetext{
${ }^{76}$ CRETELLA JÚNIOR, José. Tratado de Direito Administrativo. vol. I. São Paulo: Companhia Editora Forense, 1966, p. 117. (itálico original).

77 "Quando a atividade administrativa causa dano a um só que seja dos administrados, está rompido o equilíbrio social e ao direito, que funciona como um termostato, cabe compor o prejuízo sofrido, lançando-se mão dos recursos públicos para os quais concorreu também o próprio cidadão prejudicado". (CRETELLA JÚNIOR, José. Tratado de Direito Administrativo. vol. I. São Paulo: Companhia Editora Forense, 1966, p. 122).

${ }^{78}$ Idem, Ibidem, p. 568.
} 
a mesma ação ou omissão configura crime e infração disciplinar no âmbito administrativo. Outras vezes há que a infração configura apenas infração penal, mas não administrativa ${ }^{79}$.

$\mathrm{Na}$ hipótese de haver infração penal e disciplinar, são instaurados processos administrativo e penal concomitantemente e, segundo o artigo 935, do CC, não mais se poderá questionar sobre a existência de fato ou quem seja seu autor, quando as questões se acharem decididas no juízo criminal. Desta forma, condenado na esfera criminal por fato que configure ilícito penal e administrativo, o juízo cível e a autoridade administrativa, não podem decidir de forma contrária, pois o fato e a autoria já estão devidamente demonstrados ${ }^{80}$.

Se houver absolvição no juízo criminal, haverá que se distinguir seu fundamento segundo os preceitos do artigo 386, do CPP, de forma que, se ficar provada a inexistência do fato (inciso I) ou a existência de circunstância que exclua o crime ou isente o réu de pena (inciso V), bem como se ficar demonstrado não ser o réu o autor do fato (inciso VII), a decisão na esfera administrativa fica vinculada.

Nos casos de não haver prova suficiente da existência do fato (inciso II), da autoria (inciso IV), ou, de maneira mais genérica, de insuficiência de provas para a condenação (inciso VI), ainda poderá sobrevir decisão administrativa condenatória, pois as provas que podem não ser suficientes na esfera penal, podem sê-lo na administrativa.

No caso de absolvição, por não constituir o fato infração penal (inciso III), pode sobrevir decisão administrativa contrária, isto porque a tipicidade da conduta no Direito Penal é muito mais rigorosa que no Direito Administrativo, podendo haver falta residual, conforme a Súmula n. ${ }^{\circ} 18$, do $\mathrm{STF}$, ou seja, conduta que não caracteriza crime, mas que configura ilícito administrativo.

Por fim, o art. 136, da Constituição do Estado de São Paulo dispõe: “O servidor público civil demitido por ato administrativo, se absolvido pela Justiça, na ação referente ao ato que deu causa à demissão, será reintegrado ao serviço público, com todos os direitos adquiridos".

\footnotetext{
${ }^{79}$ Por obvio também é possível que se configure apenas infração disciplinar mas não infração penal.

${ }^{80}$ Idem, Ibidem, p. 571.
} 
Pelo que já foi visto, esta regra não é absoluta. Quando o servidor for absolvido com base nos incisos I, V e VII, do art. 386, do CPP, ele terá direito à reintegração, mas quando o fundamento legal for diverso, em um primeiro momento, nada impede que a Administração Pública puna o servidor.

Com relação à perda do cargo, ocorre sempre que imposta pena de demissão ou demissão a bem do serviço público no âmbito administrativo, mas também pode ocorrer no âmbito penal em duas hipóteses:

- Quando aplicada pena privativa de liberdade por tempo igual ou superior a um ano nos crimes praticados com abuso de poder ou violação de dever para com a Administração Pública;

- Quando for aplicada pena privativa de liberdade por tempo superior a quatro anos nos demais casos.

Se o funcionário não perdeu o cargo na esfera administrativa, fora destas duas hipóteses, não o pode perder por conta de sentença criminal condenatória, ficando afastado do cargo enquanto cumprir pena com o direito de receber parte dos vencimentos ou remuneração. Apesar disto ainda resta a possibilidade de, em crimes em que não há relação com o desempenho das funções inerentes ao cargo do funcionário e em que não há a obrigação de punir por parte da Administração, impor sanção administrativa com base em infração a deveres funcionais expressos de forma genérica, como, por exemplo, "proceder na vida pública e privada na forma que dignifique a função pública" ${ }^{"}$.

${ }^{81}$ Art. 241, XIV, do Estatuto dos Funcionários Públicos Civis do Estado de São Paulo. 


\section{CONCLUSÕES}

A preocupação central deste trabalho, foi analisar os desdobramentos da moralidade administrativa, notadamente no que tange ao manejo dos recursos públicos. Para tanto analisamos dois pontos essenciais: os princípios constitucionais e os mecanismos existentes para exercer o controle sobre os atos estatais.

Esta preocupação descende do fato de que o dinheiro público somente existe, graças ao esforço coletivo da população, que contribui financeiramente com parte significativa de seus salários para prover o Estado. É graças ao povo, e somente a ele, que todos os serviços oferecidos no Executivo, Legislativo e Judiciário estão em funcionamento nos cerca de 5.600 municípios brasileiros.

É o Estado o maior viabilizador social para que a população viva em uma sociedade justa e igualitária, preconizada constitucionalmente. Somente por seu intermédio é que a realidade normativa poderá se aproximar da realidade vivida. E o servidor ou agente público - que age direta ou indiretamente em nome do Estado - tem um papel crucial neste contexto, pois são as decisões e os atos tomados na rotina do seu trabalho que refletirá automaticamente, positiva ou negativamente, na vida de milhares de pessoas. Eis o porquê da importância de que tal agente cumpra a sua função da melhor forma possível e de que aja de acordo com os mais nobres preceitos morais socialmente estabelecidos.

O erário tem no povo o seu legítimo dono, e quando sua utilização é desonestamente realizada, ofende-se não somente ao órgão a que está ligado 
diretamente determinado funcionário, mas a toda a coletividade. É por esta nobre razão que o princípio da moralidade é um norteador inafastável dos atos administrativos.

Em um certo momento da História, foi utilizado como arma para tentar refrear o arbítrio estatal, a lei. Em que pese ser esta uma das maiores marcas da modernidade, não houve condições suficientes de sozinha funcionar a contento, o que levou ao resgate da moral, para contribuir nesta árdua missão.

A reaproximação da moral com o Direito e com a política é, doutrinária e jurisprudencialmente, um grande importuno para a nossa tradição positivista, a qual precisamos urgentemente enfrentar, para que a moralidade no interior do Estado possa realmente ser exigida e controlada em larga escala.

Para tanto, inicialmente, é necessária uma reformulação no modelo do ensino do Direito no Brasil, que se resume atualmente a uma "navegação de cabotagem ao redor dos Códigos", o que torna os profissionais desta área, no geral, desconhecedores da sistemática constitucional, sendo, de certa forma, um empecilho ao controle da moralidade administrativa.

Devemos ainda consignar, que a cobrança social da moralidade não é algo novo, tanto que as lições francesas acerca desta temática, datadas do início do século XX, têm serventia até hoje. Não há porque os operadores do direito sem espantarem com a "subjetividade" ou a "vagueza" do termo.

Aliás, para nós, não se trata de um conceito nada vago, estando, pelo contrário, muito clara a sua incidência, ficando ainda mais evidenciado quando olhamos para a administração da receita tributária. Sendo ela utilizada para cumprir os fins sociais, elencados nas diretrizes, objetivos e metas constitucionais e legais, o seu uso está sendo feito de acordo com os padrões moralmente exigidos. 
Embora se traga esta preocupação com o entendimento da expressão e com a aceitação de seu uso cotidiano, não achamos, obviamente, que somente com isto se garantirá a moralidade na Administração Pública, pois há uma série de outros problemas de ordem cultural e estrutural, que requerem também superação para se poder garanti-la de forma mais ampla.

A primeira e mais essencial crendice popular que precisamos culturalmente desmistificar refere-se à banalização da prática imoral na política. Trata-se de um tremendo desafio esclarecer e se fazer amplamente entender que o Estado, e todos os agentes que estão a ele acoplados, devem se dirigir única e exclusivamente para atender aos interesses da de toda a coletividade; qualquer desvio tem que ser estancado e sanado. Não podemos e não devemos aceitar, frases do tipo, "rouba mas faz" como algo aceitável socialmente.

Entender o desvio de verba como algo que "todo mundo faz" é completamente equivocado, pois esta prática imoral não é marca de todos os agentes estatais, mas somente de uns poucos e maus funcionários, que devem, justamente por isto, serem postos longe da possibilidade de se manejar novamente um recurso público.

Promover o aprimoramento permanente e sistemático dos desajustes sociais é a principal consequencia de um sistema Democrático de Direito. A Democracia é um processo de constante de aperfeiçoamento institucional e social.

Neste sentido, sérios e louváveis avanços foram paulatinamente conquistados, a ponto de hoje podermos acessar de qualquer computador com acesso à internet, a movimentação das contas públicas. Isto que nos parece tão simples em nossos dias, era algo simplesmente impensável a pouquíssimo tempo atrás.

Pelo fato dos ajustes serem constantes, não podemos nos contentar com o que está; assim, muito ainda temos que melhorar, e em relação à prestação de contas públicas não é diferente, devendo ser ainda bastante aprimoradas para que se tornem genuínas merecedoras do certificado da qualidade democrática. O que queremos com isso afirmar é que a radicalização democrática do processo de prestação de contas faz 
vingar frutos que contribuem com a real diminuição das possibilidades de se dar um destino imoral ao tesouro público.

Avanços também podem ser percebidos na instituição dos mecanismos de controle das ações contábil, financeira e orçamentária dos três Poderes. Claro que necessitam de aperfeiçoamento, especialmente para poder desatrelá-los politicamente dos órgãos que têm o papel de controlar, e para buscar a integração na ação dentre todos os mecanismos internos e externos.

Mas, maciçamente em um importante mecanismo de controle externo deve haver especial aprimoramento e investimento: o controle social exercido diretamente pela própria sociedade civil. Pois, quanto maiores as possibilidades de seu mais abrangente exercício, melhor para a Democracia e maiores benefícios serão revertidos socialmente.

Trata-se de um investimento que, dada a sua complexidade, requer trabalhos em diversas frentes, mas em uma delas tem que se dedicar uma atenção incisivamente especial: na educação.

Superar a lógica mercadológica do "meu" e passar a imperar a lógica cidadã do "nosso", é algo que se faz urgentemente necessário se quisermos de fato enfrentar não somente o desvio do dinheiro público, mas a grande maioria dos problemas sociais que somos obrigados a conviver diariamente. Promover a superação do "eu odeio política" para o "devo exercer meu papel de cidadão" é um dos maiores desafios. Para isto um longo caminho precisa ser percorrido.

Entendemos que somente assim estar-se-á viabilizado o ambiente ideal para se estabelecer uma relação permanentemente dialógica entre os cidadãos e a máquina estatal, pois é o povo que sabe onde é que o sistema está falho e no que precisa ser de fato investido, sem desperdícios, para se promover a melhoria das condições de vida, e quiçá um dia, viver em um Estado onde todos os seus atos sejam de fato a materialização da vontade coletiva. 
Quando tais condições estiverem estabelecidas, a tendência será de que a irresponsabilidade na política se rareie cada vez mais, e então poderemos conviver em uma sociedade onde a desigualdade social, seja motivo de espanto, estando bem próximo do que todos almejam. Mas, enquanto isto não acontecer, sigamos controlando eficazmente os desvios e as imoralidades, pois, afinal de contas, devemos proteger o que é nosso.

\section{BIBLIOGRAFIA}

ALEXY, Robert. Teoria de los derechos fundamentales. Tradução de Ernesto Garzón Valdés. Madrid: Centro de Estudios Constitucionales, 1997.

. Derecho y razon práctica. México: Biblioteca de Ética, Filosofia Del

Derecho y Política, 1998.

ALVARENGA, Arístides Junqueira. O Princípio da Moralidade no Direito Tributário. Coordenação Ives Gandra da Silva Martins - conferencista inaugural José Carlos Moreira Alves. São Paulo: Editora Revista dos Tribunais, 1996.

ALTAMIRANO, Alejandro. La discricionalidad administrativa en el procedimento tributario y la motivación del acto administrativo de determinación tributaria. in: SCHOUERI, Luís Eduardo (org.). Direito Tributario - Homenagem a Alcides Jorge Costa. vol. I. São Paulo: Quartier Latin, 2003.

ARAÚJO, Edmir Netto de. Os princípios administrativos na constituição de 1988. São Paulo: Revista da Procuradoria-Geral do Estado de São Paulo, n. ${ }^{\text {34 }} 1990$.

. Curso de Direito Administrativo. $3^{\mathrm{a}}$ ed. São Paulo: Saraiva, 2007. 
ARISTÓTELES. Ética a Nicômacos. Trad. de Mário da Gama Kuri. Brasília: Editora Universidade de Brasília, 1992.

ÁVILA, Humberto. Sistema Constitucional Tributário. $2^{\mathrm{a}}$ ed. São Paulo: Saraiva, 2006. - Teoria dos Princípios da definição à aplicação dos princípios jurídicos. $6^{\text {a }}$ ed. São Paulo: Malheiros, 2006.

BALEEIRO, Aliomar. Uma introdução à Ciência das Finanças. 14 $4^{\mathrm{a}}$ ed. revista e atualizada por Flavio Bauer Novelli. Rio de Janeiro: Forense, 1995.

BANDEIRA DE MELLO, Celso Antônio. Curso de direito administrativo. $14^{\mathrm{a}}$ ed. refundida, ampliada e atualizada até a EC 35. São Paulo: Malheiros Editores, 2002.

BANDEIRA DE MELlO, Oswaldo Aranha. Princípios Gerais de Direito Administrativo. vol. I. Rio de Janeiro: Forense, 1969.

BARROS, Luiz Celso de. Responsabilidade Fiscal e Criminal. Bauru: EDIPRO, 2001.

BASTOS, Celso Ribeiro e Martins, Ives Gandra da Silva Martins. Comentários à Constituição do Brasil: promulgada em 5 de outubro de 1.998. São Paulo: Saraiva, 1.989. . Hermenêutica e Interpretação. $2^{\mathrm{a}}$ ed. São Paulo: Celso Bastos Editor, 1999.

BERLIRI, Antonio. Principi de Diritto Tributario. vol. I. $2^{\mathrm{a}}$ ed. Milano: Giuffre Editore, 1967.

BIELSE, Rafael. Derecho administrativo. Buenos Aires: La Ley, 1965. 
BOBBIO, Norberto. O Positivismo Jurídico. São Paulo: Ícone, 1997.

, Principi generali di Diritto. Novíssimo digesto italiano. Terza Edizione/Vnione Tipográfico - Editrice: Torinese, 1957.

BONAVIDES, Paulo. Curso de Direito Constitucional. 22a ed. atualizada e ampliada. São Paulo: Malheiros, 2008.

BOTTALlO, Eduardo Domingos. Curso de Processo Administrativo Tributário. São Paulo: Malheiros Editores, 2006.

BRANDÃO, José Antonio. Moralidade Administrativa. in Revista de Direito Administrativo, $n .^{\circ} 25$.

BRUNO, Reinaldo Moreira. Lei de Responsabilidade Fiscal \& Orçamento Público Municipal. Curitiba: Juruá, 2003.

CAMMAROSANO, Márcio. O Princípio Constitucional da Moralidade e o Exercício da função Administrativa. Belo Horizonte: Editora Fórum, 2006.

CANOTILHO, José Joaquim Gomes. Direito Constitucional. Coimbra: Livraria Almedina, 1991.

CAVALCANTI, Márcio Novaes. Fundamentos da Lei de Responsabilidade Fiscal. São Paulo: Dialética, 2001.

CERNICCHIARO, Luiz Vicente. O Princípio da Moralidade no Direito Tributário. Coordenação Ives Gandra da Silva Martins - conferencista inaugural José Carlos Moreira Alves. São Paulo: Editora Revista dos Tribunais, 1996.

CITADINI, Antonio Roque. O Controle Externo da Administração Pública. São Paulo: Editora Max Limonad, 1995. 
CONTI, José Maurício. Princípios Tributários da Capacidade Contributiva e da Progressividade. São Paulo: Dialética, 1996.

. Direito Financeiro na Constituição de 1988. São Paulo: Juarez de Oliveira, 1998.

COSTA, Alcides Jorge. Algumas idéias sobre uma reforma do Sistema Tributário Brasileiro. in Direito Tributário Atual. São Paulo: Resenha Tributária, 1988.

CRETELLA JÚNIOR, José. Comentários à constituição de 1988. São Paulo: Forense Universitária, 1991.

. O Estado e a obrigação de indenizar. São Paulo: Saraiva, 1980.

. Tratado de Direito Administrativo. vols. I e II. São Paulo: Forense, 1966.

CRETElla NETO, José. Fundamentos Principiológicos do Processo Civil. Rio de Janeiro: Forense, 2002.

DELGADO, José Augusto. O princípio da moralidade administrativa e a constituição federal de 1988. São Paulo: Revista dos Tribunais, n. ${ }^{\circ}$ 680. 1992.

DI PIETRO, Maria Sylvia Zanella. Direito Administrativo. 20a ed. São Paulo: Atlas, 2007. . Discricionariedade administrativa na constituição de 1988. São Paulo: Atlas, 1991.

DWORKIN, Ronald. Taking rights seriously. Cambridge: Harvard University Press, 1977. 
FERNANDES GÓES, Gisele Santos. Principio da proporcionalidade no processo civil. São Paulo: Saraiva, apud ROJO, Margarita Beladiez. Los princípios jurídicos. Madrid: Tecnos, 1997.

FERRARI, Renato. Em Busca da Paz Tributária. São Paulo: Cia Melhoramentos, 1996.

FERREIRA FILHO, Manoel Gonçalves. A Constituição Brasileira - 1.988 Interpretações. II Fórum Jurídico. Fundação Dom Cabral. Academia Internacional de Direito e Economia. Editora Forense Universitária: Rio de Janeiro.

FIGUEIREDO, Marcelo. O Controle da Moralidade na Constituição. São Paulo: Malheiros, 1.999.

FONROUGE, Carlos M. Giuliani. Derecho Financiero. vols. I e II, 9a ed. Buenos Aires: La Ley, 2004.

FRANCO SOBRINO, Manoel. O Controle da Moralidade Administrativa. São Paulo: Saraiva, 1974.

GARCIA, Emerson. A moralidade administrativa e sua densificação. in Revista de Direito Constitucional e Internacional. n. ${ }^{\circ}$ 43. São Paulo: Editora Revista dos Tribunais, 2003 .

GIACOMUZZI, José Guilherme. A Moralidade Administrativa e a Boa-Fé da Administração Pública. São Paulo: Malheiros Editores, 2002.

. A moralidade administrativa - História de um conceito. in Revista de Direito Administrativo, $n .^{\circ}$ 230, 2002.

GRAU, Eros Roberto. A Ordem Econômica na Constituição de 1988. Interpretação e Crítica. São Paulo: Malheiros, 2003. 
- Equidade, razoabilidade e proporcionalidade e princípio da moralidade. in Revista do Instituto de Hermenêutica Jurídica. vol. I, n. ${ }^{\circ}$ 3, 2005.

GRECO, Marco Aurélio. Notas sobre o Princípio da Moralidade. In SCHOUERI, Luís Eduardo (Org.). Direito tributário: Estudos em Homenagem a Alcides Jorge Costa. Vol. I. São Paulo: Quartier Latin, 2003.

HAURIOU, Maurice. Précis de Droit Administratif et de Droit Public. $11^{\mathrm{a}}$ ed. Paris: Sociéte Anonyme du Recueil Sirey, 1927.

HECK, José. Direito subjetivo e dever jurídico interno em Kant. vol. 48, n. ${ }^{\circ}$ 1, Porto Alegre: Veritas, 2003.

JUSTEN FILHO, Marçal. O princípio da moralidade pública e o direito tributário. Revista Trimestral de Direito Público, n. ${ }^{\circ} 11.1995$.

KANT, Immanuel. A Metafísica dos Costumes. São Paulo: EDIPRO, 2003.

KELSEN, Hans. Teoria Pura do Direito. Tradução de João Baptista Machado. $5^{\mathrm{a}}$ ed. Coimbra: Armênico Amado Editor, 1979.

LARENZ, Karl. Metodologia da ciência do Direito. Tradução de José Lamego. Lisboa: Fundação Calouste Gulbenkian, 1997.

LECCISOTTI, Mario. Istituzioni di scienza delle finanze. 2a ed. Torino: Giapichelli, 2004.

LOPES, Mauricio Antonio Ribeiro. Ética e Administração Pública. São Paulo: Editora Revista dos Tribunais, 1993. 
MARTINS, Ives Gandra da Silva. Estudos sobre o Imposto de Renda. São Paulo: Editora Resenha Tributária, 1994.

MARTINS JÚNIOR, Wallace Paiva. Probidade Administrativa. $4^{\text {a }}$ ed. São Paulo: Saraiva, 2009.

MATA, Márcia Filomena de Oliveira. Fiscalização da administração pública em face da economicidade. in Revista dos Tribunais 710/233.

MEDAUER, Odete. $O$ direito administrativo em evolução. São Paulo: Revista dos Tribunais, 1992.

. Direito administrativo moderno. $11^{\mathrm{a}}$ ed. revista e atualizada. São Paulo:

Editora Revista dos Tribunais, 2007.

MEIRELLES, Hely Lopes. Direito administrativo brasileiro. $33^{\mathrm{a}}$ ed. São Paulo: Malheiros, 2007.

. Mandado de Segurança. 31 a ed. São Paulo: Malheiros Editores, 2008.

MELlO, Cláudio Ari. Fragmentos Teóricos sobre a moralidade administrativa. in Revista de Direito Administrativo $n .^{\circ}$ 25, 2004.

MIRANDA, Jorge. Manual de direito constitucional. $3^{\mathrm{a}}$ ed. t II. Coimbra: Coimbra Editora, 1996.

MORAES, Alexandre de. Direito Constitucional Administrativo. $3^{\mathrm{a}}$ ed. São Paulo: Atlas, 2006. 
. Direitos Humanos Fundamentais - teoria geral, comentários aos arts. $1^{\circ}$ a $5^{\circ}$ da Constituição da República Federativa do Brasil, doutrina e jurisprudência. São Paulo: Atlas, 2003.

MUKAI, Toshio. Administração pública na constituição de 1988. $2^{\mathrm{a}}$ ed. São Paulo: Saraiva, 1989.

NASCIMENTO, Carlos Valder do. Princípios Fundamentais da Legislação Tributária. Bahia: Edições FUSC, 1983.

NOGUEIRA, Ruy Barbosa. Direito Financeiro. São Paulo: José Bushatsky. 1964.

OSÓRIO, Fabio Medina. Improbidade Administrativa. $2^{\mathrm{a}}$ ed. Porto Alegre: Editora Síntese, 1998.

PEREIRA JUNIOR, José Torres. Da reforma administrativa constitucional. Rio de Janeiro: Editora Renovar, 1999.

PEREZ LUÑO, Antonio. Los Derechos Fundamentales. Madrid: Tecnos, 1988.

PONTES, Helenilson Cunha. O Princípio da Proporcionalidade e o Direito Tributário. São Paulo: Dialética. 2000.

RAWLS, John. A Theory of Justice. $2^{\text {a }}$ ed. Cambridge: Harvard University, 1999.

REALE, Miguel. Aplicações da Constituição de 1988. Rio de Janeiro: Forense, 1990. . Filosofia do Direito. vol. I, $5^{\text {a }}$ ed. São Paulo: Saraiva, 1969.

ROCHA, Cármen Lúcia Antunes. Princípio Constitucional da administração pública. Belo Horizonte: Del Rey, 1994. 
ROTHMANN, Gerd Willi. Considerações sobre Extensão e Limites do Poder de Tributar. in Estudos Tributários - coordenação de Ruy Barbosa Nogueira. São Paulo: Resenha Tributária, 1974.

O Princípio da Legalidade Tributária. São Paulo: Revista da Faculdade de Direito da USP, 1972.

ROTHMANN, Gerd Willi, PACIELLO, Gaetano. Elisão e Evasão Fiscal. in Caderno de Pesquisas Tributárias, n. ${ }^{\circ} 13$ - coordenação de Ives Gandra da Silva Martins. São Paulo: Resenha Tributária, 1988.

RUBINSTEIN, Flávio. Boa-fé objetiva no Direito Financeiro e Tributário. Séria Doutrina Tributária, vol. III. São Paulo: Quartier Latin, 2010.

SACCHETTO, Cláudio. Ética e Tributação. Tradução de Flavio Rubinstein. in. Revista de Direito Tributário Atual, vol. 20, 2006.

SCHOUERI, Luís Eduardo. Contribuição ao Estudo do Regime Jurídico das Normas Tributárias Indutoras como Instrumento de Intervenção sobre o Domínio Econômico. São Paulo: USP, 2002.

SILVA, José Afonso da. Curso de Direito Constitucional Positivo. $28^{\mathrm{a}}$ ed. São Paulo Malheiros Editores, 2006.

. Comentário contextual à Constituição. $3^{\mathrm{a}}$ ed. São Paulo: Malheiros

Editores, 2007.

TEMER, Michel. Elementos de direito constitucional. $19^{\mathrm{a}}$ ed. São Paulo: Malheiros Editores, 2003.

TIPKE, Klaus. Moral Tributaria del Estado y de los contribuintes. Tradução de Pedro Herrera Molina. Madrid: Marcial Pons, 2002. 
. e YAMASHITA, Douglas. Justiça Fiscal e Princípio da Capacidade

Contributiva. São Paulo: Malheiros, 2002.

TORRES, Ricardo Lobo. O orçamento na Constituição. Rio de Janeiro: Renovar, 1995.

: Princípio da Eficiência em Matéria Tributária. Coordenação Ives

Gandra da Silva Martins - conferencista inaugural José Carlos Moreira Alves. São Paulo:

Revista dos Tribunais, 2006.

. Tratado de Direito Constitucional Financeiro e Tributário. Rio de

Janeiro: Renovar, 1999.

UCKMAR, Victor. Princípios comuns de direito constitucional tributário. Tradução de Marco Aurélio Greco. São Paulo: Editora Revista dos Tribunais, 1976.

WEBER, Max. Economia e Sociedade. vols. I e II. Brasília: UNB, 1999.

WELTER, Henri. Le Controle jurisdictionnel de la Moralité Administrative - Éstude de Doctrine et de jurisprudence. Paris: Recueil Sirey, 1929.

WIEACKER, Franz. Principio general de la buena fé. Tradução de José Luis Carro. Madrid: Civitas, 1977. 